\author{
UNIVERSIDADE DE SÃO PAULO \\ ESCOLA DE COMUNICAÇÕES E ARTES \\ DEPARTAMENTO DE MÚSICA
}

VALÉRIA MUELAS BONAFÉ

\title{
Estratégias composicionais de Luciano Berio a partir de uma análise da Sonata per pianoforte (2001)
}

\begin{abstract}
Dissertação apresentada ao Programa de Pósgraduação em Música, Área de Concentração Musicologia, Linha de Pesquisa História, Estilo e Recepção, da Escola de Comunicações e Artes da Universidade de São Paulo, como exigência parcial para obtenção do título de Mestre em Música, sob orientação do Prof. Dr. Marcos Branda Lacerda.
\end{abstract}


Autorizo a reprodução e divulgação total ou parcial deste trabalho, por qualquer meio convencional ou eletrônico, para fins de estudo e pesquisa desde que citada a fonte.

\section{Catalogação na publicação \\ Serviço de Biblioteca e Documentação \\ Escola de Comunicações e Artes da Universidade de São Paulo}

Bonafé, Valéria Muelas

Estratégias composicionais de Luciano Berio a partir de uma análise da Sonata per pianoforte (2001) / Valéria Muelas Bonafé - São Paulo : V.M. Bonafé, 2011.

147 p. : il. + CD

Dissertação (Mestrado) - Escola de Comunicações e Artes / Universidade de São Paulo.

Orientador: Prof. Dr. Marcos Branda Lacerda

1. Análise musical 2. Obra aberta 3. Reescritura 4. Gesto 5. Processo 6. Sonata per pianoforte (peça musical) 7. Interlinea per pianoforte (peça musical) 8. Berio, Luciano, 1925-2003 I. Lacerda, Marcos Branda II. Título

CDD 21.ed. -780.945092 
Nome: BONAFÉ, Valéria Muelas

Título: Estratégias composicionais de Luciano Berio a partir de uma análise da Sonata per pianoforte (2001)

Dissertação apresentada ao Programa de Pósgraduação em Música, Área de Concentração Musicologia, Linha de Pesquisa História, Estilo e Recepção, da Escola de Comunicações e Artes da Universidade de São Paulo, como exigência parcial para obtenção do título de Mestre em Música, sob orientação do Prof. Dr. Marcos Branda Lacerda.

São Paulo, de de 2011.

Banca Examinadora

Prof. Dr.

Instituição:

Julgamento:

Assinatura

Prof. Dr.

Instituição:

Julgamento:

Assinatura

Prof. Dr.

Instituição:

Julgamento: Assinatura 
Para Rogério, por nós 


\section{AGRADECIMENTOS}

Ao Marcos, que me orientou com todo o cuidado nessa pesquisa, por seu respeito, generosidade e paciência.

Ao Rogério, por sua inestimável contribuição com leituras, críticas e traduções, e por acolher meus inúmeros melindres.

Ao meu pai, Hermínio, que me inspira a serenidade, e à minha mãe, Yolanda, que me inspira a guerrilha, pelo suporte e incentivo aos estudos, sempre.

À Daniela, minha irmã, por seu companheirismo e por sua cumplicidade.

À Isadora, por compartilhar comigo seu universo lúdico e intenso, e por me lembrar que há coisas mais valiosas do que a intelecção.

Ao Zeca, que esteve literalmente ao meu lado durante a redação desse trabalho e que me convidou a caminhar diariamente, por sua incessante alegria e amor incondicional.

Ao Silvio, cujo trabalho criativo me comove, por me contaminar com sua paixão pela composição.

Aos amigos Enrique, Gustavo, Felipe e André, por sua parceria.

Ao Prof. Dr. Paulo de Tarso Salles por suas contribuições no exame de qualificação.

À Tania Lanfer Marques, Martin Herraiz e Leonardo Aldrovandi por sua ajuda com materiais utilizados nesse trabalho.

À Fundação de Amparo à Pesquisa do Estado de São Paulo, pela concessão da bolsa de mestrado e pelo apoio financeiro essencial para a realização desta pesquisa. 


\section{RESUMO}

A Sonata per pianoforte, composta em 2001, é o trabalho para piano solo de maior fôlego de Luciano Berio. A peça condensa diversas estratégias composicionais características de Berio e se apresenta, assim, como uma espécie de relicário da escritura desse compositor. Nesse trabalho comentaremos, a partir da Sonata, três importantes estratégias composicionais de Luciano Berio: a noção de reescritura, a noção de gesto e a noção de processo. Como veremos, essas três noções são atravessadas pela idéia de obra aberta e estarão presentes durante todo seu percurso composicional, consolidando-se como aspectos fundamentais para a construção de sua poética.

Palavras-chave: Análise musical, Luciano Berio, Sonata per pianoforte (2001), Interlinea per pianoforte (2000), Obra aberta, Reescritura, Gesto, Processo. 


\begin{abstract}
The Sonata per pianoforte, composed in 2001, is the Luciano Berio's solo piano work of greatest scope. The piece brings together several of Berios's characteristic compositional strategies and thus presents itself as a sort of a reliquary of his musical resources. In this work, we will comment, from the Sonata, three Luciano Berio's important compositional strategies: the notion of rewriting (réécriture), the notion of gesture and the notion of process. As we will see, these three notions are crossed by the idea of open work and will be present throughout his compositional pathway, establishing themselves as fundamental aspects for the construction of his poetry.
\end{abstract}

Keywords: Musical Analysis, Luciano Berio, Sonata per pianoforte (2001), Interlinea per pianoforte (2000), Open work, Rewriting (réécriture), Gesture, Process. 


\section{LISTA DE FIGURAS}

Fig. 01 Possibilidades de montagem para Epifanie ................................................ 21

Fig. 02 Quadro Comparativo A: correlações diretas entre a Sonata e Interlinea ........... 35

Fig. 03 Quadro Comparativo B: correlações diretas entre Sonata e Interlinea ............. 35

Fig. 04 Trecho original de Interlinea (c.8 a c.12) e citação do mesmo trecho dentro da Sonata (c.72 a c.75) ......................................................................... 37

Fig. 05 Comparação do material harmônico de um trecho original de Interlinea com seu correspondente reescrito na Sonata através do processo de citação .......... 38

Fig. 06 Trecho original de Interlinea, c.13 a c.19 ..................................................... 39

Fig. 07 Expansão de Interlinea dentro da Sonata, c.79 a c.89 ..................................... 40

Fig. 08 Sonogramas de Interlinea (vermelho), c.13 a c.19, e Sonata (azul), c. 79 a c. 89

Fig. 09 Trecho original de Interlinea, c.01 a c.07 (no centro da figura), e derivação desse trecho dentro da Sonata, c.65 a c.71

Fig. 10 Transcrição de um trecho do rascunho da Sonata de Berio realizada por Brinkmann ....

Relação entre cores e gestos

Fig. 12

Gesto Z em c. 1 a c. 3

Fig. 13 Compassos inicias de Le Gibet (1908), em Gaspard de la Nuit, para piano, de Maurice Ravel

Fig. 14

Gesto A em c. 3 e c. 4

Fig. 15

Gesto A na Sequenza $I V$, c. 1 a c. 5 .

Fig. 16

Gesto A em Leaf, c. 1 a c.6

Fig. 17

Gesto B em c.6, c. 8 e c. 13

Fig. 18

Gesto C em c. 12

Fig. 19

Gesto C em c. 18

Fig. 20

Gesto C em c. 21

Fig. 21

Gesto D em c.14

Fig. 22

Gesto E em c.15 e 16

Fig. 23

Gesto F em c.79

Fig. 24

Origem dos Gestos D, E e F. Interlinea, c.13 ..

Fig. 25

Fig. 26

Gesto D em "Points on a curve do find...", c.2

Fig. 27

Gestos E e F em Luftklavier, (peça sem compassos)

66

Fig. 28

Gesto $\mathrm{G}$ em c. 26 , c. 27 e c. 28

66

Fig. 29 Análise do esquema de distribuição dos gestos no início da Sonata, c. 1 a c. 28

Fig. 30

Características rítmicas dos gestos mapeados

Fig. 31 Gestos com figuras rítmicas regulares: Z, D, E, F e G ................................. 74

Fig. 32 Gestos com figuras rítmicas variadas: A, B e C …....................................... 75

Fig. 33 Gesto Z com alterações rítmicas: uso do compasso 7/8, em c.22-23 ............... 75

Fig. 34 Gesto E: sobreposição de dois ciclos melódicos, em c.153 a c.155: com notas rebatidas (vermelho) e com movimentação livre (marrom)

Fig. 35 Gesto E: sobreposição de dois ciclos melódicos, em c.153 a c.155: com notas rebatidas (vermelho) e com movimentação livre (marrom) ................... 78

Fig. 36 Gesto A, c.3 a c.5

Fig. 37 Complementaridade cromática e manutenção de notas comuns (vermelho) nos seis primeiros acordes da Sonata, c. 3 a c.5

Fig. 38 Conjunto de alturas que compõem o gesto $\mathrm{E}$ em c.15, c.40, c.55 e c.76 .......... 84 
Fig. 39 Modelo I: acordes com estrutura em 3m e 3M nos gestos C, A e B, respectivamente

Fig. 40 Proliferação de terças através do gesto $\mathrm{F}$

Fig. 41 Modelo II: acordes com estrutura em 2M e 3M (tons inteiros) nos gestos A, $\mathrm{C}$ e $\mathrm{B}$, respectivamente

Fig. 42 Modelo III: acordes com estrutura em quartas nos gestos B, C e A, respectivamente

Fig. 43 Modelos I, II e III agrupados no gesto C, em c.12 ….................................... 88

Fig. 44 Série de alturas e seus respectivos valores, em Nones ...................................... 92

Fig. 45 Série de durações e seus respectivos valores, em Nones ................................... 92

Fig. 46 Série de intensidades e seus respectivos valores, em Nones ............................ 93

Fig. 47 Série de articulações e seus respectivos valores, em Nones ............................. 93

Fig. 48 Trecho inicial de Variazione I, em Cinque Variazioni ...................................... 95

Fig. 49 Série de doze notas apresentada no início de Variazione I, em Cinque

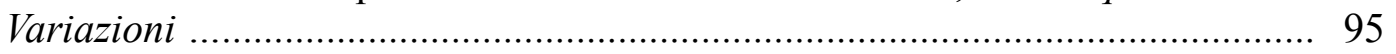

Fig. 50 Série de treze notas em forma de palíndromo $(\mathrm{R} 0=\mathrm{P} 6)$, em Nones ................. 96

Fig. 51 Tricordes gerados pela série de treze notas compondo o conjunto (014), em Nones

Fig. 52 (A/Z): sobreposição dos gestos A e Z , c.1 a c.5 ...

Fig. $53(\mathrm{~A} / \mathrm{Z}),(\mathrm{B} / \mathrm{Z})$ e $(\mathrm{ZxC})$ : sobreposição entre os gestos $\mathrm{Z}$ e $\mathrm{A}, \mathrm{Z}$ e B, e modulação entre os gestos $\mathrm{Z}$ e $\mathrm{C}$.

Fig. 54 (FxZ): modulação entre os gestos F e Z, c.89 ................................................. 104

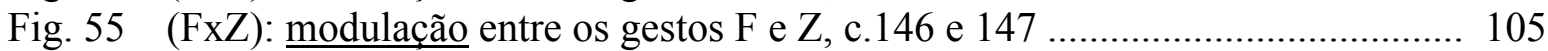

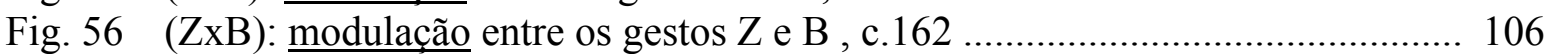

Fig. 57 Gesto A em forma de cluster em c.19 de Interlinea e em c.88 da Sonata ......... 107

Fig. 58 (A+B): agrupamentos entre os gestos A e B ............................................... 108

Fig. 59 (BxZ): modulação entre os gestos B e Z, c.186 ................................................ 109

Fig. 60 Construção harmônica conduzida pelo gesto B entre c.197 e c.215 ................... 109

Fig. $61(\mathrm{~A}+\mathrm{B})$ e (BxZ): agrupamento dos gestos $\mathrm{A}$ e $\mathrm{B}$ e modulação dos gestos B e Z, c.216 a c.218 ............................................................................. 110

Fig. 62 (E-C - E): transição entre o gestos E e C, c.137 a c.145 ................................ 111

Fig. 63 Transformações do gesto D: justaposição em c.56 e sobreposição em c. 128

Fig. 64 Diferentes figuras do gesto E: âmbito compacto em c.55 e âmbito expandido



Fig. 65 Gesto E com adensamento da textura, em c.148 e c.149 ................................. 114

Fig. 66 Todas as aparições do gesto F: notas e quantidade de ataques ......................... 115

Fig. 67 (D+E+F): agrupamento dos gesto D, E e F, c.79 ......................................... 116

Fig. $68[(\mathrm{D}+\mathrm{E}+\mathrm{F}) / \mathrm{G}]$ : agrupamento dos gestos $\mathrm{D}, \mathrm{E}$ e F, e sobreposição desse agrupamento ao gesto $\mathrm{G}, \mathrm{c} .118$ a c. 120

Fig. $69[(\mathrm{E}+\mathrm{F}) / \mathrm{G}]$ : agrupamento dos gestos $\mathrm{E}$ e $\mathrm{F}$ e sobreposição desse grupo ao

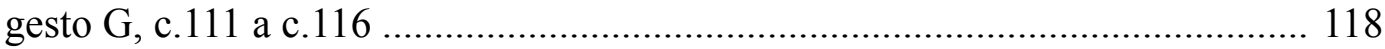

Fig. 70 (GxB): modulação entre os gestos G e B, c.242 a c.244 …............................. 119

Fig. 71 Diagrama de tendências e conexões mais comuns entre os oito gestos mapeados

Fig. 72a Mapa Formal (parte 1/2) ............................................................................. 127

Fig. 72b Mapa Formal (parte 2/2) ........................................................................... 128 


\section{SUMÁRIO}

introdução 12

capítulo I. obra aberta 18

capítulo II. reescritura

IIa. sobre a noção de reescritura em Berio 27

IIb. reescritura na Sonata 33

capítulo III. gesto

IIIa. sobre a noção de gesto em Berio 47

IIIb. gesto na Sonata 55

capítulo IV. construção rítmica e harmônica

IVa. ritmo 73

IVb. harmonia 80

capítulo V. processo

Va. sobre a noção de processo em Berio 91

Vb. processo na Sonata: os gestos em movimento 101

capítulo VI. forma 124

considerações finais 135

bibliografia 140

anexos 147

anexo A. Sonata per pianoforte (2001) - partitura

anexo B. Interlinea per pianoforte (2000) - partitura

anexo C. Sonata (2001) e Interlinea (2000) - gravações (CD) 
introdução 


\section{introdução}

A escritura para piano esteve presente ao longo de toda a produção de Berio que inclui, além de diversas peças solo, um concerto para piano e grupo instrumental, um concerto para dois pianos e orquestra, e uma grande variedade de formações camerísticas com piano. O conjunto de composições para piano de Berio inclui peças desde a Petite Suite, de 1947 - escrita no contexto de seus estudos no Conservatório de Milão - até a Sonata, de 2001 - sua última composição para piano. De acordo com sua cronologia de obras $^{1}$, seu segundo trabalho para piano é Cinque Variazioni, composta em 1953, que evidencia forte influência de Dallapiccola. Já na década de 60, Berio escreve a Sequenza IV (1966) e Rounds (1967), ambas também para piano solo. A década de 70 é marcada por trabalhos de maior dimensão, como o Concerto para dois pianos e orquestra (1972-73) e "Points on a curve to find..." (1974) para piano e 22 instrumentos. No fim da década de 80 Berio dedica um segundo concerto ao piano, o Concerto II "Echoing curves" (1988-89), para piano solo acompanhado de dois grupos instrumentais. Data de 1990 a publicação de Six Encore, um conjunto de seis peças curtas para piano solo escritas em diferentes momentos da

1. Tomamos por referência os catálogos de publicação das editoras Suvini Zerboni e da Universal Edition, a cronologia de obras apresentada por OSMOND-SMITH em Berio (1991), e a base de dados do CENTRO STUDI. 
trajetória de Berio: Brin (1990), Leaf (1990), Wasserklavier (1965), Erdenklavier (1969), Luftklavier (1985) e Feuerklavier (1989). No ano seguinte à publicação de Six Encores Berio compõe Touch e Canzonetta, ambas para piano a quatro mãos, ainda sem publicação impressa $^{2}$. Finalmente, no ano 2000, Berio escreve Interlinea e, em 2001, a Sonata per pianoforte, seu último trabalho para piano solo.

A Sonata foi estreada em $1^{\circ}$ de julho de 2001, durante o Zürich Festival, pelo pianista Andrea Lucchesini, colaborador de Berio de longa data, que já havia realizado em 1991 a première do Concerto II "Echoing curves" em Londres. Segundo Reinhold Brinkmann $^{3}$, após a estréia, Berio teria feito ainda uma última revisão da Sonata modificando principalmente a ordem das seções. A versão final da peça teria sido concluída em 12 de julho de 2001. Como muitas outra peças de Berio, a Sonata tem suas raízes em um trabalho anterior, no caso, na peça Interlinea, também para piano solo, escrita um ano antes da Sonata por ocasião de um concerto comemorativo ao $75^{\circ}$ aniversário de Pierre Boulez.

Apesar de ser sua peça para piano solo de maior fôlego, com cerca de 25 minutos de duração ${ }^{4}$, a Sonata parece ainda não ter alcançado tanta notoriedade quanto a Sequenza $\mathrm{IV}$, sua peça pra piano mais executada e comentada. No início de 2001, em correspondência enviada a Reinhold Brinkmann, Berio afirmava: "Eu tenho estado muito ocupado tentando finalizar a tempo um trabalho para piano de grandes proporções e quase impossível de tocar" (BERIO, 2001 apud BRINKMANN, 2005, p. 481)5. Provavelmente devido sua complexidade e dificuldade técnica, atualmente há somente duas gravações comerciais da peça e muito poucas referências bibliográficas. Porém, como veremos, a Sonata condensa uma série de estratégias composicionais características de Berio e se apresenta, assim, como uma espécie de relicário da escritura do compositor. Em nosso trabalho comentaremos, a partir da Sonata, três aspectos composicionais centrais na produção de Berio: a noção de reescritura, a noção de gesto e a noção de processo. Essas três noções estarão presentes durante todo seu percurso composicional, consolidando-se como aspectos fundamentais para a constituição de sua poética. Em nosso trabalho, mostraremos também como as noções de reescritura, gesto e processo são atravessadas por um mesmo conceito, a saber, o de obra aberta.

2. Apesar das partituras não terem sido ainda publicadas, as duas peças foram gravadas por Andrea Lucchesini no CD Berio: Piano Music, 2007.

3. Musicólogo alemão amigo de Berio a quem a Sonata é dedicada.

4. A primeira gravação da peça, realizada por Francesco Tristano Schlimé (Sisyphe, 2005) tem duração de 28'15". A segunda gravação, realizada por Andrea Lucchesini (Avie Records, 2007), tem duração de 23'20".

5. "I have been very busy, trying to finish on time a huge and almost unplayable piano work". 
O Capítulo I será dedicado à noção de obra aberta. Nesse capítulo realizaremos um breve comentário a respeito de algumas ressonâncias da poética de James Joyce na obra de Berio para introduzir o surgimento da idéia de obra aberta em suas composições a partir da década de 50. Dentro dessa perspectiva, trabalharemos principalmente com dois textos: Obra Aberta: forma e indeterminação nas poéticas contemporâneas, de Umberto Eco, e $O$ Alter Duft, do próprio Berio. O livro Obra Aberta, de Umberto Eco, é um conjunto de ensaios escritos no fim da década de 50 e publicados pela primeira vez em 1962. Nesses ensaios, que também manifestam grande influência de Joyce, Eco discute e formaliza o conceito de obra aberta a partir do estudo de algumas poéticas contemporâneas, em especial, nas áreas de literatura e música. Já $O$ Alter Duft é a transcrição de uma das seis conferências proferidas por Berio na renomada série The Charles Eliot Norton Lectures, na Universidade de Harvard, durante o ano letivo de 1993-94. Tais conferências foram publicadas pela primeira vez em inglês, em 2006, sob o título Remembering the future. A quarta conferência, O Alter Duft, é dedicada exclusivamente ao comentário da noção de obra aberta, evidenciando a importância de tal referência para uma leitura da poética de Berio. Além de ser seu texto mais extenso sobre o assunto, o interesse em trabalhar especialmente com O Alter Duft é que ele foi elaborado no início da década de 90, cerca de quarenta anos após o auge da idéia de obra aberta tanto na literatura quanto na música, expondo uma visão crítica de Berio sobre o assunto. Nesse capítulo, a critério de exemplo, faremos um breve comentário sobre a Sequenza I (1958) e Epifanie (1961). Como veremos, a noção de abertura estará implicada nas três estratégias composicionais que trataremos nos capítulos seguintes: reescritura, gesto e processo.

O Capítulo II será dedicado à idéia de reescritura em Berio. Nesse capítulo partiremos do texto Translating Music que, assim como O Alter Duft, compõe a série de conferências que Berio apresentou em Harvard. Nesse texto, Berio comenta a importância da transcrição musical ao longo da história da música e também dentro de sua própria poética. Porém, veremos que sua idéia de transcrição aparece modulada pelo viés composicional, o que conduzirá nossa leitura à idéia de reescritura. A critério de exemplo faremos um breve comentário sobre a relação entre as Sequenze e os Chemins, mais especificamente, sobre o conjunto de peças composto por Sequenza VI (1967), Chemins II (1967), Chemins IIb (1970), Chemins IIC (1972) e Chemins III (1968). Num segundo momento, observaremos como a idéia de reescritura está presente na Sonata através da sua relação com Interlinea, também 
para piano, escrita um ano antes. A partir de uma análise comparativa verificaremos as semelhanças e diferenças entre as duas peças. Nesse contexto, exemplificaremos quatro diferentes maneiras de aproveitamento do material de Interlinea dentro da Sonata: citação, expansão, derivação e proliferação.

O Capítulo III será dedicado à noção de gesto em Berio. A noção de gesto é formalizada por Berio no ensaio intitulado Du geste et de Piazza Carità (1983a) ${ }^{6}$, escrito em 1961, a partir do qual cercaremos a categoria de gesto dentro do campo composicional. De maneira complementar, nos utilizaremos também das idéias de gesto, figura e textura apresentada por Brian Ferneyhough no artigo Il Tempo della figura (1993a). Apesar de terem sido escritos em momentos diferentes, respondendo a problemas composicionais específicos de cada época, verificaremos como os textos de Berio e Ferneyhough são complementares, na medida em que constroem uma noção de gesto própria ao campo da composição. Tendo estabelecido nossas premissas para utilização da noção de gesto passaremos a um trabalho de identificação e caracterização dos gestos presentes na Sonata, criando um mapa gestual da peça.

No Capítulo IV destacaremos alguns aspectos relevantes da construção rítmica e harmônica da Sonata, observando de maneira sintética o que podemos chamar de "o detalhe do gesto", isto é, algumas de suas características figurais. Através da análise, delimitaremos algumas constantes no que se refere à organização rítmica e harmônica da peça mapeando, assim, certos procedimentos típicos da escrita de Berio.

O Capítulo $\mathbf{V}$ será dedicado à noção de processo. A idéia de processo surge na obra de Berio com a composição de Nones (1954), para orquestra, que será comentada de maneira sintética junto com Cinque Variazioni (1952-3), para piano. Também faremos uma aproximação entre a idéia de processo e a noção de figura. Num segundo momento, observaremos a idéia de processo dentro da Sonata, verificando a história energética de cada um dos gestos iniciais mapeados no capítulo anterior, isto é, a maneira como cada um deles se desenrola ao longo da peça. Nesse momento, estaremos tratando da movimentação figural de cada gesto. Em nossa análise, os gestos serão colocados em relação uns aos outros, mostrando as interferências e as deformações resultantes dos choques e curtos-circuitos entre eles. Através de modificações figurais mais acentuadas, veremos ainda como alguns dos gestos

6. O texto foi publicado originalmente em La Musique et ses problèmes contemporains, Cahiers Renaud-Barrault $\mathrm{n}^{\circ} 41$ (1963), pp. 216-223. Em nosso trabalho usaremos a segunda publicação do texto em: Contrechamps n ${ }^{\circ}$ (1983a), pp. 41-45. Há ainda uma versão italiana do texto publicada em: Sequenze per Luciano Berio. Milano: Ricordi 2000, pp. 275-27. 
iniciais originam novas figuras. Nessa análise poderemos verificar como o caráter processual da noção de gesto opera efetivamente dentro da Sonata.

No Capítulo VI, construiremos um mapa de estruturação formal de toda a peça a partir das análises realizadas nos capítulos anteriores. Nesse contexto, comentaremos como se constituem diferentes partes, seções e subseções dentro da Sonata, levando em conta aspectos relativos às estratégias de reescritura, gesto e processo.

Nas Considerações Finais recuperaremos de maneira sintética os assuntos tratados nos capítulos anteriores e concluiremos o trabalho apontando para uma possível leitura a respeito da forma musical implicada na Sonata. 
capítulo I - obra aberta 


\section{obra aberta}

Em muitos dos seus textos, o pesquisador David OsmondSmith destaca a influência de James Joyce no pensamento composicional de Berio. O contato com os textos Joyce se manifesta pela primeira vez na obra de Berio na década de 50, com a peça Chamber Music (1953), para voz feminina e grupo de câmara, onde Berio utiliza três poemas retirados de um livro homônimo de Joyce, publicado em 1907. Na segunda metade da década de 50, no contexto de suas atividades junto ao Studio di Fonologia Musicale (RAIMilão), Berio conhece Umberto Eco, com quem aprofunda os estudos de alguns textos de Joyce, em especial, Ulysses. Como resultado, em 1958, Berio escreve Thema (Omaggio a Joyce), para tape, a partir da leitura do início capítulo XI de Ulysses, intitulado Sereias, realizada por Cathy Beberian. Outros fragmentos de Joyce também estarão presentes em peças posteriores, como Epifanie (1959-61) ${ }^{7}$ e Sinfonia (1968-69). Porém, Osmond-Smith (1983, p. 84) aponta que a relação de Berio com a obra de Joyce é multifacetada e que vai além da utilização de seus textos dentro de algumas composições. Em três estudos diferentes, Osmond-Smith expõe com maior detalhe alguns paralelos entre a obra de Berio e a de Joyce (especialmente Finnegans Wake). Em Joyce, Berio e l'art de l'explosition (1983), Osmond-

7. Revisada em 1965 e reescrita pelo próprio Berio em 1991. 
Smith relaciona o processo de criação de Finnegans Wake ao trabalho realizado por Berio com as Sequenze e com os Chemins, a partir da idéia de work in progress. Já em seu livro Playing on Words: a Guide to Luciano Berio's Sinfonia (1985a), Osmond-Smith faz uma aproximação entre o processo de escrita de Finnegans Wake e o processo de composição da Sinfonia, na medida em que as duas obras seriam o resultado de um trabalho de sobreposição de camadas e de articulação simultânea de diferentes níveis de associação. Finalmente, no artigo Here comes nobody (2000), Osmond-Smith faz uma análise de Outis (1995-96), uma espécie de teatro musical de Berio inspirado em Ulysses, destacando semelhanças com relação à estrutura formal de Finnegans Wake na medida em que também dispensa uma narrativa linear, sendo construída através de uma rede associativa de imagens.

A influência de Joyce marcou não somente a produção de Berio mas o pensamento de toda uma geração de compositores, tendo desdobramentos de grande impacto na reflexão a respeito da forma musical a partir dos anos 50. Nesse contexto, ganha força entre os compositores reunidos em torno dos cursos de Darmstadt - especialmente Berio, Boulez, Stockhausen e Pousseur - a noção de obra aberta, posteriormente discutida e formalizada por Umberto Eco em seu livro Obra Aberta: forma e indeterminação nas poéticas contemporâneas. Esse livro é uma coletânea de ensaios escritos no fim da década de 50 e publicados pela primeira vez em 1962. No primeiro artigo do livro, intitulado A poética da obra aberta, Umberto Eco parte justamente de um comentário a respeito das músicas escritas pelos compositores de Darmstadt em anos precedentes para estruturar o conceito de obra $a b e r t{ }^{8}$. A relação entre a poética de Joyce e a idéia de obra aberta também é evidenciada por Umberto Eco na introdução do seu livro, onde comenta que parte dos ensaios que compõem a Obra Aberta havia sido apresentada originalmente em uma comunicação durante o XII Congresso Internacional de Filosofia, em 1958, e que, naquela ocasião, tais ensaios haviam sido sucedidos por um estudo da poética de Joyce que, segundo Eco, manifesta o projeto de obra aberta com máxima transparência ${ }^{9}$.

8. É relevante destacar a importância da relação de Umberto Eco com os compositores de Darmstadt nesse período, principalmente com Luciano Berio, com quem estabeleceu grande amizade. A relação entre Umberto Eco e Berio foi marcada por um constante jogo de influência mútua. Umberto Eco introduziu Berio a um estudo mais detalhado dos textos e das idéias poéticas de Joyce, ao passo que o contato com a obra de Berio foi essencial para Umberto Eco elaborar a noção de obra aberta. Em entrevista a Bálint András Varga, Berio afirma: "Eu o introduzi à linguística e ele me introduziu a Joyce" (OSMOND-SMITH, 1985b, p. 142) / ["I introduced him to linguistics and he introduced me to Joyce"]. Em contrapartida, no prefácio de seu livro Obra Aberta, Umberto Eco afirma: "as pesquisas sobre a obra aberta tiveram início quando acompanhava as experiências musicais de Luciano Berio e discutia os problemas da musica nova com ele, Henri Pousseur e André Boucourechliev" (ECO, 1976, p. 36).

9. Um pouco mais adiante, Eco (1976, p. 47) afirmará: "É supérfluo lembrar aqui ao leitor, como exemplo 
No início do seu livro, Umberto Eco (1976, p. 40) afirma que, em última instância, todas as obras de arte são, de certa maneira, abertas, na medida em que podem ser compreendidas segundo múltiplas perspectivas por parte dos ouvintes. Porém, no decorrer dos seus ensaios, Eco mostrará como o projeto de obra aberta é privilegiado especialmente nas poéticas contemporâneas. Para Eco, haveria uma potencialização da idéia de abertura na produção artística do século XX, em especial a partir dos anos 50, passando a se manifestar de maneira menos metafórica e mais explícita, sob parâmetros mais concretos. Outro ponto importante para Eco é que a abertura de uma obra passa a se dar em diferentes níveis, isto é, na sua construção, interpretação e/ou recepção. Para Eco, o projeto de obra aberta é bastante claro e palpável, por exemplo, em peças como Sequenza I (1958), para flauta (em sua primeira versão), Klavierstück XI (1956) de Stockhausen, Scambi (1957) de Henri Pousseur, ou ainda na Terceira Sonata para Piano (1955-57) de Boulez, todas escritas no mesmo período. Nessas peças, há um menor ou maior grau de abertura que varia de acordo com o tipo e com a quantidade de escolhas que o compositor deixa a critério do intérprete. $\mathrm{Na}$ Sequenza I, por exemplo, as alturas, intensidades e articulações estão precisamente definidas. Porém, as durações aparecem grafadas em notação proporcional, permitindo uma maior flexibilidade do intérprete principalmente para executar passagens mais rápidas e de maior dificuldade técnica. Apesar da notação proporcional e da não utilização de barras de compasso, Berio insere pequenos traços na partitura que demarcam o espaço que corresponde a constante pulsação do metrônomo, fixado em 70bpm. Dessa maneira, há uma esperada variação rítmica entre diferentes interpretações, sem que sejam extremamente divergentes. ${ }^{10}$

Uma outra forma de abertura - essa sim atribuindo intencionalmente uma maior liberdade ao intérprete - foi utilizada por Berio em Epifanie ${ }^{l 1}$, para voz feminina e orquestra, máximo de obra 'aberta' - com o intuito justamente de proporcionar uma imagem de certa condição existencial e ontológica do mundo contemporâneo - a obra de James Joyce".

10. Paira uma certo mal entendido sobre a relação entre a noção de Obra Aberta e a Sequenza I, para flauta. É de fato um pouco disparatada a comparação que Umberto Eco faz entre Klavierstück XI, por exemplo, e a Sequenza I. Na primeira, há realmente uma intenção clara de permitir maiores liberdades ao intérprete, deixando a seu critério a escolha da ordem dos fragmentos para a montagem da peça. Já na Sequenza I, a notação proporcional teria sido adotada para permitir uma execução mais cômoda ao intérprete e não para delegar a ele qualquer tipo de escolha. Porém, como aponta Edward Venn (in HALYARD, 2007, p. 171), o próprio Berio teria sido cúmplice desse mal entendido, aceitando de bom grado participar do rol das peças utilizadas por Eco para comentar a noção de abertura em música. Esse mal entendido fica ainda mais explícito quando, em 1992, Berio decide reescrever a Sequenze I em notação convencional, após inúmeras decepções com intérpretes que acabavam conferindo à peça um caráter quase improvisatório, contrariando sua intenção inicial. Acentua ainda mais esse mal entendido o fato de a Sequenza I ter sido originalmente escrita em notação convencional e, somente num segundo momento, ter sido transcrita para notação proporcional. Segundo Paul Roberts (in HALFYARD, 2007, p. 15), assistente pessoal de Berio por quase 13 anos, a estréia da Sequenza I apresentada por Gazzelloni teria sido realizada a partir da partitura original, em notação convencional.

11. O título da peça é inspirado na noção de epifania presente na obra de Joyce, apresentada pela primeira vez no 
escrita um pouco depois da Sequenza I, entre 1959 e 1961. Epifanie é constituída através da interpolação de um ciclo instrumental e de um ciclo vocal. O ciclo instrumental é composto por um conjunto de três Quaderni, que podem ser executados separadamente. Cada um desses Quaderni, por sua vez, é compostos por três fragmentos instrumentais: Quaderni I: A + B + C, Quaderni II: D + E + F, e Quaderni III: G + D + C. Para a montagem de Epifanie, além dos sete fragmentos instrumentais apresentados pelo conjunto dos três Quaderni (A, B, C, D, E, F, G), o intérprete (nesse caso, o regente) tem à sua disposição outros cinco fragmentos (a, b, c, d, e) que compõe o ciclo vocal. Segundo Berio (apud OSMOND-SMITH, 1985b, p. 147), “o ciclo vocal aparece como uma epifania, isto é, como uma espécie de aparição repentina, na textura orquestral mais complexa" ${ }^{\prime 2}$. Cada um dos cinco fragmentos que compõe o ciclo vocal é elaborado a partir de textos de diferentes escritores, em cinco línguas distintas, selecionados por Umberto Eco: a: Marcel Proust, b: Bertolt Brecht, c: Antonio Machado, d: James Joyce, e: Claude Simon. Epifanie utiliza ainda um curto poema de Sanguineti que deve ser lido no início do fragmento instrumental G. A partir desse material, Berio oferece ao intérprete dez possibilidades de combinação dos fragmentos instrumentais e vocais para a montagem da peça:

\begin{tabular}{|ccccccccccccc|}
\hline 1. & A & a & B & c & F & E & d & G & D & e & b & C \\
2. & A & a & B & b & C & c & D & d & E & e & G & F \\
3. & A & a & B & c & b & D & d & e & E & F & G & C \\
4. & c & A & a & B & d & F & b & C & e & E & G & D \\
5. & G & A & a & B & d & F & b & C & e & E & G & D \\
6. & G & A & a & B & e & E & c & F & d & D & b & C \\
7. & a & B & c & A & b & F & e & G & E & D & d & C \\
8. & G & E & c & F & A & a & B & b & e & D & d & C \\
9. & D & b & e & G & a & B & F & c & A & E & d & C \\
10. & G & A & c & F & a & B & D & C & d & e & b & E \\
\hline
\end{tabular}

Fig. 01 - Possibilidades de montagem para Epifanie.

livro Retrato do artista quando jovem. Ver OSMOND-SMITH, 1985b, p. 147.

12. "The vocal cycle appears as an epiphany, that is, as a kind of sudden apparition, in the more complex orchestral texture". 
Tanto a Sequenza I quanto Epifanie evidenciam a diferença entre o pensamento de John Cage, por exemplo, e a idéia de obra aberta, que passava a ganhar força entre os compositores pós-seriais de Darmstadt ${ }^{13}$. No processo de construção das duas peças, Berio não lida com o aleatório em todas as dimensões da obra. Na Sequenza I, a abertura resultante da notação proporcional é balanceada por traços de elaboração serial das alturas. Em Epifanie, a abertura resultante da liberdade dada ao intérprete para a montagem das seções é balanceada pela delimitação precisa de cada um dos materiais que compõe os ciclos instrumental e vocal, além da restrição de possibilidades para os percursos formais (limitados a dez opções). Assim, ao conjugar a composição de estruturas bem determinadas a diferentes estratégias de abertura, essas peças expõem a tensão que é própria à noção de obra aberta.

Obras abertas não são indeterminadas, nem totalmente desvinculadas de estruturas pré-existentes, mas sim suspensas entre muitas estruturas diferentes, porém completamente determinadas. Portanto elas habilitam um compositor, ao menos em princípio, a reconciliar os imperativos aparentemente contraditórios do controle completo, que atingiu sua apoteose com o serialismo integral das primeiras obras de Boulez e Stockhausen, e a liberdade na performance que foi a marca das obras aleatórias de John Cage (MURPHY, 1999) $)^{14}$.

Assim, Umberto Eco reforça a importância de compreender a expressão "obra aberta" como a conciliação de dois termos aparentemente conflitantes: "obra" e "abertura". Eco comenta que o dicionário, por exemplo, é integralmente "aberto", pois fornece uma enorme quantidade de palavras com as quais é possível compor uma infinidade de poemas. Porém, o dicionário não é uma obra em si. O exemplo de Eco é quase elementar, mas evidencia um valor central da poética de abertura: para ser "obra", ainda que aberta, é necessário que se "mantenha uma fisionomia de organismo e manifeste, qualquer que seja a forma pela qual for entendida ou prolongada, a marca pessoal em virtude da qual consiste, vale e comunica" (ECO, 1976, p. 63).

13. Apesar da noção de obra aberta ser de certa maneira atravessada por idéias como aleatoriedade e indeterminação, o compositor não abre mão de exercer controle sobre os materiais pré-composicionais. Aqui há uma distinção entre o trabalho de John Cage, por exemplo, e o dos compositores de Darmstadt. Um texto que ilustra bastante bem esse debate é Alea, de Pierre Boulez, publicado pela primeira vez em La Nouvelle Revue Française, em 1957. Uma tradução para o português pode ser encontrada em: BOULEZ, Pierre. Apontamentos de Aprendiz. São Paulo, Perspectiva, 1995.

14. "Open works are not indeterminate, not totally without pre-existing structure, but rather suspended between many different but fully determinate structures. Thus they enable a composer, in principle at least, to reconcile the apparently contradictory imperatives of complete control, which reached its apotheosis in the total serialism of the earlier Boulez and Stockhausen, and the freedom in performance that was the hallmark of Cage's aleatory works". 
No texto $O$ Alter Duft, de Berio, é possível encontrar fortes ressonâncias da reflexão realizada por Eco em Obra Aberta. O Alter Duft é na verdade a transcrição de uma das conferências proferidas por Berio na renomada série The Charles Eliot Norton Lectures, na Universidade de Harvard, durante o ano letivo de 1993-94. O conjunto de seis conferências, que inclui $O$ Alter Duft, foi publicado em 2006 sob o título Remembering the future. Nessa conferência, apresentada cerca de quarenta anos após o auge da idéia de obra aberta tanto na literatura quanto na música, Berio fala da importância de tal conceito para a formação de seu pensamento composicional. Iniciando com uma brincadeira a respeito do título da conferência ${ }^{15}$, Berio (2006, p. 79) diz: "O antigo perfume que eu tentarei evocar é aquele da 'obra aberta', uma experiência que marcou profundamente os músicos da minha geração e que continua, ocasionalmente, a provocar antigas questões" ${ }^{\text {16 }}$. Em seguida, o texto passa à exposição da noção de obra aberta onde Berio retoma a relação conflituosa entre fechamento e abertura, exposta por Eco como uma tensão própria ao conceito de obra aberta:

Uma concepção de forma musical que tende à abertura implica no desejo se não exatamente na possibilidade - de seguir e desenvolver caminhos formais que sejam alternativos, inesperados, não-homogêneos, e o mais importante, não lineares. Mas alternativos e inesperados com relação ao quê? Obviamente, principalmente com relação a termos estabelecidos pelo compositor na concepção concreta do trabalho. Em qualquer obra que pode ser definida como aberta, há um óbvio paradoxo (BERIO, 2006, p. 80) ${ }^{17}$.

Berio enfatiza a importância da noção de obra aberta nos anos 50 e 60 não somente por possibilitar um novo tipo de estruturação da forma, mas principalmente pelo debate que ela pôde gerar dentro da própria noção de forma. Porém, tendo tomado a devida distância dos problemas estéticos próprios àquela época, Berio passa a se posicionar em seu texto de maneira crítica, comentando certas aporias que teriam surgido diante das propostas de abertura durante as décadas de 50 e 60. São conhecidos os motivos que fizeram com que Berio transcrevesse a Sequenza I para notação rítmica convencional, em 1992. Já em 1966,

15. O título $O$ Alter Duft remete à primeira linha do poema utilizado por Schoenberg na última das peças do Pierrot Lunaire: "Ó antiga fragrância de outrora" / [ "O alter Duft aus Märchenzeit"].

16. "The old perfume I will be trying to evoke is that of the "open work", an experience that profoundly marked the musician of my generation, and which continues, occasionally, to stir up old questions".

17. "A conception of musical form that tends towards openness implies the desire - if not exactly the possibility - to follow and develop formal pathways which are alternative, unexpected, non-homogeneous, and most important, not linear. But alternative and unexpected with respect to what? Obviously, mainly with respect to terms established by the composer in the actual conception of the work. In any work that can be defined as open, there is an obvious paradox". 
em carta enviada Aurèle Nicolet ${ }^{18}$, Berio manifestaria seu desagrado com a imprecisão de todas as interpretações que havia escutado até então. Em entrevista a Theo Muller (BERIO, 1997, p. 19), concedida em 1995, Berio manteria sua reclamação, dizendo que com a notação proporcional os intérpretes acabavam por se permitir liberdades excessivas. Os problemas resultantes dessas propostas de abertura iriam ainda além da dificuldade de interpretação da partitura por parte dos instrumentistas. A própria estratégia de oferecer ao intérprete a possibilidade de montagem formal da peça, como em Epifanie, seria esvaziada de seu potencial de abertura no momento de sua execução. Para Berio, o problema desse tipo de proposta estaria em constatar que a multiplicidade formal seria de certa forma "aristocrática", na medida em que poderia ser percebida somente pelo compositor, pelo intérprete e pelo ouvinte que tivesse a oportunidade de escutar a peça mais de uma vez. Um segundo problema seria a constatação de que, levada a extremos, a idéia de obra aberta conduziria a uma perigosa "renúncia", isto é, na medida em que um maior volume de parâmetros se abre à intervenção do intérprete, a própria partitura se esvazia tendendo, metaforicamente, ao silêncio. Segundo Berio (2006, p. 91), “o texto torna-se assim uma renúncia, torna-se pobre, até mesmo espiritualizado - torna-se, em outras palavras, a paródia melancólica de uma viagem em direção ao silêncio""19.

Para Berio, a noção de obra aberta volta a ganhar força se compreendida sob nova perspectiva. Na Sequenza I e em Epifanie, vimos duas maneiras bastante explícitas de execução do projeto de obra aberta, empregadas em diversas peças produzidas naquele período. Porém, num contexto renovado, Berio resgata a noção de obra aberta para compreender a forma musical em peças como A Sagração da Primavera, por exemplo. Um comentário mais detalhado acerca da Sagração é realizado em Poetics of Analysis, a transcrição da sexta e última conferência da série The Charles Eliot Norton Lectures. Nesse texto, Berio diz que a Sagração lida, dialeticamente, com uma extrema concentração e uma acentuada diversificação, ou seja, ela conjuga forças opostas em cada uma de suas dimensões estruturais. Para Berio (2006 p. 126), a Sagração seria uma peça onde "uma tendência à autonomia de caráter e de relações estruturais coexiste com um processo independente, dedutivo e generativo" 20 . Dessa maneira, Berio atualiza a noção de obra aberta em novo

18. Um longo trecho dessa carta está transcrito em FOLIO, Cynthia; BRINKMAN, Alexander R. Rhythm and timing in the two versions of Berio's Sequenza I for flute solo: psychological and musical differences in performance, in HALFYARD, 2007.

19. "The text thus becomes a renunciation, it becomes impoverished, even spiritualized - it becomes, in other words, the wistful parody of a voyage toward silence".

20. "A tendency toward autonomy of character and structural relations, on the one hand, coexist with 
contexto. Isso significa dizer que a noção de obra aberta também pode estar presente numa peça que se utilize de uma escrita fechada, isto é, que não permita maiores liberdades ao intérprete do que aquelas já pressupostas no repertório tradicional. Nesse caso, entramos num campo onde a noção de obra aberta passa a um nível mais profundo da criação artística, tornando-se parte integrante da concepção e da poética de uma obra (ou de um compositor) e não somente expondo certos aspectos de superfície notoriamente reconhecidos como abertos. É dentro dessa perspectiva que abordaremos a Sonata nos capítulos seguintes. Da mesma maneira que a Sagração, a Sonata se apresenta como um espaço de embate e conciliação entre a autonomia de relações estruturais pré-elaboradas e a proliferação de relações processuais locais. Nossa intenção não é a de rotular a Sonata, que foi composta em 2001, como uma manifestação anacrônica do projeto de obra aberta, mas sim identificar de que maneira algo dessa antiga fragrância teria marcado a poética de Berio durante todo seu percurso criativo, contribuindo para o surgimento de estratégias composicionais como reescritura, gesto e processo.

independent, deductive, and generative process, on the other". 
capítulo II - reescritura 


\section{IIa. sobre a noção de reescritura} em Berio

Em sua segunda conferência apresentada na série The Charles Eliot Norton Lectures durante o ano letivo de 1993-9421, intitulada Translating Music, Berio comenta o trabalho de transcrição musical sob uma perspectiva histórica, fazendo também um paralelo com a prática de tradução de textos, própria à literatura. Tanto o processo de tradução de um texto quanto o de transcrição de uma música implicam em interpretação e resvalam de certa maneira no campo da criação. Segundo Berio, a partir do século XX, alguns trabalhos passam a oferecer maior resistência tanto à tradução literária quanto à transição musical. Esse seria o caso de Finnegans Wake, de James Joyce, por exemplo, onde "o simbolismo, a sintaxe, a fonética, o imaginário icônico, e o conteúdo gestual criam uma série de curtos-circuitos semânticos, uma polifonia de associações que não deixam margem para quaisquer expressões ou enunciações alternativas" (BERIO, 2006, p. 37)22. Para Berio, traduzir Finnegans Wake, Le Livre de Mallarmé, ou a poesia de e.e cummings, seria o mesmo

21. Publicada em BERIO, Luciano. Remembering the future. Cambridge, MA, Harvard University Press, 2006. 22. "The symbolism, the syntax, the phonetics, iconic imagery, and gestural content create a series of semantic short circuits, a polyphony of associations that leave no leeway whatsoever for alternative expressions or enunciations". 
que transcrever obras como Jeux de Debussy, Music for strings, Percussion and Celesta de Bartók, Le Marteau sans Maître de Boulez, Double Concerto de Carter, Gruppen de Stockhausen, ou ainda grande parte dos seus próprios trabalhos. Em todos esses casos as obras resistem a um processo de transcrição: "elas podem somente ser interpretadas,

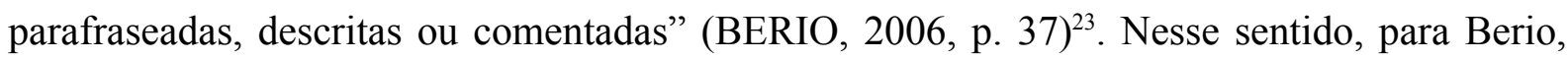
qualquer tentativa de transcrição da música dos séculos XX e XXI acabaria por invadir completamente o campo da criação musical. Compreendida nesses termos, como um processo de recriação, a transcrição passaria a operar como reescritura: "A transcrição em Berio não é variação, mas reescritura: ela compreende a integração de um trabalho realizado a um contexto sonoro que o transforma" (STOIANOVA, 1985, p. 425) ${ }^{24}$.

Em nossa extensa leitura sobre Luciano Berio, não nos deparamos com a expressão reescritura em nenhum dos textos de sua autoria. Berio sempre se referiu ao processo de reescritura simplesmente como transcrição ou comentário ${ }^{25}$. Em nosso trabalho, seguiremos a indicação de Stoianova e adotaremos a idéia de reescritura para tratar dos diferentes processos de transcrição utilizados por Berio. Assim, entenderemos por reescritura um processo de transcrição que passa pelo crivo analítico ${ }^{26}$ e criativo. Segundo Silvio Ferraz:

A reescritura implica em uma análise do material sonoro e musical de
partida, seja uma análise no sentido tradicional para identificar elementos
melódicos, harmônicos, técnico instrumental, seja em um sentido mais
estendido como nas análises espectrais e análises de procedimentos técnicos
de produção da obra que serviu de fundamento (FERRAZ, 2007, p. 9) (27. $^{27}$

Ao tratarmos da noção de reescritura, nos deparamos novamente com certas características da poética da obra aberta, mais especificamente com a idéia de work in progress. A expressão work in progress aparece na obra de Joyce como título dado à reunião de fragmentos que comporiam o livro Finnegans Wakes, no qual Joyce trabalhou por 16 anos antes da sua publicação final, em 1939. De certa forma, o processo de reescritura está ligado à

23. "They may only be interpreted, paraphrases, described, or comented upon".

24. "La transcription chez Berio n'est pas variation, mais ré-écriture: elle comprend l'intégration d'une ouvre achevée à un contexte sonore qui la transforme".

25. Em sua monografia Berio (1991), o pesquisador Osmond-Smith dedica um capítulo inteiro ao estudo da técnica do comentário [commentary technique] em Berio.

26. São diversos os comentários de Berio afirmando que seus Chemins e o terceiro movimento de sua Sinfonia, seriam as melhores análises que ele poderia ter feito das Sequenze e da música de Mahler, respectivamente. (ver BERIO, 1988 p. 95).

27. Para um maior detalhamento da idéia de reescritura, ver FERRAZ, Silvio. A fórmula da reescritura. In: Anais do III Seminário Música Ciência e Tecnologia - Sonologia (2008), pp. 41-51. 
noção joyceana de work in progress na medida em que o autor revisita um texto anterior para atualizá-lo em um novo contexto, considerando diferentes desdobramentos de um determinado material e apresentando faces variadas de uma mesma idéia. Porém, as noções de reescritura e work in progress não são coincidentes. Em geral, costuma-se nomear de work in progress certas peças que se encontram inacabadas e que passam por constantes processos de reelaboração. Assim, os trabalhos alinhados com a idéia de work in progress em geral são concretamente abertos, pois ainda não foram de fato encerrados. Já na reescritura a noção de abertura está no fato de que uma obra, ao se reportar a um trabalho anterior, provoca uma abertura em si mesma e também no trabalho de origem, na medida em que atualiza ambos em um novo contexto. Um exemplo bastante explícito de tal situação seria o terceiro movimento da Sinfonia de Berio que, ao fazer uso do Scherzo da Segunda Sinfonia (Ressurreição) de Mahler, coloca as duas peças numa perspectiva de abertura: a Sinfonia de Mahler modula a Sinfonia de Berio, ao passo que a Sinfonia de Berio modula a de Mahler. Quando uma situação como essa ocorre entre peças de um mesmo compositor, a aproximação entre as noções de work in progress e reescritura fica ainda mais clara, tornando-se difícil dissociá-las. Segundo Penha (2010, p. 9), "reescritura e work in progress não são excludentes, mas também não são uma e só e mesma coisa, podendo no máximo ser complementares".

Os Chemins, compostos a partir de algumas das Sequenze, constituem o melhor exemplo de reescritura em Berio, e talvez em toda a literatura musical do século XX. Eles seriam um trabalho de comentário e amplificação de algumas potências não desenvolvidas nas Sequenze. A respeito dos Chemins, em nota de programa de sua própria autoria, Berio diz:

Eles são uma série de comentários específicos que incluem, quase intactos, o objeto e o assunto do comentário. Os Chemins não são um deslocamento de um objet trouvé num contexto diferente ou uma "roupagem" orquestral de uma peça solo (a Sequenza original), mas sim um comentário organicamente ligado a ela e gerado por ela. O conjunto instrumental traz para a superfície e desenvolve processos musicais que estão escondidos e comprimidos na parte solista, amplificando todos os aspectos, inclusive os temporais: em alguns momentos os papéis se invertem de modo que a parte solista parece ter sido gerada pelo próprio comentário (CENTRO STUDI) ${ }^{28}$.

28. "They are a series of specific commentaries which include, almost intact, the object and subject of the commentary. The Chemins are not the displacement of an objet trouvé into a different context or the orchestral "dressing up" of a solo piece (the original Sequenza), but rather a commentary organically tied to it and generated by it. The instrumental ensemble brings to the surface and develops musical processes that are hidden and compressed in the solo part, amplifying every aspect, including the temporal one: at times the roles are inverted so that the solo part appears to be generated by its own commentary". 
A série de Chemins inclui os seguintes trabalhos: Chemins I (1965), para harpa e orquestra, sobre Sequenza II (1963), para harpa; Chemins II (1967), para viola e 9 instrumentos, sobre Sequenza VI (1967), para viola; Chemins IIb (1970), para orquestra, sobre Sequenza VI (1967), para viola; Chemins IIc (1972), para clarinete baixo e orquestra, sobre Sequenza VI (1967), para viola; Chemins III (1968), para viola e orquestra, sobre Chemins II (1967), para viola e 9 instrumentos; Chemins IV (1975), para oboé e 11 instrumentos de cordas, sobre Sequenza VII (1969), para oboé; e Chemins V (1992), para violão e orquestra de câmara, sobre Sequenza XI (1988), para violão. Há três outras peças que podem ser consideradas parte da série de Chemins, ainda que apresentem outros títulos: Corale (1981), para violino, duas trompas e orquestra, sobre a Sequenza VIII (1976), para violino; Kol od (1996), para trompete e grupo instrumental, sobre a Sequenza X (1984), para trompete; e Recit (1996), para saxofone alto e orquestra, sobre a Sequenza IXb, para saxofone alto (1980).

Entre os Chemins, o caso que mais emblemático do processo de reescritura é o conjunto de peças formado pela Sequenza VI (1967) para viola, Chemins II (1967), IIb (1970), IIc (1972) e III (1968) ${ }^{29}$. Nos Chemins II e III, a viola é mantida como solista e executa literalmente a Sequenza VI. Enquanto no Chemins II o material apresentado pela viola é comentado por um conjunto formado por outros 9 instrumentos, no Chemins III, o mesmo processo é amplificado para uma formação orquestral, modulando a Sequenza VI em um novo contexto instrumental. Nos dois casos há algumas modificações na estrutura original da Sequenza VI, ainda que de maneira sutil. No Chemins II alguns gestos curtos são inseridos pelo conjunto instrumental como breves interpolações, em momentos onde a viola permanece em silêncio, enfatizando o aspecto concertante da peça. Já no Chemins III, esse processo é expandido e acentuado durante uma seção mais longa de interpolações entre o material do solista e da orquestra. Um trabalho de reescritura mais livre da Sequenza VI seria realizado dois ano depois, em Chemins IIb, onde a parte de viola solo é diluída dentro da orquestra, abandonando o caráter concertante presente em Chemins II e III. A série conta ainda com Chemins IIc que pode ser considerado uma variação do Chemins IIb, com o acréscimo de um clarinete baixo solo, incluído em 1972. Na nota de programa da estréia de Chemins IIc, ao se referir à relação entre este e os Chemins $I I$ e $I I b$, Berio diz:

29. Para uma análise comparativa mais detalhada entre a Sequenza VI e seus Chemins, ver OSMOND-SMITH, 1991, pp. 42-53, além do artigo Proliferation and Limitations: Berio's Reworking of the Sequenzas, de Edward Venn em HALFYARD, 2007, pp. 171-188. 
Esses três Chemins estão relacionados entre si assim como as camadas de uma cebola: distintas, separadas, ainda que intimamente moldadas entre si; cada nova camada cria uma outra, porém relacionada, superfície, e cada camada anterior assume uma nova função assim que é coberta (BERIO, 1972 apud ROBERTS in HALFYARD, 2007, p. 125) ${ }^{30}$.

Como aponta Edward Venn (in HALFYARD, 2007, p. 187), apesar da ordem cronológica de composição da Sequenza VI e de seus respectivos Chemins, não se pode considerar que qualquer uma delas detenha alguma primazia ontológica sobre as demais. Estando todas à disposição dos ouvintes, estes podem fazer seus próprios percursos e conexões. Significaria dizer que, se ignorássemos a data de composição das peças, a Sequenza VI poderia ser compreendida como uma reescritura de Chemins IIb. Nesse sentido, a convergência entre as noções de reescritura e de work in progress torna-se ainda mais evidente. Ainda no terreno joyceano, Osmond-Smith aproxima o processo de construção desse conjunto de peças - Sequenza VI e Chemins II, IIb e III - à idéia de estratificação em Joyce, chamando atenção para o efeito que o conjunto provoca sobre o ouvinte no momento em que ele se depara com diferentes obras que expõe, de maneiras distintas, um mesmo material musical:

Se o processo de estratificação de Finnegans Wake sugere, de maneira monstruosa e hilária, uma auto-perpetuação, então as diversas proliferações a partir da Sequenza VI para viola enfatizam a natureza temporária das soluções criativas e demandam, por parte dos ouvintes/leitores da partitura, não só uma fruição passiva, mas uma crítica ativa (OSMOND-SMITH, 1983 , p. 88$)^{31}$.

O trabalho de reescritura é explorado de diferentes maneiras por Berio. Grosso modo, poderíamos dividir as peças onde Berio se utiliza de textos anteriores em três grupos, considerando os materiais de origem: um primeiro grupo seria formado por peças que dialogam com músicas de culturas tradicionais; um segundo grupo seria formado por composições que retomam textos de outros autores; e finalmente, um terceiro grupo seria formado por peças onde Berio revisita textos de sua própria autoria. Os exemplos em cada um

30. "These three Chemins are related to each other something like the layers of an onion: distinct, separate, yet intimately contoured on each other; each new layer creates a new, though related surface, and each older layer assumes a new function as soon as it is covered".

31. "Si les processus de stratification de Finnegans Wake suggèrent, de manière monstrueuse et hilarante, une auto-perpétuation, alors les diverses proliférations à partir de Sequenza VI pour alto insistent sur la nature temporaire de solutions créatives et demandent, de la part des auditeur/lectures de la partition, non pas une consommation passive, mais une critique active". 
desses grupos são numerosos. No primeiro grupo estariam peças como Folk Songs (1964, rev. 1973), Coro (1974-76), Voci (1984) e Naturale (1985), por exemplo, que dialogam com diferentes universos folclóricos. No segundo grupo estariam peças como Sinfonia (1968-69) que dialoga com o terceiro movimento (secherzo) da Segunda Sinfonia (Ressurreição) de Mahler - e Rendering (1990) - escrita a partir dos esboços da Décima Sinfonia de Schubert. No terceiro grupo, além da série de Chemins, estariam peças como "Points on a curve to find..." (1974) - onde Berio escreveu primeiro toda a parte de piano para, num segundo momento, escrever os demais instrumentos, expandindo e comentando as idéias apresentadas pelo piano ${ }^{32}$ - e o Concerto II (1988-89), que parte de materiais de "Points on a curve to find...".

Dentro desse último grupo encontra-se a Sonata per pianoforte (2001), nosso objeto de pesquisa, que foi escrita a partir de Interlinea (2000), também para piano solo. Portanto, a Sonata, ainda que escrita no início do século XXI, apresenta uma estratégia composiconal recorrente na obra de Berio desde os anos 60 e que, como vimos, também é atravessada por uma poética de abertura. Em nota de programa elaborada para alguns dos Chemins, Berio diz:

Por que esta insistência em elaborar e transformar de novo o mesmo material? É, talvez, um tributo à crença de que uma coisa feita nunca está terminada. Mesmo a obra 'completa' é o ritual e o comentário de algo que a precedeu, de algo que a seguirá, como uma pergunta que não provoca uma resposta mas um comentário, e uma outra pergunta...(CENTRO STUDI) ${ }^{33}$.

32. Procedimento similar ao utilizado entre as Sequenze e os Chemins, a não ser pelo fato de que a parte de piano solo de "Points on a curve to find..." não ter sido publicada separadamente.

33. "Why this insistence on elaborating and transforming again the same material? It is, maybe, a tribute to the belief that a thing done is never finished. Even the "completed" work is the ritual and the commentary of something which preceded it, of something which will follow it, as a question that does not provoke an answer but a commentary, and another question...". 


\title{
IIb. reescritura na Sonata $^{34}$
}

\begin{abstract}
Assim como muitas outra peças de Berio, a Sonata tem suas raízes em um trabalho anterior. Em 26 de março de 2000, no Queen Elisabeth Hall (Londres), foi realizado um concerto em comemoração ao $75^{\circ}$ aniversário de Pierre Boulez. Inspirado em Notations (1945) - ciclo de 12 peças para piano de Boulez -, o programa do concerto consistia na estréia de doze peças também para piano solo, encomendadas e escritas especialmente para a ocasião, e interpretadas pelo pianista inglês Rolf Hind. Dentre as peças do concerto estava Interlinea per pianoforte, de Berio, que serviria como matriz para a composição da Sonata no ano seguinte.

Interlinea está presente na Sonata de maneira integral. Os gráficos apresentados a seguir indicam de forma sintética as correlações entre os trechos de Interlinea e da Sonata. O Quadro Comparativo A (Fig. 2) segue a ordenação dos compassos da Sonata e apresenta sua correlação com Interlinea. O Quadro Comparativo B (Fig. 3) é construído de maneira inversa, isto é, segue a ordenação dos compassos de Interlinea e apresenta sua correlação com a
\end{abstract}

34. A partir desse tópico, por se tratar de um trabalho essencialmente de análise musical, apresentaremos diversos exemplos com o intuito de ilustrar o comentário realizado no corpo do texto. Na maior parte dos casos, é fundamental que o leitor se reporte à partitura completa tanto de Interlinea quanto da Sonata (que se encotram em anexo) para que possa confrontar os exemplo reduzidos com os trechos originais. 
Sonata. Para a leitura dos dois Quadros, é essencial considerar a seguinte legenda:

\section{$\underline{\text { Legenda }}$}

- Os números inseridos após a barra diagonal indicam o tempo do compasso. Exemplo: 065/4 - 071/3 se refere ao trecho compreendido entre o início do quarto tempo do compasso 65 até o fim do terceiro tempo do compasso 71;

- Nos casos onde não há indicações referentes aos tempos de compasso como explicado no item anterior, os compassos deverão ser considerados de maneira integral. Exemplo: 001 - 007 se refere ao trecho compreendido entre o início do primeiro tempo do compasso 1 e o fim do compasso 7;

- A letra "L" inserida após a barra indica que o trecho inclui o levare, isto é, figuras que foram apresentadas no compasso anterior geralmente em forma de apojaturas. Exemplo: 013/L - 031/1 se refere ao trecho compreendido entre o levare para o compasso 13 e o fim do primeiro tempo do compasso 31;

- O compasso 48 de Interlinea é citado duas vezes na Sonata e, por isso, é acompanhado de um asterisco (*). Esta ocorrência é única;

- Os trechos coloridos em laranja indicam as correlações diretas entre as duas peças;

- Os trechos coloridos em verde e destacados em negrito não apresentam correlação direta com trechos da outra obra. 
Quadro Comparativo A - Seguindo a ordenação dos compassos da Sonata

\begin{tabular}{|c|c|c|c|c|c|c|c|}
\hline \multicolumn{8}{|c|}{ Quadro Comparativo A - Seguindo a ordenação dos compassos da Sonata } \\
\hline Sonata: & $001-041 / 2$ & $041 / 3-045 / 3$ & $045 / 4-047 / 4$ & $047 / 5-050$ & $051-065 / 3$ & $|065 / 4-071 / 3|$ & $071 / 4-072 / 2$ \\
\hline Interlinea: & & $031 / 2-034 / 1$ & & $034 / 1-035$ & & $001-007$ & \\
\hline Sonata: & $072 / 3-075$ & $076-078$ & 079/L - 100 & $\mid 101 / 4-111 / 2$ & $111 / 3-128$ & $129-133$ & $134-135 / 2$ \\
\hline Interlinea: & $008-012$ & & 013/L-031/1 & $036 / 2-047 / 3$ & & $048^{*}-052$ & \\
\hline Sonata: & $135 / 3-136 / 3$ & $136 / 4-187 / 3$ & $187 / 4-188 / 2$ & $188 / 3-189 / 1$ & $189 / 2-190 / 1$ & $190 / 2-191 / 1$ & $191 / 2-191 / 4$ \\
\hline Interlinea: & $47 / 4-48^{*}$ & & $062 / 3-063$ & 068/L-069/1 & & $069 / 2-070$ & \\
\hline Sonata: & 192/L- 194 & 195 & 196 & $197-302 / 6$ & $302 / 7-305 / 1$ & $305 / 2-305 / 5$ & $306-311 / 1$ \\
\hline Interlinea: & $064 / L-067$ & $061-062 / 2$ & $071-072 / 1$ & & $072 / 2-073$ & & $053-060$ \\
\hline Sonata: & $311 / 2-316 / 3$ & $316 / 4-337$ & & & & & \\
\hline Interlinea: & $074-075$ & & & & & & \\
\hline
\end{tabular}

Fig. 02 - Quadro Comparativo A: correlações diretas entre a Sonata e Interlinea.

\begin{tabular}{|c|c|c|c|c|c|c|c|}
\hline \multicolumn{8}{|c|}{ Quadro Comparativo B - Seguindo a ordenação dos compassos de Interlinea } \\
\hline Interlinea: & $001-007$ & $008-012$ & $013 / L-031 / 1$ & $031 / 2-034 / 1$ & $034 / 1-036 / 1$ & $036 / 2-047 / 3$ & $47 / 4-48^{*}$ \\
\hline Sonata: & $065 / 4-71 / 3$ & $072 / 3-075$ & $079 / L-100$ & $041 / 3-045 / 3$ & $047 / 5-050$ & $101 / 4-111 / 2$ & $135 / 3-136 / 3$ \\
\hline Interlinea: & $048^{*}-052$ & 53 & $054-060$ & $061-062 / 2$ & $062 / 3-063$ & $064 / L-067$ & 068/L-069/1 \\
\hline Sonata: & $129-133$ & & $306-311 / 1$ & 195 & $187 / 4-188 / 2$ & 192/L - 194 & $188 / 3-189 / 1$ \\
\hline Interlinea: & $069 / 2-070$ & $071-072 / 1$ & $072 / 2-073$ & $074-075$ & & & \\
\hline Sonata: & $190 / 2-191 / 1$ & 196 & $302 / 7-305 / 1$ & $311 / 2-316 / 3$ & $316 / 4-337$ & & \\
\hline
\end{tabular}

Fig. 03 - Quadro Comparativo B: correlações diretas entre Sonata e Interlinea. 
A leitura dos Quadros Comparativos A e B (Fig. 2 e Fig. 3) permite verificarmos a distribuição do material de Interlinea dentro na Sonata. ${ }^{35}$ Porém, o modo como cada trecho de Interlinea é aproveitado na Sonata é variável. Demonstraremos a seguir quatro maneiras diferentes de utilização desse material através dos procedimentos de citação, ampliação, derivação e proliferação.

\section{a) $\underline{\text { Citação }}$}

Chamaremos de citação a utilização quase literal de uma peça dentro de outra, permitindo certa flexibilização com relação à notação e a pequenas variações rítmicas e harmônicas. Esse procedimento pode ser verificado no trecho 090 - 100 da Sonata, por exemplo, quando Berio faz uma citação direta do trecho 020 - 031/1 de Interlinea. Comparando os dois trechos em questão, percebe-se que de fato há alterações muito sutis entre eles. Seguindo os compassos da Sonata é possível observar: o acréscimo de uma nota $\mathrm{A} \sharp 5$ no primeiro tempo de c.90; o acréscimo de uma segunda maior ( $\mathrm{E} q-\mathrm{F} \sharp)$ no quarto tempo de c.91; a alteração de um $\mathrm{E}$ b para um $\mathrm{E}$ Ł no quarto tempo de c.94; e o acréscimo de uma nota E b no segundo tempo de c.96. Nota-se também que em c. 100 o F $¥ 5$ que aparecia no trecho equivalente de Interlinea é suprimido e o grupo de fusas sobre a nota $\mathrm{E}$ q é ampliado de um para quatro tempos. Apesar dessas alterações, o movimento global do trecho - seqüência dos gestos, textura, direção, contorno etc - é preservado.

Um outro exemplo desse procedimento pode ser observado no trecho $072-075$ da Sonata, que corresponde ao trecho 008 - 012 de Interlinea, e que apresenta um número maior de variações com relação ao original. Além da diferença de andamentos (54 bpm em Interlinea e $81 \mathrm{bpm}$ na Sonata), os dois trechos aparecem em contextos muito diferentes dentro de cada um das peças. Em Interlinea, esse trecho encontra-se logo no início da peça enquanto na Sonata o trecho reescrito aparece já por volta dos sete minutos de música, após Berio ter completado a apresentação dos gestos principais utilizados na peça. A figura a seguir mostra o trecho original de Interlinea e a maneira como esse mesmo trecho é apresentado na Sonata. Nessa figura, os eventos foram alinhados verticalmente para evidenciar as variações

35. O único trecho que não apresenta correlação direta com a Sonata é o compasso 53 de Interlinea. Porém, apesar de não estar copiado ipsis litteris dentro da Sonata, o material do compasso 53 é recorrente e comum às duas obras. 
rítmicas e métricas entre as duas peças. No trecho referente à Sonata, estão marcadas em azul todas as alterações e acréscimos de notas, além das modificações no uso dos pedais. Também estão marcadas em azul as diferenças com relação às indicações de intensidade, parâmetro este que ganha um detalhamento e uma variabilidade muito maior na Sonata
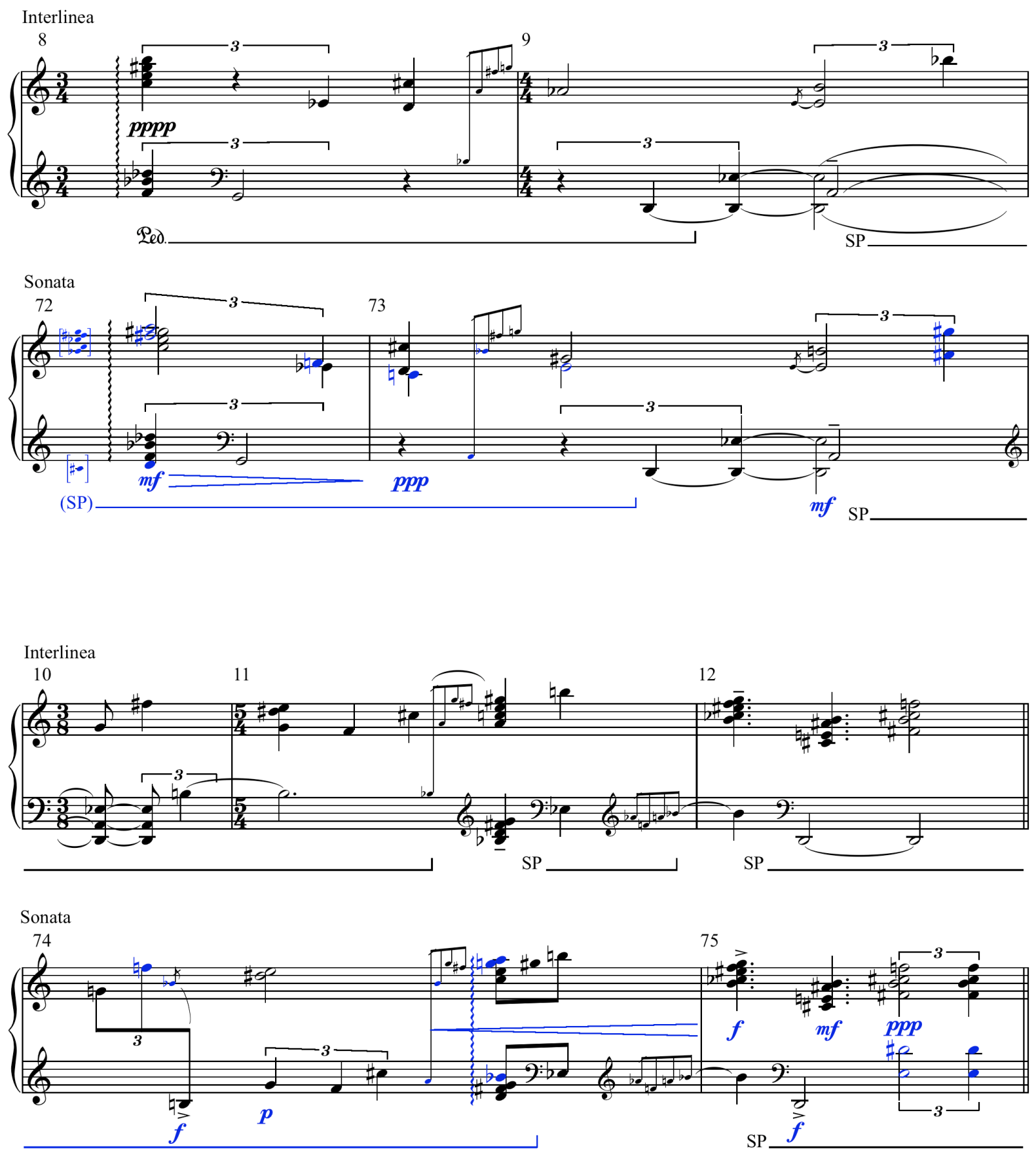

Fig. 04 - Trecho original de Interlinea (c.8 a c.12)

e citação do mesmo trecho dentro da Sonata (c.72 a c.75). 
O exemplo anterior mostra que, apesar de se tratar claramente de um trecho citado de Interlinea, este sofre algumas transformações significativas, principalmente no que se refere ao seu aspecto harmônico. No processo de reescritura do trecho dentro da Sonata, Berio faz alguns ajustes, inserindo algumas notas que não estavam previstas em Interlinea. No caso, há explicitamente uma ênfase no uso das segundas maiores, conforme mostra a análise apresentada na figura a seguir (Fig. 05). Assim, o trecho citado de Interlinea é submetido a um novo contexto harmônico, próprio à Sonata, caracterizado por uma sonoridade harmônica mais densa que privilegia, além das terça menores (características de Interlinea), os intervalos de segunda maior ${ }^{36}$.

O exemplo a seguir coloca foco somente sobre as alterações harmônicas marcadas em azul na Fig. 04. Nesse novo exemplo a comparação do primeiro e do último bloco harmônico mostra com clareza a substituição dos intervalos de terça menor (3) de Interlinea pelos intervalos de segunda maior (2) na Sonata. Nos demais casos (circulados em azul), também é possível verificar o acréscimo de notas não existentes em Interlinea, compondo prioritariamente intervalos de segunda e terça maior (2 e 4) na Sonata:



Fig. 05 - Comparação do material harmônico de um trecho original de Interlinea com seu correspondente reescrito na Sonata através do processo de citação.

36. Os modelos harmônicos presentes na Sonata serão comentados no Capítulo IV. 
b) Expansão

Esse é o recurso mais utilizado na elaboração da Sonata a partir de Interlinea. No processo de expansão Berio fragmenta certos trechos de Interlinea e os amplia temporalmente dentro da Sonata. O trecho 079 - 089 da Sonata, que corresponde ao trecho 013/L - 019 (vide Quadros Comparativos A e B, Fig. 2 e Fig. 3) de Interlinea, constitui um bom exemplo desse procedimento. As duas figuras a seguir mostram o trecho original de Interlinea e seu correspondente na Sonata, respectivamente. Na segunda figura (Fig. 07) estão marcados em azul os elementos coincidentes com a primeira figura (Fig. 06). As marcações em verde indicam pequenas variações rítmicas, notas que tiveram seu registro alterado ou que foram substituídas. Finalmente, as marcações em laranja indicam as expansões realizadas.
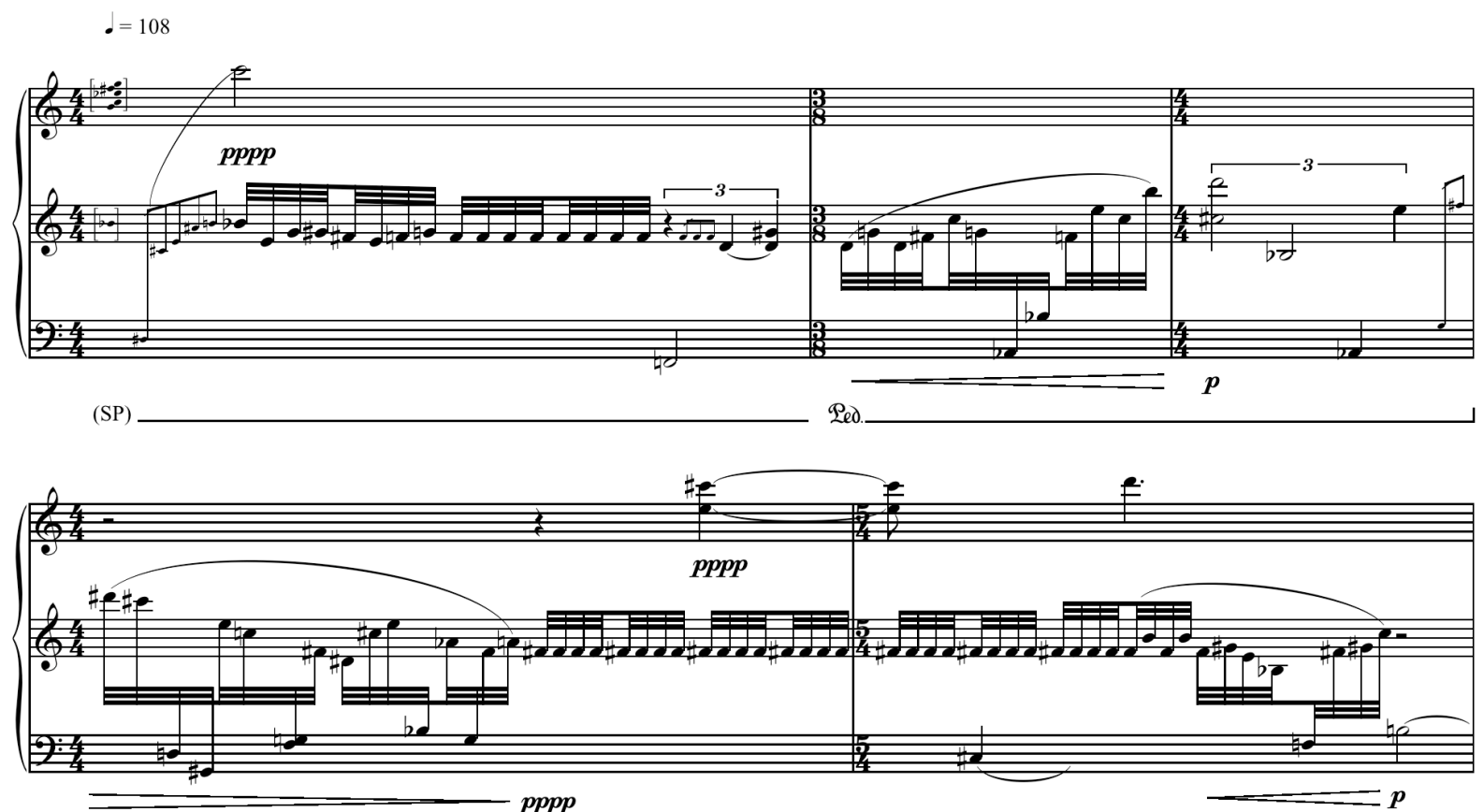

2ed.



Fig. 06 - Trecho original de Interlinea, c.13 a c.19. 


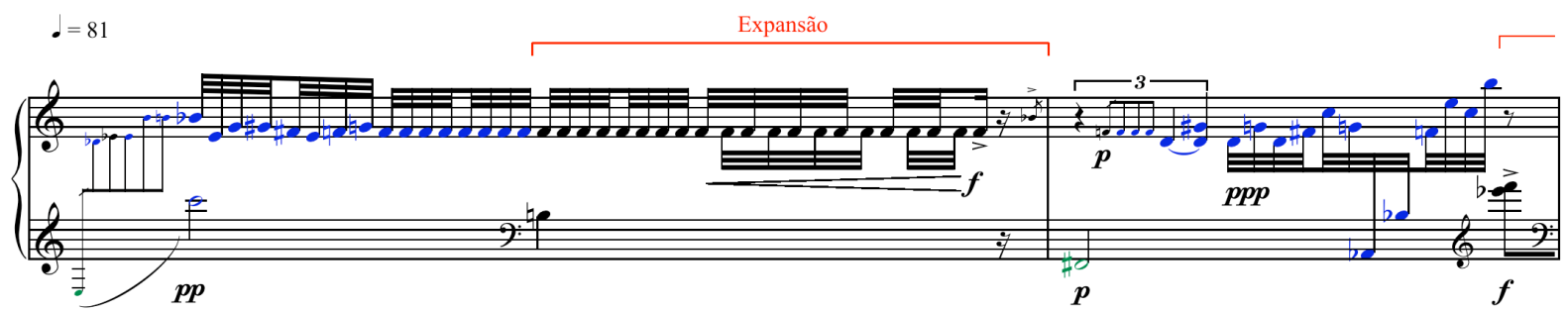

Expansão

Expansão
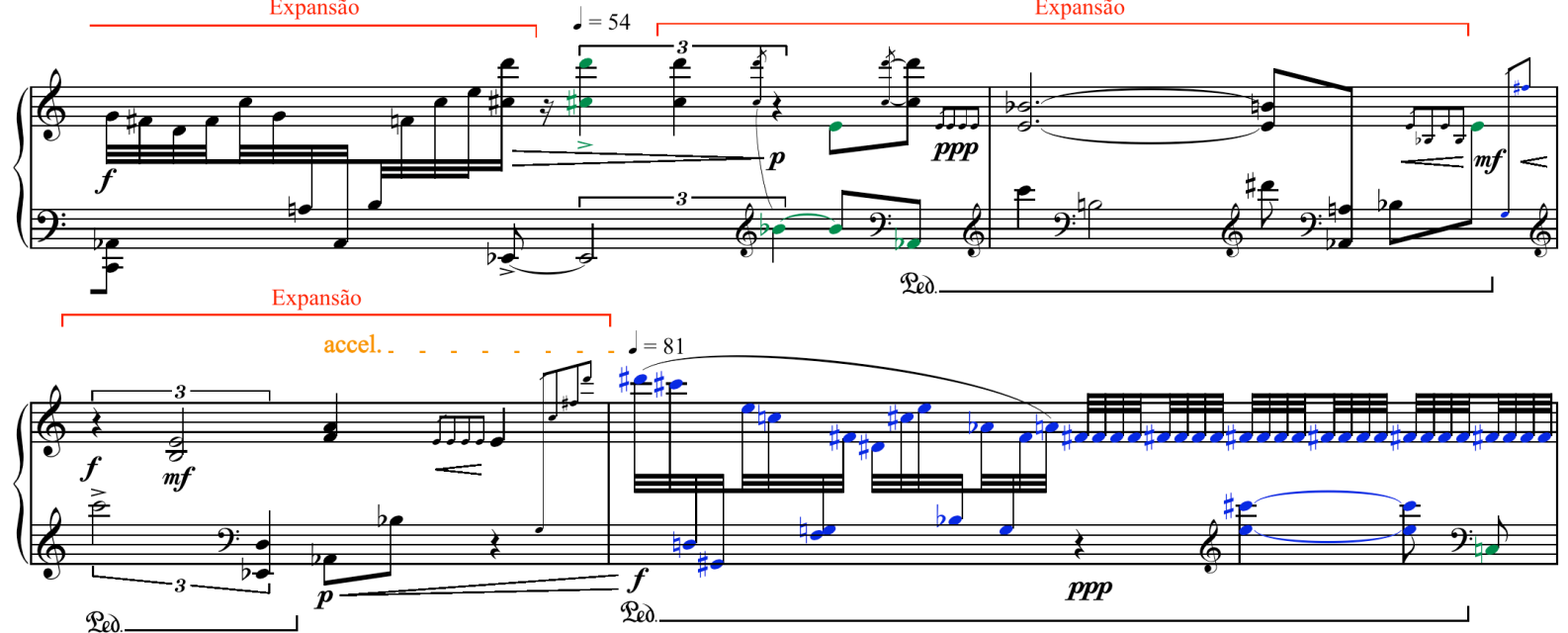

Ted

Expansão

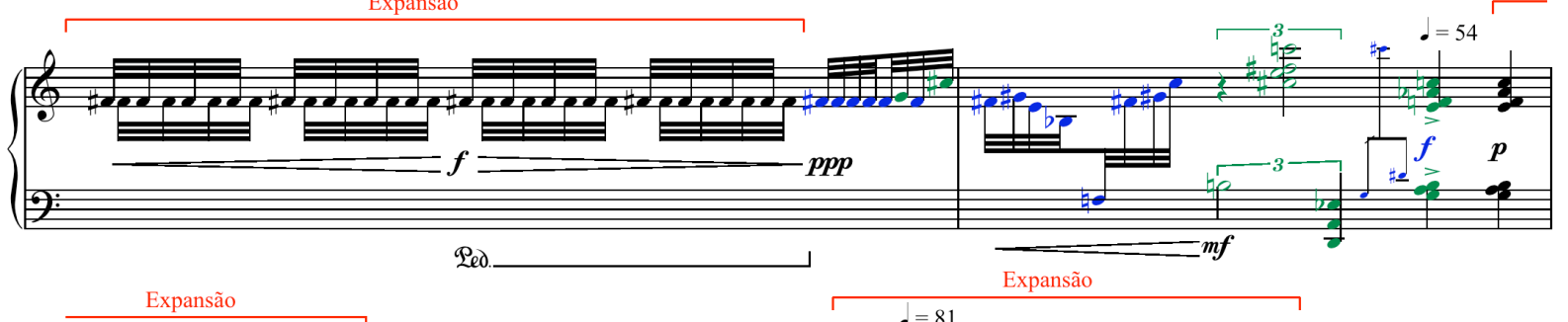

Expansão

E

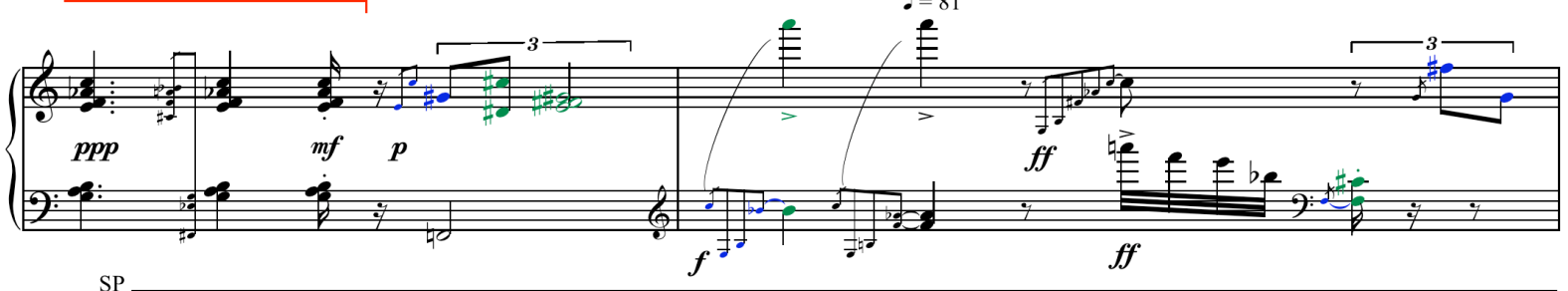

SP



Fig. 07 - Expansão de Interlinea dentro da Sonata, c.79 a c.89. 
Podemos compreender esse processo de expansão como uma digressão sobre cada um dos gestos ${ }^{37}$ apresentados em Interlinea. Além da expansão temporal dos gestos, a Sonata também propõe uma alteração de andamento para o trecho em questão: em Interlinea, o andamento é fixado em 108 bpm enquanto na Sonata, há uma oscilação entre 81 bpm e 54 bpm. A alteração de andamento somada à expansão dos gestos resulta num alargamento temporal do material de Interlinea dentro da Sonata. Enquanto em Interlinea o trecho tem duração de 28,5 tempos, na Sonata o mesmo trecho tem duração de 51 tempos. Considerando o cálculo a partir dos andamentos indicados, o trecho de Interlinea teria duração aproximada de 16 segundos enquanto na Sonata teria duração aproximada de 45 segundos. A figura a seguir ilustra essa dilatação temporal através da comparação entre os sonogramas dos trechos de Interlinea e da Sonata, extraídos a partir de gravações dos pianistas Rolf Hind e Andrea Lucchesini, respectivamente. No eixo horizontal do sonograma (parte superior da figura), lêse a duração em segundos:

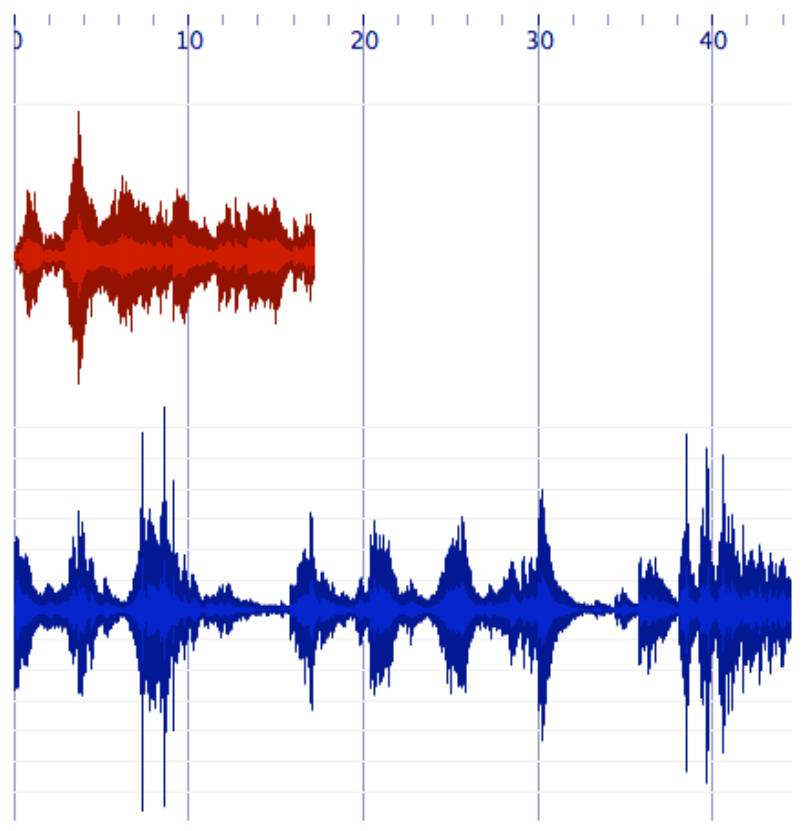

Fig. 08 - Sonogramas de Interlinea (vermelho), c.13 a c.19, e da Sonata (azul), c.79 a c.89.

37. A noção de gesto será abordada nos capítulos seguintes. 


\section{c) Derivação}

Chamaremos de derivação um terceiro recurso utilizado na Sonata. Nesse processo, o material de Interlinea aparece de maneira velada dentro da Sonata, ou seja, como uma estrutura que dá origem à construção de algum trecho mas que não se apresenta de forma explícita. Esse é o caso da correlação entre o trecho inicial de Interlinea, referido como 001 007, e seu correspondente na Sonata, referido como 065/4 - 071/3. Ao compararmos os dois trechos percebemos que há certa similaridade entre eles, porém o material de Interlinea aparece extremamente diluído na Sonata, dificultando sua identificação tanto na escuta quanto na leitura da partitura. Outra característica importante do trecho em questão (e, na verdade, da maior parte dos trechos apresentados na Sonata) é que os materiais de Interlinea aparecem combinados a uma outra camada formada pela repetição lenta e regular de uma nota $\mathrm{B}, 4$ que, como veremos no Capítulo III, se constituirá como um gesto próprio à Sonata. As figuras apresentadas a seguir mostram o trecho original de Interlinea $(001$ - 007) e seu correspondente na Sonata (065/4 - 071/3), construído através do processo de derivação. Em azul, estão marcadas as notas comuns aos dois trechos. Para facilitar sua localização, as linhas laranjas ligam as notas comuns entre Interlinea e Sonata nos quatro primeiros compassos do trecho em questão enquanto as linhas verdes desempenham a mesma função nos três compassos finais. Em certos casos, as notas de Interlinea aparecem na Sonata em registros diferentes da tessitura ou são apenas grafadas com notas enarmônicas ${ }^{38}$. Dessa maneira, como se pode perceber na figura a seguir, apesar de todas as alterações rítmicas, há um aproveitamento total das alturas apresentadas em Interlinea - e o principal, sem qualquer modificação na ordem original em que aparecem.

38. A única exceção é a quarta nota do trecho de Interlinea, um Fa\#, que na Sonata é substituída pelo ataque das notas $\mathrm{E}$, e F. 


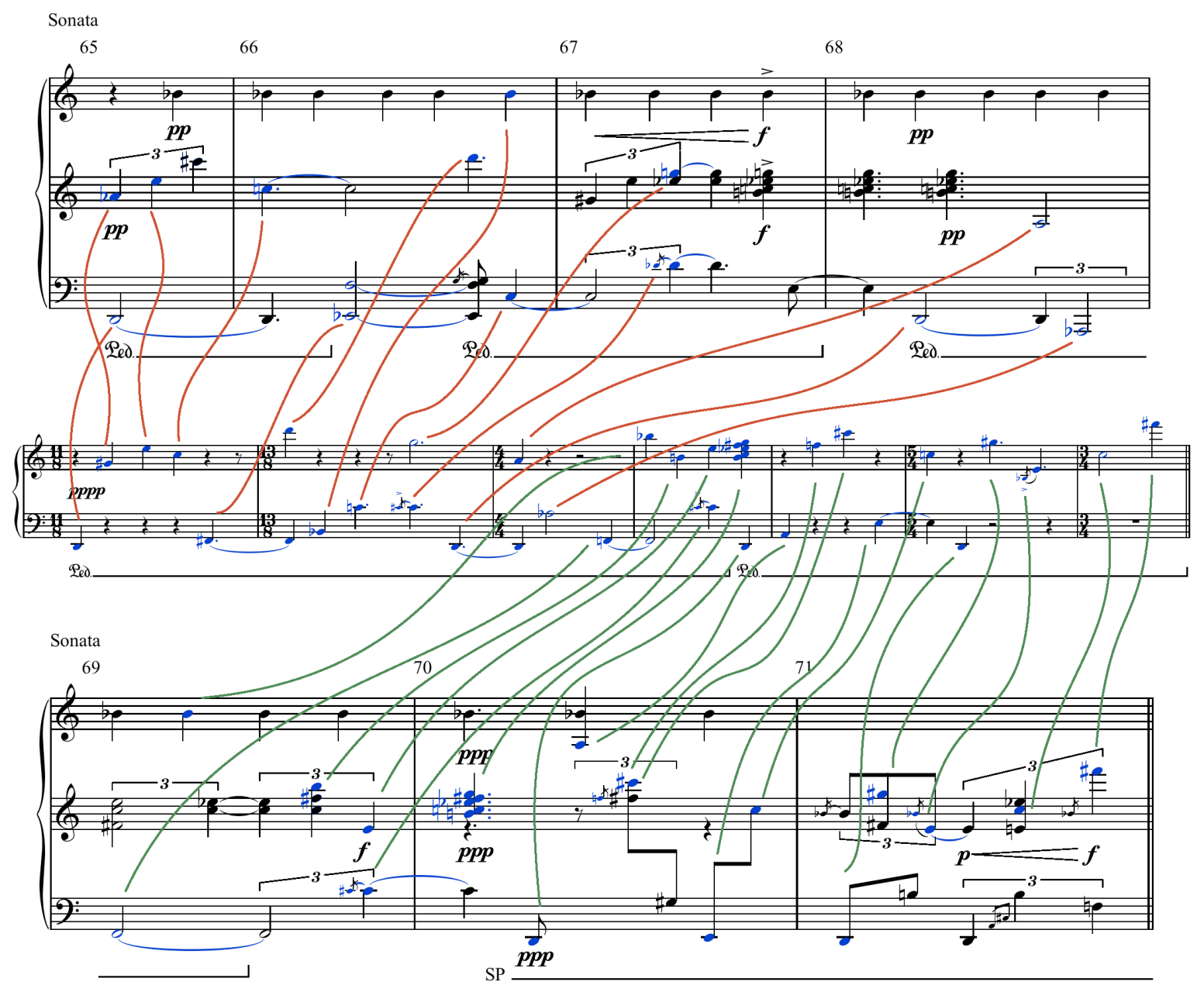

Fig. 09 - Trecho original de Interlinea, c.01 a c.07 (no centro da figura), e derivação desse trecho dentro da Sonata, c.65 a c.71.

Através de alguns exemplos, pudemos demonstrar três recursos mais utilizados por Berio no processo de reescritura de Interlinea na Sonata: citação, expansão e derivação. Esses recursos dão conta de explicar as relações entre os materiais de Interlinea e da Sonata nos trechos identificados como correlativos nos Quadros Comparativos A e B (Fig. 2 e Fig. 3, ver marcações em laranja). Porém, ainda é importante observarmos o que acontece nos trechos da Sonata que não apresentam correlação com trechos de Interlinea (ver marcações em verde no Quadro Comparativo A, Fig. 2). Observando todos os trechos marcados na cor verde no Quadro Comparativo A (Fig. 2), é possível perceber que, em muitos casos, apesar de não tratar de uma correlação direta entre as duas peças, o material musical apresentado na Sonata é bastante similar àquele utilizado em Interlinea. Trata-se, portanto, de um 
procedimento onde um ou mais elementos de Interlinea são aproveitados na Sonata, porém não exatamente um determinado trecho. Chamaremos esse processo de proliferação.

\section{d) Proliferação}

O trecho 111/3 - 128 da Sonata é um bom exemplo desse procedimento. O trecho em questão não encontra um correlativo direto dentro de Interlinea, porém ele é composto integralmente por materiais dela originados. De maneira sintética, esse trecho reúne os seguintes materiais:

- Notas repetidas em grupos de fusas. Esse material é muito utilizado tanto em Interlinea quanto na Sonata. Em Interlinea ele é apresentado pela primeira vez em c.13 e está presente em toda a extensão da peça. No Capítulo III, no mapeamento dos gestos característicos da Sonata, nomearemos esse material como gesto F.

- Melodia espalhada pela tessitura com durações lentas e regulares (em sobreposição ao material acima delimitado). Esse material é derivado daquele apresentado no início de Interlinea, entre c.1 e c.7. No Capítulo III, veremos que se trata do gesto G dentro da Sonata.

- Movimento em ziguezague em grupos de fusas. Esse material é apresentado pela primeira vez em Interlinea em c.13. No Capítulo III, veremos que se trata do gesto E dentro da Sonata. Assim como o material comentado no primeiro item - composto por notas repetidas em grupos de fusas (que chamaremos de gesto F) -, esse material também é bastante utilizado tanto em Interlinea quanto na Sonata.

- Movimento direcional em grupos de fusas. Esse material é apresentado originalmente em Interlinea com maior destaque a partir de c.49. No Capítulo III, veremos que se trata do gesto D dentro da Sonata, que dialogará, em geral, com os gestos E e F. 
$\mathrm{Na}$ proliferação, portanto, um ou mais materiais apresentados em Interlinea aparecem variados e combinados de diferentes maneiras dentro da Sonata. Nesse procedimento, ao contrário dos mapeados anteriormente, não é possível indicar um trecho específico de origem para traçar uma comparação "compasso-a-compasso" entre as duas peças, mas sim um material (que futuramente chamaremos de gesto) que é comum a ambas.

O recurso de proliferação dá conta de recuperar a origem de grande parte dos trechos identificados na cor verde do Quadro Comparativo A (Fig. 2), isto é, aqueles trechos da Sonata que a princípio não apresentavam correlações diretas com qualquer trecho de Interlinea. Assim, grande parte desses trechos são resultado de um processo de proliferação de gestos apresentados originalmente em Interlinea e reelaborados de maneira mais complexa dentro da Sonata. Porém, como veremos nos capítulo seguintes, a Sonata também conta com alguns materiais que são próprios a ela (como será o caso dos gestos $\mathrm{C}$ e $\mathrm{Z}$ que comentaremos no Capítulo III), bem como por outros que são derivados por diferentes combinações gestuais (como veremos no Capítulo IV). 
capítulo III - gesto 


\section{IIIa. sobre a noção de gesto em Berio}

Em seu artigo Luciano Berios's Sonata per piano forte solo or The disclosures of a sketch page, um dos poucos dedicados ao comentário analítico da Sonata, Reinhold Brinkmann sintetiza alguns aspectos da peça a partir da análise de uma página de rascunho, pertencente à Collection Luciano Berio, que integra o acervo da Paul Sacher Foundation, em Basel, Suíça. Essa página de rascunho mostra um pouco do trabalho pré-composicional de Berio, principalmente no que se refere à organização das alturas no início da peça. Em seu artigo, Brinkmann ocupa-se essencialmente em identificar nesse rascunho como Berio teria gerado algumas estruturas harmônicas a partir de uma coleção inicial de notas apresentada no topo da página de rascunho. No fim de seu texto, Brinkmann faz uma breve menção à estrutura formal da Sonata, a partir da leitura de uma outra página de rascunhos (esta, infelizmente não copiada em seu artigo), onde estaria esboçado, de maneira esquemática, o início da peça. Segue abaixo a transcrição desse trecho inicial realizada por Brinkmann ${ }^{39}$ : 


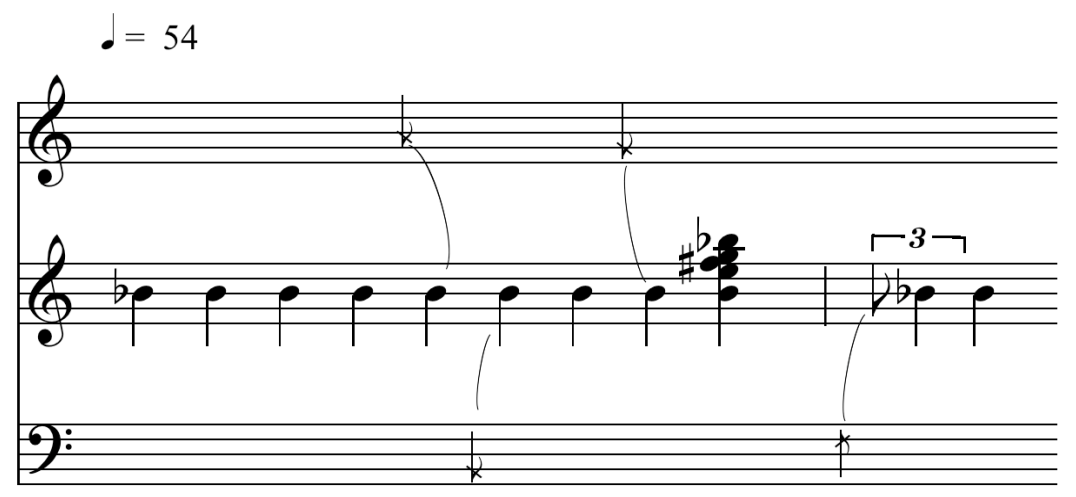

Fig. 10 - Transcrição de um trecho do rascunho da Sonata de Berio realizada por Brinkmann.

Observando esse esquema inicial anotado por Berio e comparando-o à versão final da Sonata, Brinkmann conclui:

A primeira entrada dos acordes e seu relacionamento com o $\mathrm{B}$, é reveladora. Ainda que o seu lugar, sua posição rítmica e seu caráter ornamental enquanto "grace chords", estejam lá, o conteúdo harmônico dos acordes ainda está faltando. A importante conclusão é que: esta é uma música onde gesto é mais importante que alturas e harmonia. [...] Esta observação confirma que a categoria formal central que governa a escrita vocal e teatral de Berio: o gesto, é também uma chave para a compreensão de sua música instrumental da maturidade (BRINKMANN, 2005, p. 485) ${ }^{40}$.

A categoria de gesto tem sido recorrentemente utilizada na bibliografia musical mais recente, com diferentes enfoques. Entre as abordagens mais comuns, encontram-se: aquelas que se fixam sobre a relação entre gesto e movimento corporal - gesto do intérprete sobre o instrumento, ação física -, diretamente ligadas a aspectos da técnica instrumental (também há aqui uma vasta bibliografia dedicada à música produzida com auxílio de diferentes interfaces analógicas ou digitais); aquelas que se ocupam em aproximar as noções de gesto e de signo - gesto enquanto elemento de significação, que está em lugar de algo -, principalmente a partir de leituras que se apóiam na semiótica; e ainda aquelas que compreendem por gesto as marcas características de um determinado período, estilo ou autor - gesto como entidade publicamente identificada, como personagem historicamente reconhecido -, definindo territórios e léxicos específicos.

40. "Revealing is the first entry of chords and their relationship to the sustained $\mathrm{B}$,. Whereas their place, their rhythmic position, their ornamental character as "grace chords" all are there, the pitch content of the chords is still missing. The important conclusion: this is a music where gesture is more important than pitch and harmony. [...] This observation confirms that the central formal category which governed Berio's vocal and theatrical writing: gesture, is also a key to the understanding of his mature instrumental music". 
Na bibliografia analítica de peças Berio é freqüente o uso da noção de gesto compreendida dentro desses termos. Nas Sequenze (1958-2002), por exemplo, há um forte apelo à fisicalidade do gesto, explorando em profundidade a relação entre intérprete e instrumento que resulta num virtuosismo (compreendido em novos termos) latente ${ }^{41}$. Já nos trabalhos para voz ou naqueles que se relacionam com a teatralidade, a noção de gesto ganha força enquanto signo, enquanto elemento que remete a escuta a significados externos ao discurso musical, como é o caso explícito da Sequenza III (1965), que trabalha intencionalmente com comportamentos vocais codificados ${ }^{42}$. Finalmente, em composições como Ballo e La donna ideale, que utilizam traços típicos do folclore italiano, a noção de gesto aflora enquanto marca característica de um determinado estilo ${ }^{43}$. Porém, na Sonata per pianoforte, Brinkmann se refere à idéia de gesto como categoria formal, isto é, compreendida dentro do campo da criação e da análise musical, como elemento de estruturação e inflexão da forma. Assim como o motivo poderia ser considerado o gérmen formal em peças de Brahms, por exemplo, também o gesto apareceria em Berio como elemento capaz de agenciar a forma musical.

Segundo Osmond-Smith (1991, p. 40), a noção de gesto musical passou a ser importante para Berio a partir do final dos anos 50. Data de 1961 a redação do ensaio $D u$ geste et de Piazza Carità (1983a) no qual Berio fala sobre a importância da idéia de gesto para a criação musical. Nesse texto Berio constrói a idéia de gesto como elemento central da expressão musical. Para ele, haveria uma relação indissociável entre gesto e história ${ }^{44}$ que

41. "Além de investigar em profundidade alguns aspectos técnicos específicos, nas Sequenzas eu também tentei, por vezes, desenvolver um comentário musical sobre a relação entre virtuose e instrumento, dissociando elementos do comportamento envolvidos na performance, de modo a reconstitui-los em seguida, transformados, como unidades musicais" (BERIO, 1998, p. 8) / [“As well as investigating certain specific technical aspects in depth, in the Sequenzas I've also at times tried to developed a musical commentary on the rapport between virtuoso and instrument, disassociating elements of performing behaviour, so as to then reconstitute them, transformed, as musical unites"].

42. "A voz sempre carrega com ela um excesso de conotações. Do ruído mais insolente à música mais requintada, a voz sempre significa algo, sempre se refere a algo diferente de si mesma e cria uma vasta gama de associações. (...) Na Sequenza III a ênfase é colocada sobre o simbolismo sonoro de gestos vocais, sobre as "sombras de significado" que os acompanham, sobre as associações e os conflitos a que dão origem" (BERIO, 1998, pp. 11-12) / ["The voice always carries with it an excess of connotations. From the most insolent noise to the most exquisite song, the voice always signifies something, always refers to something other than itself and creates a vast range of associations. (...) In Sequenza III the emphasis is placed on the sound symbolism of vocal gestures, on the 'shadows of meaning' that accompany them, on the associations and conflicts to which they give rise"].

43. Ballo e La donna ideale foram escritas em 1947 e integram o ciclo de canções Folk Songs (1964). As Folk Songs são um conjunto de onze canções populares de várias origens (Armênia, Estados Unidos, França etc) arranjadas para mezzosoprano e grupo de câmara. Porém, as canções Ballo e La donna ideale não são canções folclóricas originais mas sim compostas por Berio a maneira de e, por isso, são um bom exemplo de manipulação do parâmetro gestual enquanto marca idiomática.

44. Aqui é preciso compreender um duplo sentido no emprego da noção de "história". Quando Berio fala de uma 
conferiria ao gesto um potencial comunicativo. A partir dessa constatação, Berio aponta uma aproximação entre as categorias de gesto e signo. Tal qual o signo, no gesto é possível encontrar uma dimensão sintática, semântica e pragmática. Porém, Berio aponta que enquanto o signo significa, o gesto exprime: "O gesto, portanto, pode também ser o signo que se faz expressão" (1983a, p. 42) ${ }^{45}$. Para explicar melhor a distinção entre signo e gesto, Berio faz ainda uma aproximação entre as idéias de gesto e de mito. Segundo Berio, é a presença do mito que marca a distinção entre signo e gesto: tal qual o mito, o gesto não significa mas exprime. Apesar de depositar sobre a noção de mito a responsabilidade de ser o elemento essencial para distinção entre gesto e signo (ou de aproximação entre gesto e mito), Berio não desenvolve essa idéia em seu texto e permite que ela acabe pairando sobre toda a questão de maneira um tanto enigmática. De acordo com a nossa compreensão, a aproximação entres as noções de gesto e de mito resvala na maneira como ambos são estruturados: tal qual o mito, o gesto se apresenta como uma rede de sentidos, como composto, como estrutura complexa e condensada. Haveria, portanto, um paralelo entre a percepção do mito e do gesto tanto no que se refere à sua estrutura - na medida em que ambos conjugam múltiplas dimensões - quanto à sua relação com a percepção - como expressão imanente. Para Berio, se um gesto é esvaziado de suas estruturas intermediárias, ele tende a se degenerar em símbolo, em estrutura codificada e cristalizada, onde a expressão cai ao nível da comunicação banal. Por isso, para Berio, será fundamental manter o gesto como estrutura suficientemente aberta, capaz de se remodelar segundo cada contexto. Assim, em Berio, o gesto seria um elemento bem delimitado, porém aberto, de estrutura complexa (composta por diversas estruturas intermediárias), que carrega um potencial comunicativo e expressivo.

A noção de gesto também foi tratada do ponto de vista composicional por Brian Ferneyhough, em especial nos artigos Form-Figure-Style: An intermediate assessment e Il tempo della figura, publicados no início da década de 80. Em Ferneyhough, a idéia de gesto aparecerá, em princípio, em chave negativa para, num segundo momento, combinado com as noções de figura e textura, aparecer em chave positiva. Segundo Silvio Ferraz ${ }^{46}$, Ferneyhough compreende o gesto como representação: "ele substitui um fato por um conceito" (FERRAZ, 1998, p. 169). O gesto é genérico e por isso "não sobrevive do detalhe, das nuanças do som,

história do gesto, ele se refere tanto à construção e manifestação de um gesto específico ao longo da história da música (History) - e por isso, para Berio, um gesto só pode ser "feito" e não "inventado" - como à construção e manifestação de uma história local de um determinado gesto, restrita ao espaço-tempo de uma composição específica (story).

45. "Le geste, donc, peut aussi être le signe qui s'est fait expression".

46. Em seu livro Música e Repetição (1998) e em correspondência direta com a autora em julho/2010. 
mas sim daquilo que nele é habitual e comum" (FERRAZ, 1998, p. 169). O gesto afirma constantemente sua identidade e, portanto, não abarca grandes modulações. Se se altera muito o gesto, ele se perde e vira outro gesto. A princípio, segundo Ferneyhough, o gesto operaria, portanto, como símbolo, como elemento representativo, convencional, de superfície. A partir dessa definição de gesto, Ferneyhough apresentará a idéia de figura. A figura, ao contrário do gesto, sobreviveria das nuanças, das relações e transformações de seus componentes. A um caráter supostamente rígido do gesto, Ferneyhough contrapõe a maleabilidade da figura:

Um gesto, cujas características componentes definidoras apresentam uma tendência a escapar daquele contexto específico para se tornar radicais significantes independentes, livres para se recombinarem, para se solidificar em outras formas gestuais, pode ser chamado, por falta de outra nomenclatura, de figura. (FERNEYHOUGH, 1993a, p. 37) ${ }^{47}$.

Porém, não se trata de averiguar duas categorias distintas dentro da composição mas sim duas maneiras diferentes de observar um mesmo objeto musical. Sendo essas categorias ligadas à percepção, elas se dão no tempo e atuam em simultaneidade: "Vistas como territórios de escuta, elas são contemporâneas e coexistem envolvendo-se umas às outras" (FERRAZ, 1998, p.179). Assim, todo gesto tem uma figura: a figura do gesto. E todo gesto, portanto, se concretiza em figuras: o gesto na figura. A figura é portadora do gesto e vice-versa. Para Ferneyhough, é o trabalho realizado sobre a figura que permitirá a não cristalização dos gestos, impedindo que estes se convertam em mera simbologia.

É por isso que ele [Brian Ferneyhough] vai propor uma outra forma de tratar o gesto, não mais como uma entidade que se remeta a uma referencialidade externa a seus próprios constituintes; mas tomando estes mesmos elementos como uma potência criativa para gerar infinitamente novos gestos e novas expressões, fazendo-os vivenciarem também, cada subcomponente individual, o seu próprio tempo: "o tempo das figuras". (KOZU, 2002, p. 49).

A tricotomia de Ferneyhough inclui também a noção de textura. Segundo Ferraz, a textura seria uma sensação tátil-sonora produzida pelo movimento das figuras. Assim, a textura seria o aspecto mais concreto na escuta. A mudança de sua constituição interna não gera uma variação de textura, mas sim uma nova textura. Nesse sentido, Ferraz aponta que "sendo irredutível, a textura pode ser vista como o primeiro elemento da percepção musical e,

47. "A gesture whose component defining features display a tendency towards escaping from that specific context in order to become independently signifying radicals, free to recombine, to "solidify" into further gestural forms may, for want of other nomenclature, be termed a figure". 
por conseguinte, o último, ou melhor, o resultado da sobreposição dos elementos numa composição musical" (FERRAZ, 1998, p. 166). A partir dessa dessa perspectiva, que compreende a tripartição gesto-figura-textura como “"pontos de vista' diferentes que permitem observar um 'objeto musical'” (COURTOT, 2009, p. 61) ${ }^{48}$, a idéia de gesto aparecerá em Ferneyhough em chave positiva. De maneira sintética, Courtot resume o que seria, então, a idéia de gesto em Ferneyhough:

O gesto é uma concreção altamente energética de estratos paramétricos, cujas qualidades internas devem ser ligadas a outros gestos a fim de evitar que ele seja percebido enquanto referencial, autosuficiente, e muito expressivamente conotado. Ele não é uma entidade abstrata, seu caráter concreto se exprime num timbre instrumental e no idiomatismo de uma escritura para um instrumento (ou um grupo de instrumentos). Ele possui valores paramétricos e uma "significação", mas também uma força expressiva (COURTOT, 2009, p. 75) ${ }^{49}$.

Ainda segundo Courtot (2009, p. 63), "um gesto forma portanto uma Gestalt, uma micro-forma musical, cuja característica principal, em Ferneyhough, é o aspecto explosivo"


intermediário da composição, estando entre a combinação propriamente paramétrica e a definição do esquema formal: "sem esse nível intermediário, o nível paramétrico permanece estéril, e os níveis extremos (parâmetros e forma) não podem comunicar” (COURTOT, 2009, p. 61$)^{51}$.

Apesar de Ferneyhough não se referir ao ensaio de Berio em seus textos, é possível identificar diversos pontos comuns entre $\operatorname{ambos}^{52}$. O que difere os dois trabalhos é, de fato, o momento histórico dos dois compositores: enquanto para Berio era importante criar um caminho tangencial à escola de Darmstadt, para Ferneyhough alguns valores do serialismo integral voltariam a ganhar força ${ }^{53}$. Berio propõe a idéia de gesto como elemento capaz de

48. "'Points de vue' différents qui permettent d'observer un 'objet musical"'.

49. "Le geste est une concrétion hautement énergétique de strates paramétriques, dont les qualités internes doivent être reliées à d'autres gestes afin d'éviter qu'il soit perçu comme référentiel, autosuffisant, et trop expressivement connoté. Il n'est pas une entité abstraite, son caractère concret s'exprimer dans un timbre instrumental et dans l'idiomatisme d'une écriture pour un instrument (ou un groupe d'instruments). Il possède des valeurs paramétriques et une 'signification' ainsi qu'une force expressive".

50. "Un geste forme donc une Gestalt, une micro-forme musicale, dont le caractère principal, chez Ferneyhough, est l'aspect explosif".

51. "Sans ce niveau intermédiaire, le niveau paramétrique demeure stérile, et les niveaux extrêmes (paramètres et forme) ne peuvent communiquer".

52. Para uma abordagem comparativa mais detalhada a respeito da noção de gesto em Berio e Ferneyhough, ver CASTELLANI, 2010.

53. Segundo Fernando Kozu a New Complexity - que tem sua "fundação" atribuída a Ferneyhough, ainda que a 
recuperar o sentido comunicativo das obras que teria, de certa forma, sucumbido ao caráter esotérico do serialismo integral. Ferneyhough está inserido em um novo debate, sob uma perspectiva inversa à de Berio. Em seus textos, escritos 20 anos após o ensaio Du geste et de Piazza Carità de Berio, Ferneyhough ocupa-se em elencar e distinguir categorias para que possa endereçar sua crítica a compositores que, presos a uma suposta supremacia do gesto, estariam produzindo peças que revelavam apenas um trabalho de superfície. O debate de Ferneyhough é com tendências como a New Simplicity e a Neue Romantik. Segundo Castellani (2010, p. 4), "tais tendências tratavam o gesto musical como uma mônada expressiva, carregando diversos significados semânticos específicos, servindo apenas como um veículo para comunicar algo preestabelecido [...]". É essa diferença de contexto dos dois compositores que fará com que em Berio a noção de gesto apareça em chave positiva e em Ferneyhough, a princípio, negativa. Porém, vale ressaltar que para Ferneyhough não se trata de perder a dimensão do gesto mas sim de colocá-lo diante de um processo de constante reelaboração - função esta que seria desempenhada pela figura. De certa maneira, algo similar já havia sido comentado por Berio (1983a) ao enfatizar a necessidade de cuidados inerentes ao trabalho gestual, alertando sobre o perigo de o gesto degenerar em símbolo caso sua dimensão mítica fosse esvaziada, isto é, caso se abrisse mão de trabalhar sobre o que naquele momento o compositor chamou de estruturas intermediárias. Assim, de maneira sintética, o que se tem é: por um lado, Berio propondo a noção de gesto como chave para recuperação de sentido; e por outro lado, Ferneyhough propondo a noção de figura como chave para recuperação da própria categoria de gesto que havia sido autonomizada e reduzida a mera simbologia. Portanto, apesar de elaboradas em momentos muito distintos, as noções de gesto dos dois autores são complementares.

A partir da leitura dos textos de Berio e Ferneyhough, além de uma bibliografia complementar ${ }^{54}$ mais recente sobre o assunto, é possível destacar três qualidades recorrentes que parecem marcar a categoria de gesto. Uma primeira recorrência é a idéia de que o gesto é $\underline{\text { movimento, }}$ ele tem começo, meio e fim. Ele implica um deslocamento temporal bem delimitado, isto é, ele imprime sua trajetória. Uma segunda recorrência é a idéia de que o

contragosto - teria surgido na esteira da vanguarda serial. Amparado pelo texto Prehistory: Modernism, Postmodernism and Music, de Georgina Born (1995), Kozu afirma que "é possível demarcar também uma genealogia da complexidade atrelada às três fases do serialismo implícitas no estudo de Born, a saber: $1^{\mathrm{a}}$ fase pré-serialismo (pré-complexidade); $2^{\mathrm{a}}$ fase - serialismo integral (complexidade); $3^{\mathrm{a}}$ fase - pós-serialismo (nova complexidade)." (KOZU, 2003, p. 16).

54. ALDROVANDI (2000), CASTELLANI (2010), COURTOT (2009), FERRAZ (1998), HATTEN (2004), IAZZETTA (1996, 1999), SOUZA (2004) e ZAGONEL (1992). 
gesto musical carrega uma energia, ou seja, ele condensa uma potência, uma efervescência, que se realiza quando o gesto de desenrola, quando cumpre sua trajetória. Além da idéia de trajetória e de energia, para ser compreendido como gesto, um determinado elemento precisa se mostrar significativo, ou seja, é necessário que ele tenha uma personalidade bem definida e que expresse algo, que manifeste seu aspecto semântico e adquira sentido musical. Reunindo essas três qualidades podemos sintetizar a noção de gesto, no contexto específico desse trabalho, como um fluxo energético expressivo.

Uma última qualidade intrínseca à noção de gesto, porém que se manifesta, em geral, somente na bibliografia que trata o gesto dentro do campo da criação musical, é o seu caráter processual. Tanto Berio quanto Ferneyhough falam de gesto como uma estrutura aberta, isto é, como um elemento capaz de se remodelar segundo cada contexto. Nos dois autores, é fundamental o estabelecimento de um processo de construção e desconstrução permanente dos gestos no interior de cada obra ${ }^{55}$.

Para ser criativo, o gesto deve poder destruir qualquer coisa, ele deve ser dialético e não deve se privar de seu "teatro", mesmo ao preço de se sujar como diria E. Sanguineti - na lama, na palus putredini da experiência. Isto quer dizer que ele deve poder conter sempre um pouco daquilo que ele se propõe a ultrapassar (BERIO 1983a, p. 45) ${ }^{56}$.

Compreendido nesses termos, o gesto seria, segundo Berio, um elemento essencial para a constituição da poética de um autor:

[...] Uma poética sem gestos reais é como uma linguagem sem inflexões vocais e sem a experiência sensível de seus materiais: sem um futuro e sem conflitos. Ela se assemelha à idéia de uma linguagem-alfabeto, de uma linguagem-nomenclatura, ou de uma música fundada somente sobre as notas e não sobre o som e sobre os gestos da execução e da escuta (mesmo com todas as suas contradições) (BERIO, 1983a, p. 43) ${ }^{57}$.

55. Em Ferneyhough, essa propriedade processual do gesto será ilustrada através da idéia de porosidade (Cf. COURTOT, 2009, p. 64).

56. "Pour être créateur, le geste doit pouvoir détruire quelque chose, il doit être dialectique et ne doit pas se priver de son 'théâtre', même au prix de se souiller - comme dirait E. Sanguineti - dans la fange, dans la palus putredinis de l'expérience. C'est-à-dire qu'il doit pouvoir contenir toujours un peu de ce qu'il se propose de dépasser".

57. "[...] Une poétique sans gestes réels est comme un langage sans inflexions vocales et sans l'expérience sensible de ses matériaux: sans un avant et sans conflits. Elle est semblable à l'idée d'un langage-alphabet, d'un langage-nomenclature, ou d'une musique fondée seulement sur des notes, et non sur le son et sur les gestes de l'exécution et de l'audition (même avec toutes leurs contradictions)". 


\title{
IIIb. gesto na Sonata
}

\begin{abstract}
A Sonata per pianoforte de Berio é construída a partir de um número limitado de gestos que são introduzidos paulatinamente durante os minutos iniciais da peça. Num primeiro momento, esses gestos são apresentados de maneira bastante individualizada, distanciados entre si através da inserção de silêncio ${ }^{58}$, gerando um discurso inicial fraturado, isto é, sem continuidade entre os diferentes gestos. Uma situação similar é apontada por Francis Courtot (2009) em sua análise do Quarteto de Cordas $n^{\circ} 3$ (1987) de Brian Ferneyhough. Nesse quarteto, Courtot identifica um total de 23 gestos iniciais, independentes uns dos outros. Segundo Courtot (2009, p. 244), após a apresentação inicial dos gestos, o drama do quarteto reside na capacidade de esses gestos se moldarem mais ou menos facilmente durante a peça. Como será demonstrado adiante, a Sonata de Berio configura um jogo dramático que, em parte, se assemelha ao proposto por Ferneyhough no seu terceiro quarteto de cordas. Para compor esse jogo dramático, Berio estrutura, no início da Sonata, oito gestos com características muito peculiares e distintas. A seguir veremos como cada um deles é estruturado. Para melhor identificação de cada um dos gestos usaremos um sistema
\end{abstract}

58. Como veremos adiante, não se trata de um silêncio efetivo, pois a apresentação dos gestos de $\mathrm{A}$ a $\mathrm{G}$ é constantemente assistida pelo gesto $\mathrm{Z}$, a saber, uma nota $\mathrm{B}, 4$ repetida lentamente. 
fixo de cores durante os três capítulos seguintes. Dessa maneira, cada um dos gestos estará sempre identificado com uma mesma cor. A figura a seguir apresenta a relação de cores que serão utilizadas:

\begin{tabular}{|c|c|c|c|}
\hline Gesto Z & roxo & Gesto D & marinho \\
\hline Gesto A & turquesa & Gesto E & verde \\
\hline Gesto B & amarelo & Gesto F & laranja \\
\hline Gesto C & rosa & Gesto G & cinza \\
\hline
\end{tabular}

Fig. 11 - Relação entre cores e gestos.

\section{$\underline{\text { Gesto Z }}$}

$\mathrm{O}$ gesto $\mathrm{Z}^{59}$ é caracterizado pela repetição lenta e regular de uma mesma nota, mais especificamente, de um $\mathrm{B}, 4^{60}$, que tem sua ressonância garantida pelo uso do pedal tonal. A figura abaixo mostra a primeira aparição do gesto $\mathrm{Z}$ na peça:



Fig. 12 - Gesto Z em c.1 a c.3.

59. Os gestos serão nomeados por ordem de aparição na peça, partindo da letra A. Esse gesto, porém, por constituir, inicialmente, uma camada independente que assistirá a introdução dos demais gestos, será nomeado Z . 60. Será adotado o sistema americano para nomenclatura das alturas no qual a nota la do diapasão é grafada como A4 (cf. LLOYD; RASTALL, in SADIE, 2001, vol. 19, p. 806). 
$\mathrm{O}$ gesto $\mathrm{Z}$ não aparece em Interlinea e, portanto, é um material próprio à Sonata. $\mathrm{O}$ gesto $\mathrm{Z}$ pode ser descrito como um elemento de repetição que evoca a sensação de permanência e estabilidade. Em torno dele serão articulados os demais gestos da peça. Segundo Brinkmann (2005, p. 481), "sua função é tanto servir como fator unificador e manter a integridade da peça, quanto formar uma oposição dramática com os eventos que o cercam"61. Assim, o gesto Z compartilha certas característica com a idéia de ostinato. Segundo o verbete do The New Grove, ostinato é "um termo usado para se referir à repetição consecutiva de um padrão musical enquanto outros elementos estão em transformação"


maneiras ao longo da história da música. Como elemento destinado ao baixo, foi bastante utilizado no período Barroco, em peças como o madrigal Zefiro Torna, de Monteverdi, ou como o afamado Canon em Re, de Pachelbel. A passacaglia, uma estrutura baseada num ostinato harmônico, foi também muito utilizada no Barroco e em outros momentos da história da música, como no quarto movimento da Sinfonia $n^{\circ}$ 4, Op. 98, de Brahms, ou em Nacht, canção do Pierrot Lunaire, de Schoenberg, ou ainda na própria Passacaglia, Op. 1, de Webern. Podendo ainda ser compreendido como gesto inerente ao tema com variações, as 32 Variações em $\mathrm{Cm}$ de Beethoven, pela compactação e simplicidade de seu tema e de sua harmonia em oito compassos, gera uma escuta muito clara do ostinato harmônico. Já a Berceuse, Op. 57, de Chopin, traz uma maneira diferenciada de trabalhar o ostinato, realizando um pêndulo constante entre dois acordes. A idéia de ostinato está presente também na música dodecafônica, em casos onde a série é trabalhada como tema, e também na música e Stravinsky, firmando-se muitas vezes em camadas intermediárias da textura. Mesmo dentro da obra de Berio, a idéia de ostinato é recorrente (como na Sequenza VII, para oboé, por exemplo). Entre tantos exemplos, uma referência mais próxima à Sonata de Berio parece ser Le Gibet, a segunda peça de Gaspard de la Nuit, de Ravel, que também se inicia com a lenta repetição de um $\mathrm{B}$, que se consolidará como um ostinato durante toda a peça e que, de maneira similar à Sonata de Berio, será submetido à sobreposição de blocos de acordes.

61. "Its function is either to serve as unifying factor and hold the piece together, or to form a dramatic opposition to the events surrounding it".

62. "A term used to refer to the repetition of a musical pattern many times in succession while other musical elements are generally changing". 
Ravel - Gaspard de la Nuit

\section{Le Gibet}

Que vois-je remuer autour de ce Gibet? - Faust
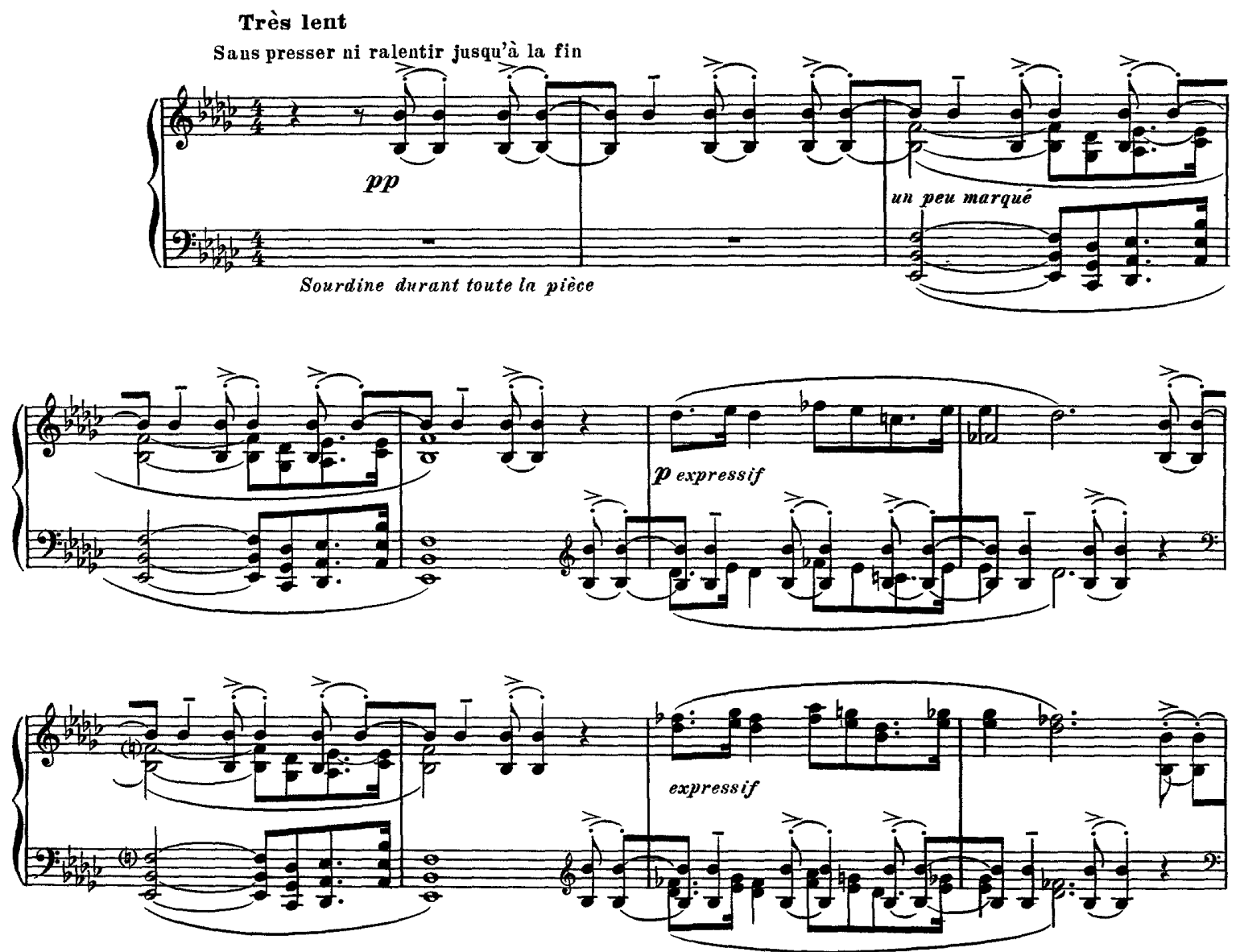

Fig. 13 - Compassos inicias de Le Gibet (1908), em Gaspard de la Nuit, de Maurice Ravel.

Lembrar dessas e de outras referências musicais caracterizadas pela presença do ostinato contribui para o esclarecimento da relação entre gesto e história proposta por Berio em Du geste et de Piazza Carità (1983a). As peças anteriormente referidas carregam o gesto do ostinato, e este, por sua vez, carrega em si a memória dessas obras. O gesto carrega uma história que se atualiza quando este se faz presente. A partir dessa perspectiva, é possível dizer que a Sonata, ao fazer uso do gesto $\mathrm{Z}$ - que compartilha de características de um gesto tão carregado de sentido como o ostinato -, insere o ouvinte numa dimensão espaço-temporal que se descola, se desprende do presente, conduzindo o ouvinte a um espaço mítico, como se flashes da história da música estivessem presentes, atravessando sua escuta. 
Porém, parece importante questionar o que significa se aproximar de um gesto de ostinato, típico do repertório tonal - justamente por se manter, em geral, como figura de fundo, exercendo o papel de "bússola" harmônica - numa obra desprovida de qualquer pretensão de revitalizar a tonalidade. O fato é que na Sonata o gesto do ostinato é refeito a partir de um novo referencial, o referencial do próprio gesto. Isso significa dizer que o gesto $\mathrm{Z}$ não se comporta somente como uma estrutura abstrata de ostinato, onde o evento sonoro é reduzido a uma mera função, por exemplo, de manutenção da coerência formal da peça ainda que essa também seja uma característica relevante (até inevitável) do gesto $\mathrm{Z}$. $\mathrm{Na}$ Sonata, o gesto Z, ao se estruturar a partir da reiteração de uma única nota, situada num registro específico, isto é, um $\mathrm{B}, 4$, coloca em evidência o som em si e agrega, assim, à sua dimensão de significação e de sentido formal, o movimento concreto do gesto, seu potencial sonoro. De maneira crítica, Berio se utiliza de um gesto historicamente catalogado atualizando-o num novo contexto. Como resultado, o que se observa na Sonata é justamente um conflito entre o gesto $\mathrm{Z}$ e os demais gestos que o cercam, fazendo com que o gesto $\mathrm{Z}$ oscile entre os planos de figura e fundo, gerando um movimento de deslocamento constante.

Como veremos adiante, o gesto $\mathrm{Z}$ integrará, junto com o gesto $\mathrm{F}$, uma família de gestos que neutraliza seu aspecto melódico através da repetição de uma mesma altura, colocando em evidência sua configuração rítmica. Esses gestos, portanto, serão caracterizados por uma textura de "pontos", em oposição às texturas de "blocos" e "linhas", que caracterizarão outros gestos.

\section{$\underline{\text { Gestos A, B e C }}$}

Nos compassos 3 e 4 é apresentado um primeiro gesto que se sobrepõe ao gesto Z. Esse novo gesto, denominado A, pode ser encontrado em Interlinea. O gesto A é caracterizado pelo ataque curto e seco (uso do staccato) de um bloco harmônico compacto (tessitura comprimida), em dinâmica pianissimo, com filtros e ressonâncias resultantes do uso do pedal tonal: 


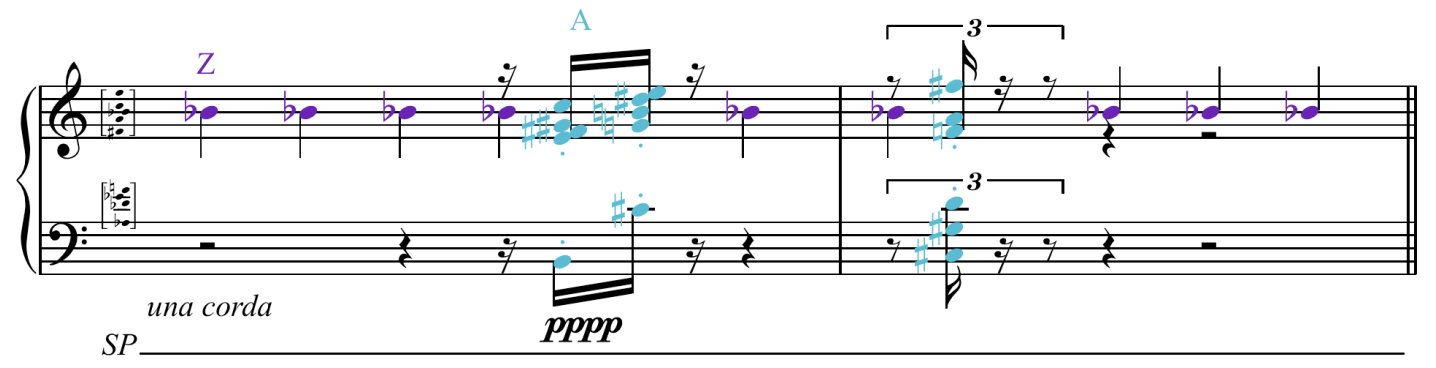

Fig. 14 - Gesto A em c.3 e c. 4 .

Nestes dois compassos é possível falar de duas figuras diferentes do gesto A: uma caracterizada pela junção das duas primeiras semicolcheias; e outra caracterizada pelo ataque individual da terceira semicolcheia. A distinção entre essas duas figuras reside no fato de que a primeira, ao encadear mais de um ataque num curto espaço de tempo, insere o gesto A num contexto de movimento direcional. Algo similar pode ser verificado em c.5 que também reúne as duas figuras comentadas. Porém, comparando c.5 com c.3 e c.4, é possível observar algumas alterações figurais, como perfil (direção melódica), densidade (quantidade de notas por acorde) e organização rítmica (posição do terceiro ataque dentro da tercina).

Além de sua relação com Interlinea, o gesto A nos remete inevitavelmente à Sequenza IV, para piano, escrita cerca de 36 anos antes. O gesto A tem grande preponderância na Sequenza IV e se apresenta com uma configuração similar àquela já comentada na Sonata: um ataque curto e seco de um bloco harmônico com dinâmica em pianíssimo.

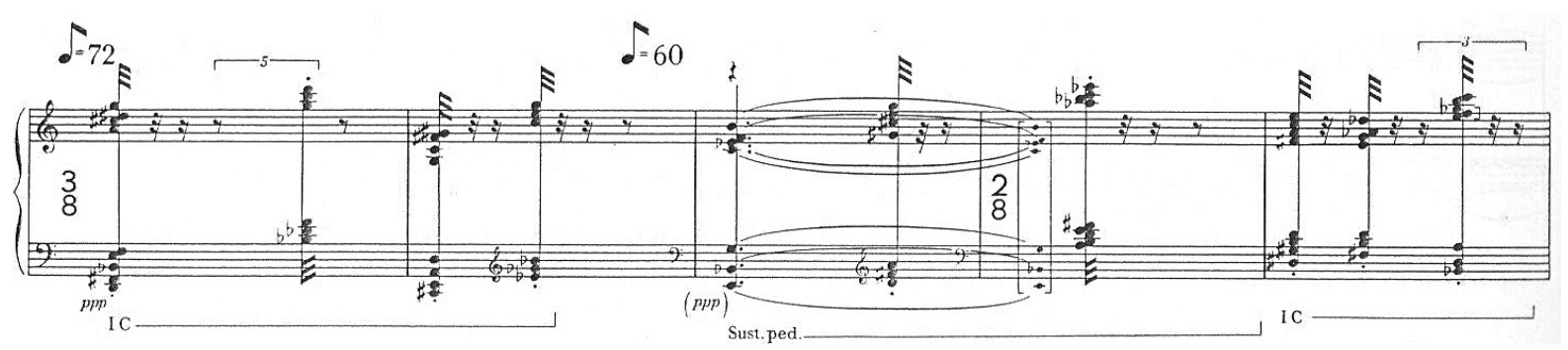

Fig. 15 - Gesto A na Sequenza IV, c.1 a c.5. 
Na Sequenza IV, Berio também faz uso do pedal tonal, porém, de uma maneira diferente. Na Sequenza IV, o pedal tonal é utilizado para sustentar um determinado conjunto de notas enquanto um segundo acorde é articulado. Intencionalmente, o segundo acorde não inclui notas pertencentes ao acorde anterior e que estejam sustentadas pelo pedal tonal. Dessa maneira, o pedal tonal possibilita a sobreposição de diferentes harmonias dentro da Sequenza $I V$. Na Sonata o uso do pedal tonal é um pouco mais elaborado: ele não só sobrepõe diferentes harmonias como também cria uma polifonia dentro de cada um dos acordes na medida em que algumas notas são comuns àquelas sustentadas pelo pedal tonal e outras não. Na Fig. 14, por exemplo, o primeiro ataque do gesto A possui três notas curtas $(\mathrm{B} \sharp, \mathrm{E} \sharp \mathrm{e} G \sharp)$ e duas notas com ressonância prolongada pelo uso do pedal tonal ( $\mathrm{F} \# \mathrm{e} C \mathrm{C} \sharp)$.

Outra referência importante do gesto A dentro da própria obra de Berio é Leaf, escrita em 1990, que integra o conjunto de Six Encores. Essa peça curta, com cerca de 1'20" de duração, é inteiramente construída sobre o gesto que na Sonata chamamos de A. Nessa peça, o pedal tonal opera de maneira similar à Sonata.

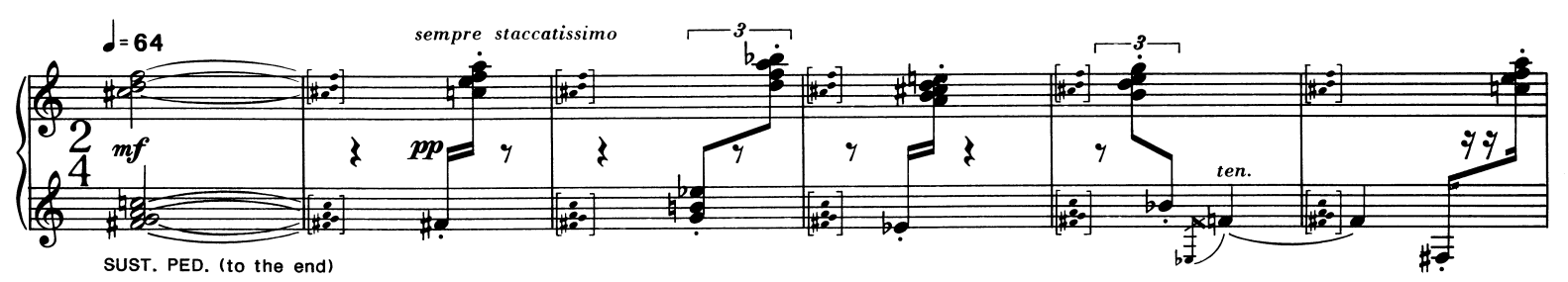

Fig. 16 - Gesto A em Leaf, c.1 a c.6.

De volta à Sonata, um novo gesto surge no quarto tempo de c.6 (Fig. 17). Este gesto, denominado B, também está presente em Interlinea e guarda certa semelhança com o gesto A por ainda tratar de um ataque de bloco harmônico com tessitura compacta. Porém, o gesto B é sustentado por um tempo maior e não apresenta aquela articulação em staccato, típica do gesto A. A princípio, o gesto B não possui características tão peculiares quanto os demais gestos. De maneira geral, ele não é nada além de um acorde com uma duração maior do que o gesto A, o que dificulta inclusive sua compreensão enquanto gesto. Nesse caso, não faria sentido, por exemplo, tentarmos mapear traços do gesto B ao longo da história da música ou mesmo na própria obra de Berio, como fizemos com os gestos $\mathrm{Z}$ e A. Porém, é o contexto 
onde ele se insere, isto é, sua posição dentro da Sonata, que faz com que o gesto B possa de fato assumir o papel de gesto. É em oposição ao gesto A que o gesto B ganha força dentro da peça. Isso pode ser percebido claramente com o recurso utilizado por Berio para introduzir o gesto B. Em c.6, o gesto B aparece imediatamente depois do gesto A, incorporando todas as notas por ele apresentadas. Numa primeira escuta, é como se o acorde atacado pelo gesto A tivesse sido sustentado pelo pedal tonal e reverberasse dentro do gesto B. O gesto B, portanto, nasce de dentro do gesto A e estabelece com ele um jogo de oposição (ou complementação). $\mathrm{Na}$ figura a seguir é possível notar ainda duas variações do gesto B apresentadas logo no início da peça: em c.8, o gesto B é acrescido da variante arpejo, enquanto em c.13, ele é alterado pela variante apojatura.
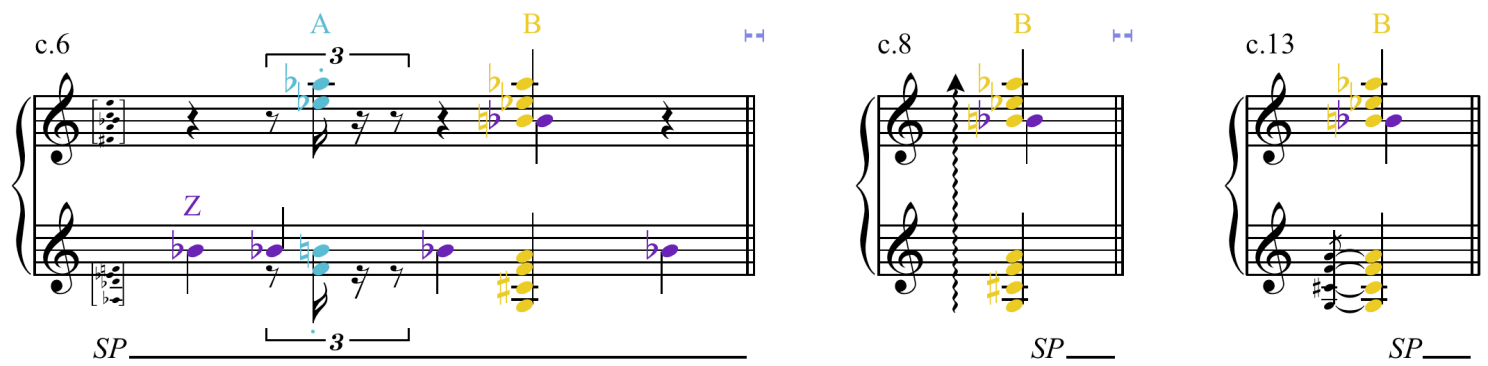

Fig. 17 - Gesto B em c.6, c.8 e c.13.

Até c.11 a peça constrói um ambiente caracterizado por uma sonoridade etérea, resultante tanto da contenção da dinâmica em pianíssimo quanto do uso do pedal tonal, que mantém um rigoroso controle sobre as ressonâncias do piano. Porém, no primeiro tempo de c.12 observamos a constituição de um novo gesto que modifica drasticamente a sonoridade inicial da peça. Esse gesto, denominado C, apresenta-se de maneira abrupta, com dinâmica ff e reverberação ampliada pelo uso do pedal de sustentação, não utilizado até então. O gesto C, caracterizado por um fluxo de acordes em movimento rápido, não está presente em Interlinea e por isso, da mesma maneira que o gesto $\mathrm{Z}$, configura-se como um material próprio à Sonata. 


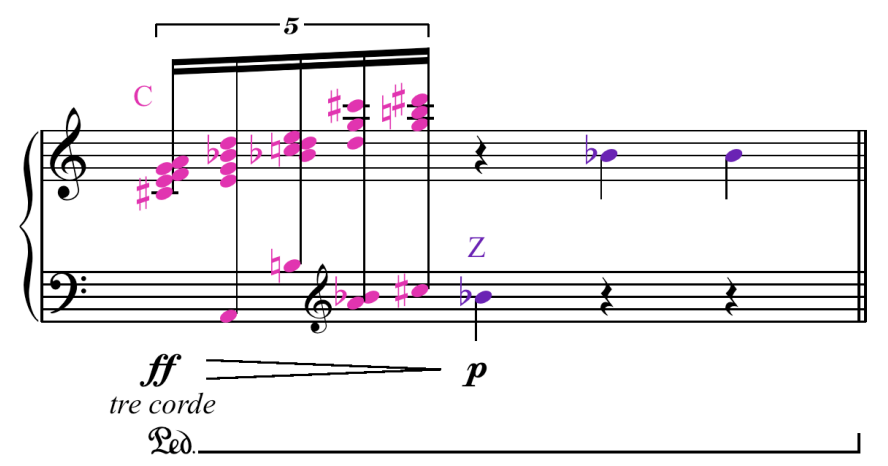

Fig. 18 - Gesto C em c. 12.

Poucos compassos depois podemos observar ainda outras duas ocorrências do gesto C, em diferentes configurações: uma primeira em c.18 (Fig. 19) e uma segunda, em c.21 (Fig. 20). Em c.18 o gesto $\mathrm{C}$ mantém diversas características comuns com a figura apresentada em c.12: rítmica regular, dinâmica em fortissimo (acompanhada pela indicação de violento) e uso do pedal de sustentação. Porém, em c.18, o gesto $\mathrm{C}$ apresenta perfil em ziguezague ao invés de perfil direcional, se diferenciando assim da figura apresentada em c.12:

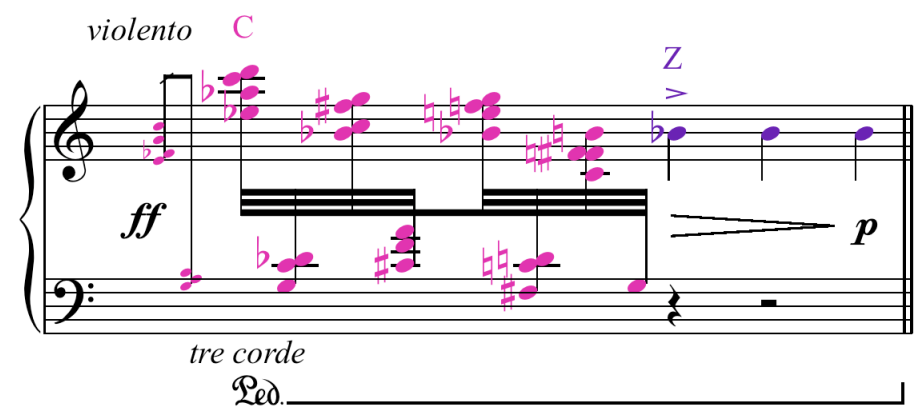

Fig. 19 - Gesto C em c.18.

Já a figura desenhada em c.21 (Fig. 20) incorpora as características de c.18 e realiza ainda algumas flexibilizações. Seu perfil é em ziguezague, a dinâmica se mantém em $f f$ (também acompanhada pela indicação violento) e há o uso do pedal de sustentação. Porém, em c.21, surgem ainda duas alterações com relação às figuras vistas em c.12 e c.18: há uma variação rítmica dentro do próprio gesto (mais precisamente um desacelerando escrito gerado 
pela passagem de um grupo de semifusas a um grupo de semicolcheias em quintina) e são incluídas algumas notas individuais dentro do fluxo de acordes, gerando uma espécie de polifonia entre uma linha mais melódica e outra mais acordal. O gesto C em c.21 incorpora características figurais tanto de c.18 (grupo de fusas) quando de c.12 (quintina de semicolcheias):

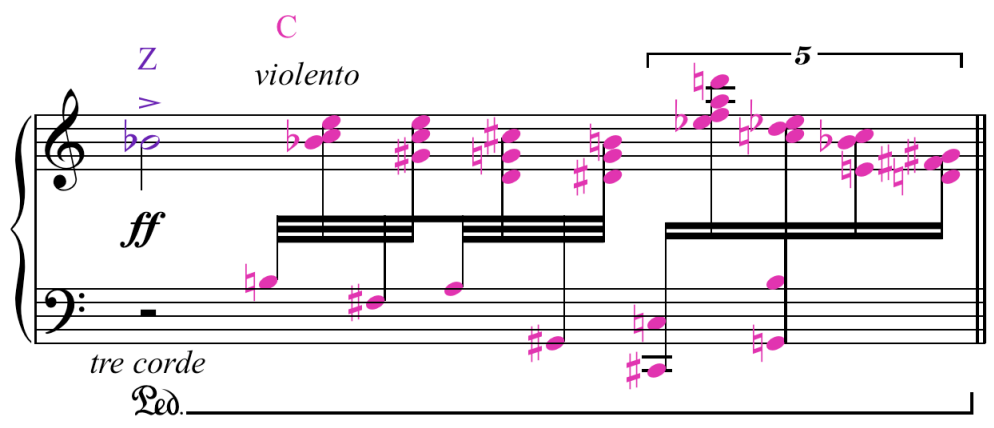

Fig. 20 - Gesto C em c.21.

Até o momento, além do gesto $\mathrm{Z}$, mapeamos outros três gestos (A, B, e C) com características distintas, porém todos com certa familiaridade entre si por se tratarem de aglomerados harmônicos. A partir de c.14, teremos a constituição de novos gestos, pertencentes a uma família mais melódica do que harmônica. Se até o momento mapeamos uma família de blocos, agora passaremos a considerar uma família de linhas. Também encontraremos um gesto com características similares ao gesto Z; juntos, eles passarão a compor uma família de pontos.

\section{Gesto D, E e F}

O primeiro gesto dentro desta nova família de linhas aparece no terceiro tempo de c.14. Este gesto, denominado D, caracteriza-se por uma linha horizontal, em movimento direcional, com ritmo constante e em alta velocidade (uso de fusas). 




Fig. 21 - Gesto D em c.14.

No final de c.15 e início de c.16 um segundo gesto ainda dentro dessa família de linhas é apresentado. Caracterizado por uma linha horizontal com ritmo constante e em alta velocidade (também em fusas), o gesto E se estabelece como um gesto semelhante ao gesto D, porém com uma diferença fundamental: seu perfil é ziguezagueante.



Fig. 22 - Gesto E em c. 15 e 16.

Um novo gesto bastante similar aos gestos D e E é apresentado um pouco mais adiante, em c.79. Esse gesto, denominado F, é similar aos gestos D e E por também apresentar ritmo constante e em alta velocidade (uso de fusas). Porém, diferentemente dos anteriores, o gesto F caracteriza-se pela repetição de uma mesma altura, destacando assim seu aspecto rítmico, percussivo. Nesse sentido, os gestos $\mathrm{Z}$ e F são complementares já que se concentram sobre a repetição contínua de durações longas (especialmente de semínimas) e de durações curtas (fusas), respectivamente. Os gestos $\mathrm{F}$ e $\mathrm{Z}$ integram uma família de pontos, e não 
exatamente de linhas, já que se caracterizam mais por um movimento rítmico do que melódico.

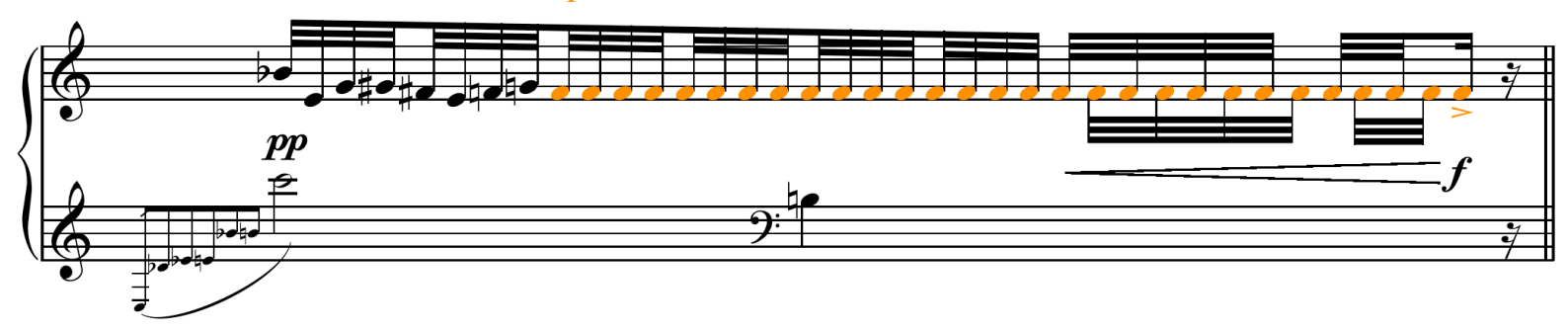

Fig. 23 - Gesto F em c.79.

Os gesto D, E e F são originários de Interlinea. Eles estão contidos de maneira condensada no compasso 13 dessa peça (correspondente a c.79 da Sonata), conforme ilustra a figura abaixo:



Fig. 24 - Origem dos Gestos D, E e F. Interlinea, c.13.

Na Sonata, Berio desmembra em três partes este que seria um gesto único em Interlinea. Diferentemente de Interlinea, encontraremos na Sonata trechos longos de aparição isolada de cada um desses três gestos, como é o caso do trecho compreendido entre c.76 e c.78, onde há a presença exclusiva do gesto E. Por isso, na Sonata, optamos por identificar cada um desses fragmentos - que se distinguem essencialmente pelo tipo de perfil que apresentam - como um gesto independente.

Os gestos D, E e F são recorrentes na escrita pianística de Berio, de maneira geral. A peça “Poinsts on a curve do find...", para piano e 22 instrumentistas, escrita em 1974, é 
inteiramente construída a partir de um gesto também caracterizado por um fluxo em movimento rápido e contínuo de fusas, às vezes congelado sobre duas notas (compressão da textura) e outras vezes desenvolvido sobre linhas direcionais (ampliação da textura). Dessa maneira, os gestos D, E e F da Sonata encontram fortes correspondências nos gestos apresentados em "Points on a curve do find...", especialmente os gestos D e E.

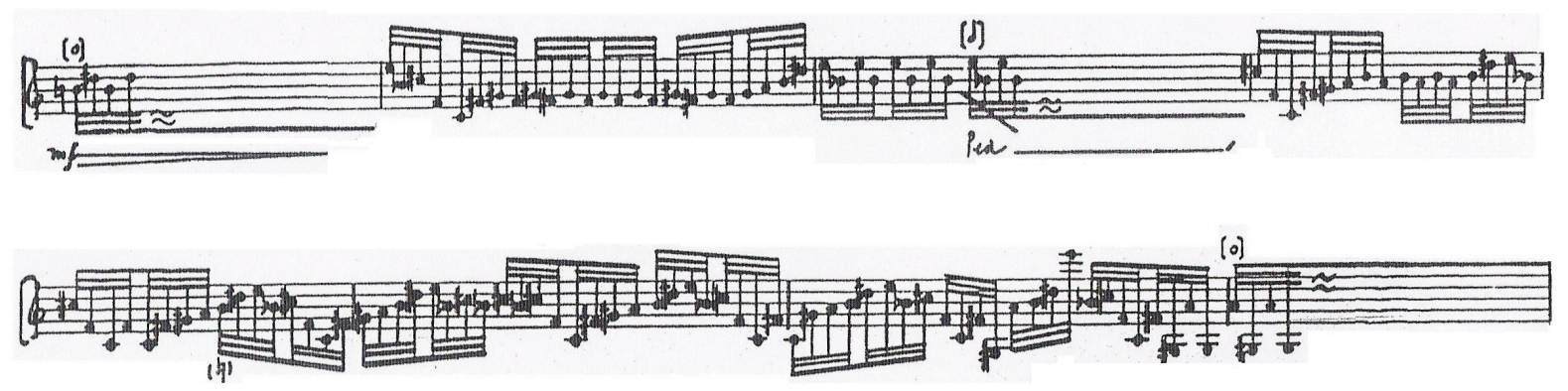

Fig. 25 - Gesto D em "Points on a curve do find...", c.28 a c.35 (somente piano).

Em Luftklavier, escrita em 1985 e publicada no conjunto de peças Six Encores (1990), também há uma forte presença de um gesto similar ao agrupamento formado por $\mathrm{D}, \mathrm{E}$ e F. Nessa peça, também encontramos um fluxo em movimento rápido e contínuo, novamente em fusas, que se desenrolam principalmente sobre movimentos melódicos em ziguezague ou sobre uma mesma nota repetida. Dessa maneira, em Luftklavier, a relação de proximidade gestual se dá mais especificamente com os gestos E e F da Sonata.
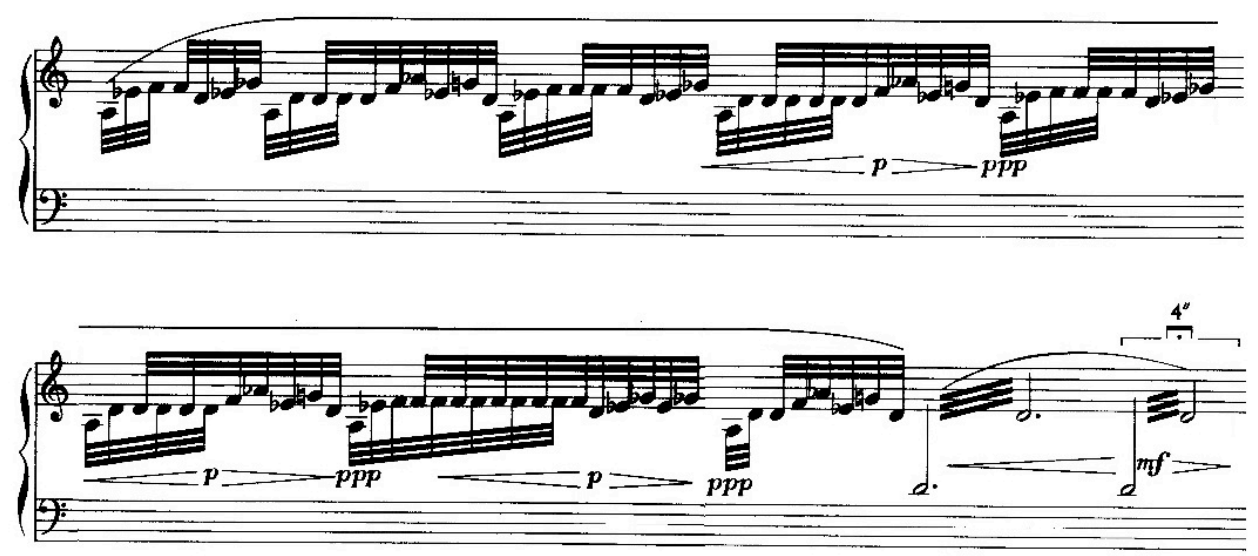

Fig. 26 - Gestos E e F em Luftklavier, (peça sem número de compasso). 


\section{$\underline{\text { Gesto G }}$}

Em c.26 podemos identificar ainda um último gesto presente na Sonata. Assim como os gestos D e E, o gesto $\mathrm{G}^{63}$ caracteriza-se por um movimento de linha horizontal. Porém, por possuir baixa velocidade, o gesto $G$ não se apresenta auditivamente como um fluxo sonoro mas sim como uma espécie de curva melódica, possibilitando a escuta de cada intervalo apresentado. Esse gesto possui tessitura ampla e tende a se desmembrar em diferentes registros, comportando saltos bastante grandes e criando assim um perfil acentuadamente anguloso. Sua construção melódica se comporta de maneira livre, sem delinear células melódico-motívicas ou temáticas recorrentes. O gesto G apresenta durações longas e regulares, em geral, em grupos de semínimas de tercina.

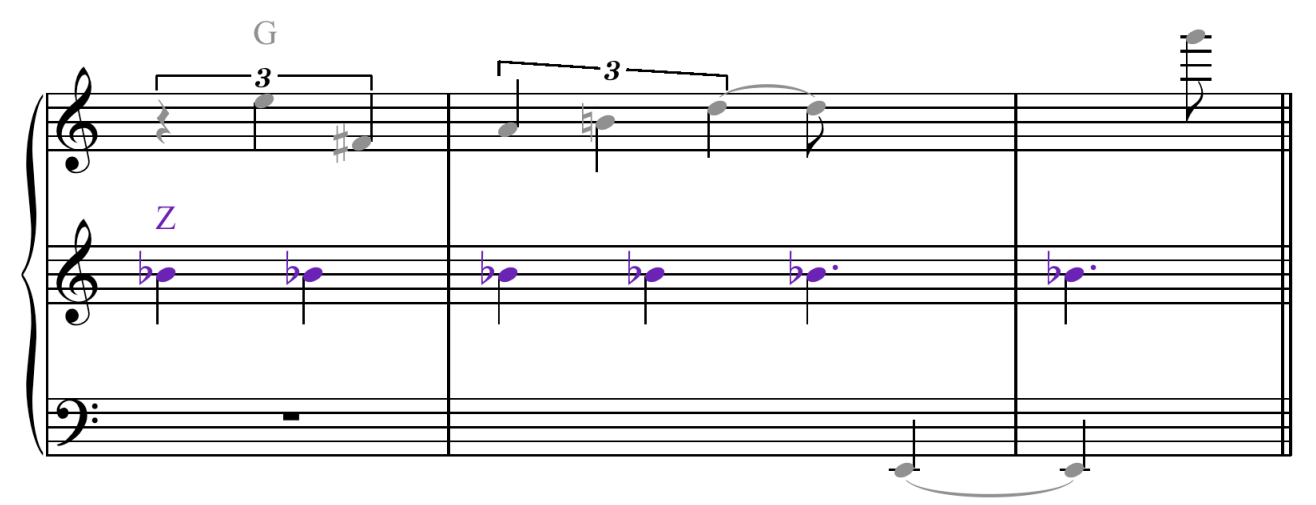

Fig. 27 - Gesto G em c.26, c.27 e c.28.

O gesto $\mathrm{G}$ é oriundo de Interlinea, mais especificamente dos seus sete primeiros compassos, onde uma espécie de linha melódica também aparece fragmentada por conta de sua distribuição em diferentes registros da tessitura (ver c.1 a c.7 de Interlinea na Fig. 09).

Após essa primeira análise, pudemos identificar um total de oito gestos relevantes

63. Apesar de esse gesto aparecer muitos compassos antes daquele que chamamos de F, optamos por inverter a nomenclatura de ambos no que diz respeito à ordenação alfabética para evidenciar a proximidade rítmica existente entre o gesto $\mathrm{F}$ e os gestos $\mathrm{D}$ e $\mathrm{E}$. 
dentro da Sonata, sendo seis deles originais de Interlinea. Somente os gestos Z e C são próprios à Sonata. O quadro abaixo sintetiza o conjunto de oito gestos constituídos no início da Sonata e comentados nesse capítulo. Os gestos foram agrupados em três famílias, uma formada por pontos (notas repetidas), outra formada por blocos (acordes) e uma última formada por linhas (movimentos melódicos). O quadro também apresenta de maneira sucinta as características gerais de cada gesto, além do número do compasso onde aparecem pela primeira vez. A letra "I" grafada entre parênteses indica os gestos que têm origem em Interlinea.

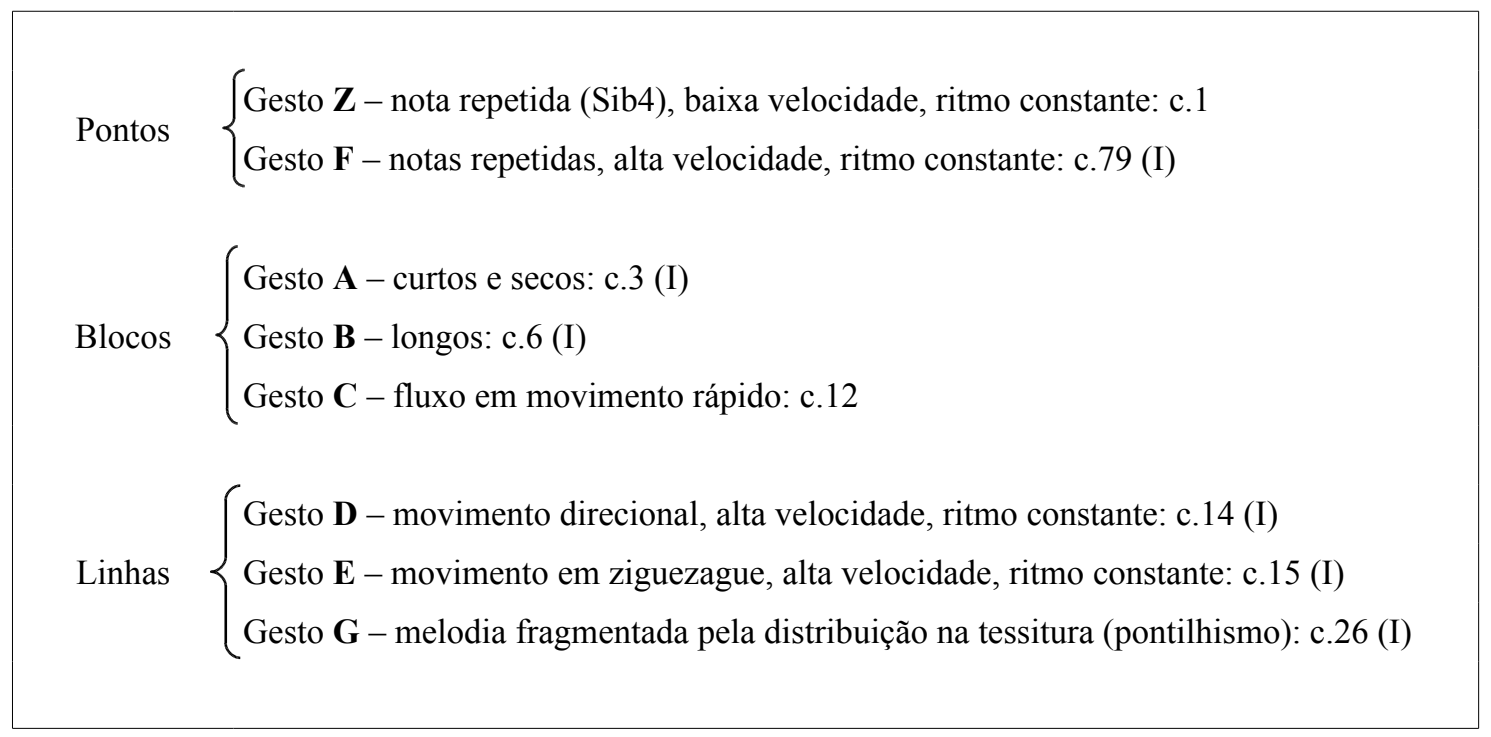

Fig. 28 - Síntese dos gestos mapeados no início da Sonata.

O agrupamento dos gestos em diferentes famílias foi orientado pelo aspecto textural de cada um deles, determinado, em grande medida, pela estruturação de seus parâmetros figurais. O parâmetro rítmico, por exemplo, pode ser observado evidentemente em todos os gestos da peça. Porém, alguns dos gestos são definidos especialmente por sua características rítmicas, isto é, se observados separadamente, eles imprimem uma escuta mais "percussiva" do que melódico-harmônica. Esse é o caso especificamente dos gestos Z e F que ao se concentrarem sobre notas repetidas colocam em evidência sua estrutura rítmica. Já os gestos A, B e C, caracterizam-se mais fortemente por uma textura verticalizada e por isso 
integram a família de blocos. E, finalmente, os gestos D, E e G se consolidam como gestos de textura mais horizontal, com maior tendência melódica, compondo assim uma família de linhas.

O mapeamento dos gestos iniciais presentes na Sonata possibilita realizar uma leitura que explicita o esquema de utilização desses gestos dentro da peça, verificando de que maneira eles são distribuídos e combinados dentro de cada compasso ${ }^{64}$. Apenas a critério de exemplo, a figura abaixo identifica passo-a-passo, nos 28 primeiros compassos da peça, a distribuição dos gestos já mapeados (com exceção do gesto F que só será apresentado a partir de c.79):

\begin{tabular}{|c|c|c|c|c|c|c|c|c|c|c|c|c|c|}
\hline c. 01 & c. 02 & c.03 & c.04 & c.05 & c.06 & c. 07 & c.08 & c. 09 & C. 10 & c. 11 & c. 12 & C. 13 & C. 14 \\
\hline \\
\hline & & & A & & B & A & \begin{tabular}{l|l|l}
$B$ & $A$ & $C$
\end{tabular} & & A & & C & B & D \\
\hline
\end{tabular}

\begin{tabular}{|l|c|c|c|c|c|c|c|c|c|c|c|c|c|}
\hline c.15 & c. 16 & c. 17 & c. 18 & c. 19 & c. 20 & c. 21 & c. 22 & c. 23 & c. 24 & c. 25 & c. 26 & c. 27 & c. 28 \\
\hline A & E & A & A & B & & C & B & B & & C & B & \multicolumn{1}{|c|}{ G } \\
\hline
\end{tabular}

Fig. 29 - Análise do esquema de distribuição dos gestos no início da Sonata, c.1 a c.28.

Uma análise como essa permitiria visualizar graficamente as diminuições e crescimentos de cada gesto, as tendências a agrupamentos, as sobreposições mais comuns etc. Na Fig. 29, por exemplo, é possível visualizar a diluição do gesto A e o crescimento dos gestos B e C. Também é possível perceber uma tendência a agrupamentos que se inicia com $\mathrm{A}+\mathrm{B}$, segue para $\mathrm{A}+\mathrm{C}$, passa por $\mathrm{A}+\mathrm{C}+\mathrm{B}$ e, finalmente, chega no agrupamento $\mathrm{C}+\mathrm{B}$, eliminando definitivamente o gesto A. Porém, apesar do interesse que possa haver nesse tipo de análise, um mapeamento gestual gráfico de toda a Sonata (como esse ilustrado pela Fig. 29) não integra o foco do nosso trabalho. Após o mapeamento realizado nesse capítulo, que identifica e caracteriza o comportamento de cada gesto que compõe a Sonata, verificaremos no Capítulo V como estes gestos dialogam entre si e de que maneira eles são associados à noção de processo. Antes de darmos continuidade ao comentário da noção de processo em

64. Um trabalho como esse foi realizado por Francis Courtot em sua análise do primeiro movimento do Quarteto de Cordas $n^{\circ} 3$ (1987) de Brian Ferneyhough, à qual chamou de análise morfológica. A análise de Courtot resulta numa tabela onde é possível verificar compasso-a-compasso quais os gestos utilizados em cada um dos quatro instrumentos. COURTOT, 2009, pp. 250-252. 
Berio, faremos um breve comentário no Capítulo IV a respeito da construção rítmica e harmônica dos gestos mapeados, propondo assim uma olhar mais aprofundado sobre suas características figurais mais gerais. 
capítulo IV - construção rítmica e harmônica 
De acordo com a caracterização dos gestos inicias da Sonata realizada no Capítulo III, podemos dividir o conjunto de gestos levantados em dois grandes grupos: um primeiro que reúne figuras de curta duração e um segundo que reúne figuras de maior duração. $\mathrm{O}$ quadro abaixo informa as figuras rítmicas mais comuns utilizadas em cada um dos gestos mapeados:

\begin{tabular}{|l|l|}
\hline \multicolumn{1}{|c|}{ Gestos com figuras de menor duração } & Gestos com figuras de maior duração \\
\hline $\begin{array}{l}\text { Gesto A: colcheias e semilcolcheias } \\
\text { (simples ou em tercina) em staccato. }\end{array}$ & $\begin{array}{l}\text { Gesto Z: valores iguais ou mais longos que } \\
\text { a semínima. }\end{array}$ \\
\hline $\begin{array}{l}\text { Gesto C: agrupamentos de semicolcheias } \\
\text { e fusas (muitas vezes em quiálteras } \\
\text { diversas). }\end{array}$ & $\begin{array}{l}\text { Gesto B: valores iguais ou mais longos } \\
\text { que a semínima (raramente colcheias, } \\
\text { porém combinadas com arpejo). }\end{array}$ \\
\hline $\begin{array}{l}\text { Gestos D, E e F: agrupamentos de fusas } \\
\text { (simples ou como subdivisões de tercinas } \\
\text { de colcheia), em geral em múltiplos de 4. }\end{array}$ & $\begin{array}{l}\text { Gesto G: tercina de semínimas, conferindo } \\
\text { característica ternária a esse gesto. }\end{array}$ \\
\hline
\end{tabular}

Fig. 30 - Características rítmicas dos gestos mapeados. 
Observando o comportamento rítmico dos gestos dentro da peça, podemos perceber que alguns deles apresentam estruturas rítmicas regulares, isto é, restritas a uma determinada figura que tende a se consolidar como uma espécie de identidade rítmica própria ao gesto. Esse é o caso dos gestos D, E e F (Fig. 21, Fig. 22 e Fig. 23), que contam sempre com a figura de fusa, por vezes inserida como subdivisão de uma tercina de colcheia. Os gestos Z e G (Fig. 12 e Fig. 27) também apresentam regularidade rítmica, porém contam com figuras mais longas que as dos gestos D, E e F. O gesto Z concentra-se sobre a figura de semínima, passando em alguns momentos sobre outras figuras, especialmente as de colcheia, semínima pontuada ou mínima. Já o gesto G aparece, na maior parte das vezes, com um ritmo ternário, sendo grafado sobre figuras de tercina de semínima.

Por sua vez, os gestos A, B e C (Fig. 14, Fig. 17 e Fig. 18), ao contrário dos demais, não apresentam regularidade rítmica, mas sim um tipo de comportamento temporal que se restringe a figuras de curta ou longa duração. Dessa maneira, os gestos A e C se caracterizam por figuras de curta duração enquanto o gesto B se caracteriza por figuras de duração maior. Porém, essas figuras são bastante variadas. O gesto A, por exemplo, aparece na maior parte das vezes em colcheia ou semicolcheia (simples ou em tercina) acompanhada de uma indicação de staccato, porém sua localização métrica é variada. O gesto $\mathrm{B}$ se desenrola sobre figuras de maior duração, em oposição ao gesto A, podendo aparecer sobre semínimas, semínimas pontuadas, mínimas etc. O gesto $\mathrm{C}$ tende a aparecer sobre figuras de semicolcheia e fusas, porém seus agrupamentos também variam, aparecendo por vezes como um conjunto de oito fusas, outras vezes como uma quintina de semicolcheias, e assim por diante. Os dois exemplos a seguir apresentam os gestos de rítmica regular (com suas figuras características) e os gestos de rítmica irregular (com suas figuras mais comuns):

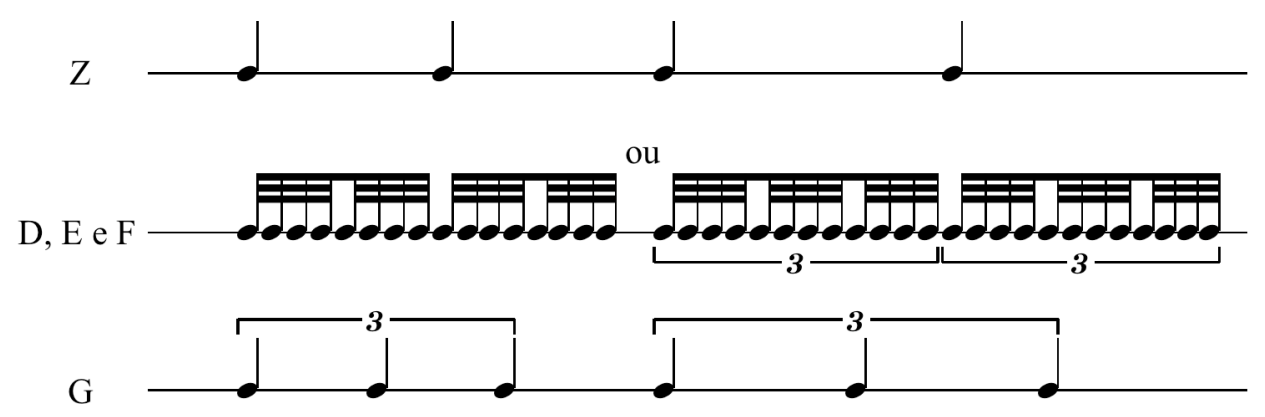

Fig. 31 - Gestos com figuras rítmicas regulares: Z, D, E, F e G. 




Fig. 32 - Gestos com figuras rítmicas variadas: A, B e C.

Apesar de os gestos Z, D, E, F e G apresentarem figuras rítmicas regulares, eles comportam certos deslocamentos. Os gestos Z e G, por exemplo, são deformados especialmente através da modificação da pulsação. Na Sonata são utilizadas três fórmulas de compasso que se alternam: 4/4,5/4 e 7/8. A inserção de um compasso 7/8 agrega à estrutura rítmica da Sonata quebras sutis na regularidade do pulso em semínimas, provocando breves deslocamentos que modelam principalmente os gestos de maior regularidade rítmica e com durações mais longas, isto é, os gestos Z e G. No início da Sonata, por exemplo, em c.14 ou em c.22-23, o compasso 7/8 comporta uma oscilação na estrutura rítmica do gesto $\mathrm{Z}$ que, em meio a repetições de semínimas, agrega o valor de semínima pontuada:



Fig. 33 - Gesto Z com alterações rítmicas: uso do compasso 7/8, em c.22-23.

Entre c.26 e c.28 (Fig. 27) podemos observar um exemplo ainda mais completo de oscilação provocada nos gestos $Z$ e $G$, simultaneamente. Nesse trecho, a inserção de um compasso $7 / 8$ permite a alteração da figura de semínima do gesto $Z$ (sua figura característica) para uma figura de semínima pontuada, além de uma quebra no grupo de semínimas de 
tercina do gesto G (sua figura característica), possibilitando um desacelerando escrito.

Diferentemente dos gestos $\mathrm{Z}$ e G, os gestos D, E e F são deformados através da sobreposição de ciclos de tamanhos variados. Um bom exemplo desse tipo de procedimento pode ser verificado no gesto E, entre c.153 a c.155. Nesse trecho, o gesto E aparece grafado em tercinas de semicolcheia para compensar a alteração do andamento que passa a $104 \mathrm{bpm}$. Apesar de grafado com uma nova figura, o gesto E se mantém praticamente na mesma velocidade do que aquela apresentada nos primeiros compassos da Sonata. A deformação que ocorre nesse trecho não é, portanto, relativa à estrutura rítmica do gesto E mas sim à maneira como ele reúne ciclos de diferentes tamanhos. Sobre um contínuo rítmico em tercinas de semicolcheias (há apenas uma exceção no fim de c.153, quando ocorre uma quintina de semicolcheias) são sobrepostos dois ciclos: um primeiro, marcado pela repetição de duas alturas (notas rebatidas); e um segundo, caracterizado por uma movimentação melódica livre que caminha em direção a outras duas notas que serão novamente estabilizadas por repetição. As figuras a seguir apresentam o trecho original em questão e seu desmembramento em dois ciclos, respectivamente. As marcações na cor laranja delimitam o ciclo caracterizado pelas notas rebatidas e as marcações na cor marrom indicam os grupos de notas que compõem o ciclo caracterizados pela movimentação melódica livre. Nas duas representações é possível perceber que, inicialmente, os dois ciclos melódicos aparecem bastante deslocados com relação à métrica prevista pelo ostinato de tercinas de semicolchieas até que, no terceiro tempo de c.155, os ciclos melódicos entram em fase com a estrutura rítmica de tercinas, se alternando em grupos de três ou seis notas: 

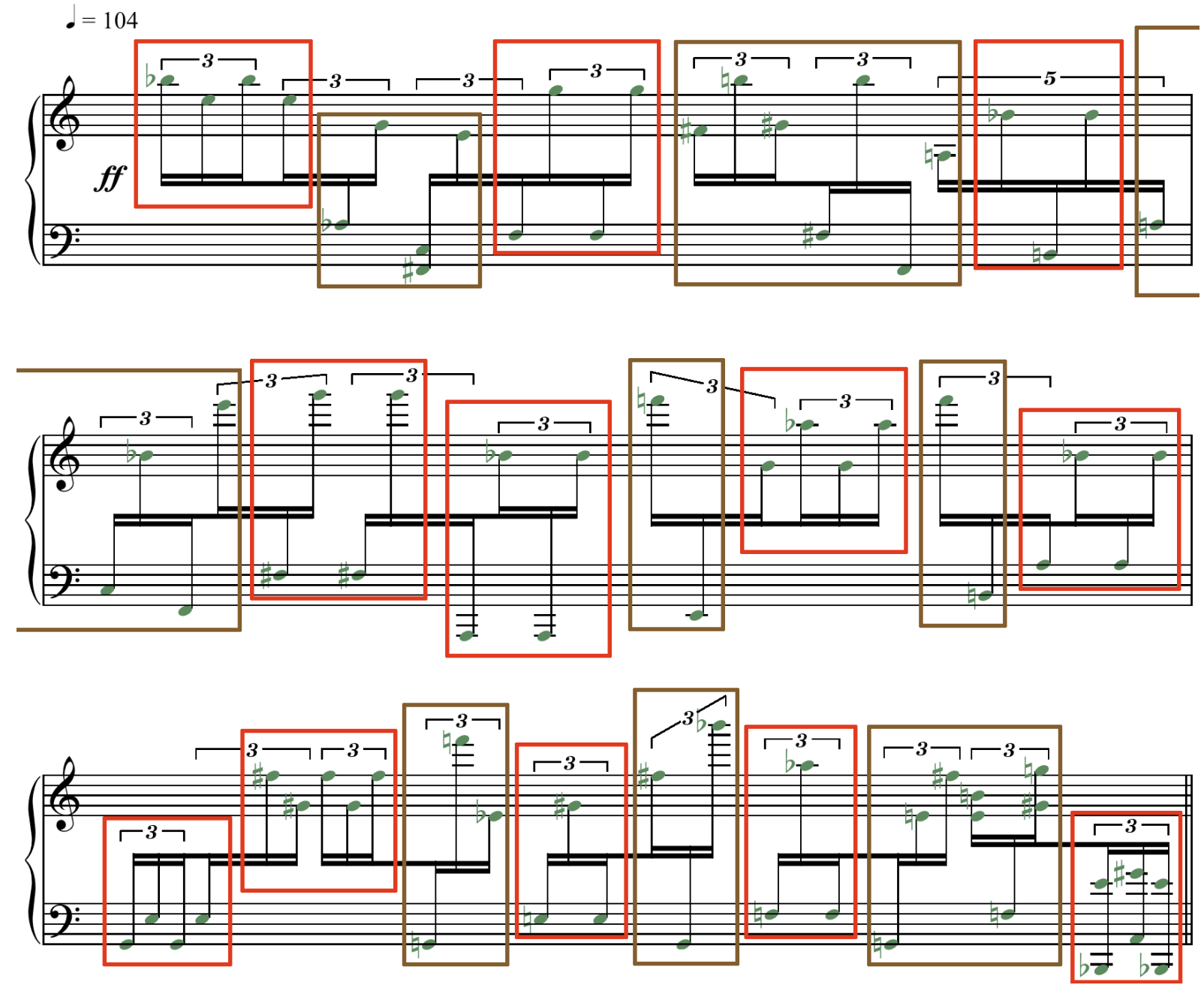

Fig. 34 - Gesto E: sobreposição de dois ciclos melódicos, em c.153 a c.155: com notas rebatidas (laranja) e com movimentação livre (marrom). 

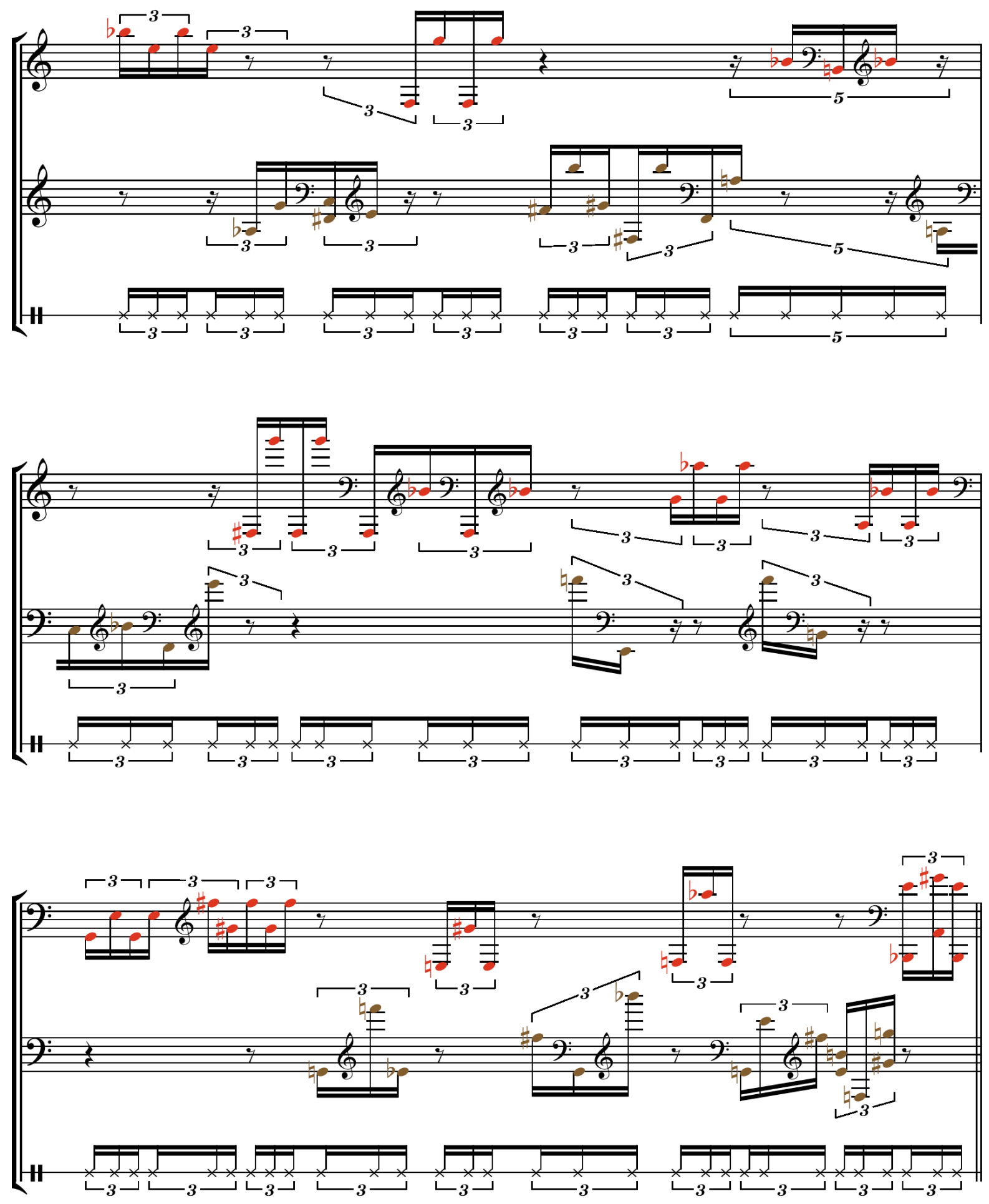

Fig. 35 - Gesto E: sobreposição de dois ciclos melódicos, em c.153 a c.155: com notas rebatidas (laranja) e com movimentação livre (marrom). 
Há, portanto, a simulação de uma polifonia rítmica que se contrapõe ao ostinato de tercinas de semicolcheia, proporcionando certa irregularidade dentro de uma rítmica regular. Deslocamentos rítmicos como esses, exemplificados na Fig. 33, Fig. 34 e Fig. 35, proporcionam aos gestos Z, G, D, E e F - a princípio caracterizados por uma acentuada regularidade rítmica - maior soltura e mobilidade dentro da peça. Apesar disso, a seleção de um número limitado de figuras rítmicas para cada um dos gestos (sejam eles mais ou menos regulares) contribui para a construção de figuras quase autônomas dentro da peça. Cada um dos gestos pode ser reconhecido por seu comportamento rítmico que, mesmo com certas deformações, tende a se concentrar sobre um conjunto bastante restrito de figuras rítmicas. Novamente, há uma tensão entre a idéia de fechamento e abertura que tem cercado nossos comentários desde o início do trabalho.

Para concluir essa leitura sintética acerca da construção rítmica da Sonata, é importante ainda mencionar uma característica que perpassa a estrutura rítmica de todos os gestos: independente de sua regularidade ou irregularidade rítmica, os oito gestos são circunscritos a subdivisões de um pulso regular que se concentra, em geral, sobre uma figura de semínima. As quebras de pulso geradas pela inserção de um compasso 7/8, como vimos na Fig. 33, deformam os gestos $\mathrm{Z}$ e $\mathrm{G}$ mas não chegam a concretizar uma instabilidade global do pulso dentro da peça. Assim, pelo fato de estarem circunscritos a subdivisões de um pulso regular - ainda que eventualmente oscile entre semínimas (4/4 e 5/4) e colcheias (7/8) - os gestos apresentam o predomínio de um tempo estriado ${ }^{65}$ dentro da Sonata. De maneira geral, o tempo estriado é característico da escrita de Berio. A estruturação rítmica de suas peças ainda que contem com certas flexibilizações resultantes do uso de quiálteras e ritmos mais irregulares, ou mesmo de certas variações de compasso - se conforma, em geral, à noção de um pulso regular.




IVb. harmonia

Em seu livro Luciano Berio et la Phonologie, publicado em 1993, Flo Menezes aponta certas constantes harmônicas na escrita de Berio partindo de um olhar sobre as oito primeiras Sequenze, escritas ao longo de quase 20 anos, de 1958 a 1976. Flo Menezes inicia seu comentário dizendo que essas oito Sequenze teriam uma característica em comum: "a oposição binária entre o elemento estático (ou o elemento-pivô) e os processos evolutivos da forma. Dito de outra maneira, a oposição entre dois aspectos da harmonia: um não-direcional; outro, direcional” (MENEZES, 1993, p.187) ${ }^{66}$. Em seguida, Flo Menezes identifica aspectos direcionais (elementos constituídos progressivamente) e não-direcionais (estacionários, elementos-pivô) em cada uma das oito Sequenze, expondo, assim, uma dualidade harmônica que, segundo ele, se consolidaria como um traço estilístico desse ciclo de peças. Na Sequenza VIII, para violino, por exemplo, as notas $\mathrm{A} \sharp$ e $\mathrm{B}$ q (e o intervalo de segunda maior resultante), atacadas harmonicamente durante toda a peça, seriam aspectos não-direcionais. Em oposição a esse aspecto estacionário, estaria a utilização do total cromático que é apresentado de maneira gradativa e que se consolida assim como um

66. "L'opposition binaire entre l'élément statique (ou l'élément-pivot) et les processus évolutifs de fa forme. Il s'agit autrement dit, de l'opposition entre deux aspects de l'harmonie: l'un non-directionnel; l'autre, directionnel". 
elemento direcional.

A partir dessa dualidade harmônica verificada nas oito primeiras Sequenze, Flo Menezes estende seu comentário a uma grande variedade de peças e sintetiza o que chamou de três princípios harmônicos típicos da escrita de Berio: "a oposição binária entre o uníssono e os aglomerados cromáticos complexos; a complementaridade cromática; a onipresença do intervalo de terça" (MENEZES, 1993, p. 189) ${ }^{67}$. Apesar de a Sonata ter sido escrita alguns anos após o conjunto de peças analisadas por Flo Menezes, esses três princípios harmônicos ainda operam nela com bastante força. De fato, Interlinea pode ser compreendida integralmente com base nesses três princípios, porém veremos que na Sonata também são agregadas outras características harmônicas, próprias ao universo sonoro dessa peça.

O primeiro princípio apontado por Flo Menezes, de uma oposição binária entre o uníssono e os aglomerados harmônicos complexos é exemplificado em trechos de diversas peças de Berio. Em um fragmento de Laborintus II, Flo Menezes (1992, p. 197) mostra como o conjunto instrumental parte de um uníssono sobre a nota $\mathrm{A}$ b e, após movimentações de cada uma das vozes, atinge um conglomerado harmônico formado pelas doze notas. A oposição entre uníssono e aglomerados harmônicos é quase o grande tema inicial da Sonata. Como vimos no Capítulo III, o gesto Z, caracterizado pela repetição de uma única nota, sempre num mesmo registro, se consolida como uma camada independente que é confrontada inicialmente por alguns conjuntos verticais, isto é, pelos gestos A, B e C. Num segundo momento, o gesto $\mathrm{Z}$ passa a se confrontar com gestos mais melódicos, isto é, com os gestos $\mathrm{D}$, E e G que, apesar de não se tratarem de conjuntos vesticais, também se opõem ao uníssono característico do gesto $\mathrm{Z}$ por se estruturarem, em geral, sobre conjuntos de mais de seis sons. Mais adiante, após a diluição do gesto $Z$, quem assumirá o papel de mantenedor de uma camada formada pela repetição de um único som, isto é, uma camada de aspecto estacionário e não-direcional, será o gesto $\mathrm{F}$, que sustentará a oposição entre uníssonos e aglomerados harmônicos até o fim da peça.

O segundo princípio apontado por Flo Menezes, da complementaridade cromática, também está presente na Sonata. Esse princípio pode ser bem ilustrado na Sequenza VIII, para violino, onde as alturas são inseridas paulatinamente até que o total cromático seja atingido. Nessa peça, num primeiro momento, como deformações do conjunto formado pelas notas $\mathrm{A}$ ‡ e $\mathrm{B} \sharp$, são inseridas harmonicamente outras sete notas, que aparecem

67. "L'opposition binaire entre l'unisson et des agglomérats chromatiques complexes; la complémentarité chromatique'; l'omniprésence de l'intervalle de tierce". 
na seguinte ordem: $G \sharp, B, G \sharp, C \sharp, D \sharp, C \sharp, F$. Num segundo momento, são inseridas as outras três notas restantes $-\mathrm{D} \sharp, \mathrm{F} \sharp \mathrm{e} \mathrm{E} \sharp$ - através de movimentos melódicos rápidos que passam a ser intercalados com o gesto inicial. Dessa maneira, a Sequenza VIII estaria inteiramente construída sobre essa dualidade harmônica entre um aspecto não-direcional (conjunto $A q+B \sharp$ ) e um aspecto direcional (conjunto cromático), sendo que o aspecto direcional é construído através de uma idéia de complementaridade cromática. Na Sonata, o princípio da complementaridade cromática também está presente. Ele pode ser observado já nos compassos iniciais da peça. Tomemos como exemplo os seis primeiros acordes apresentados pelo gesto A entre c. 3 e c.6:

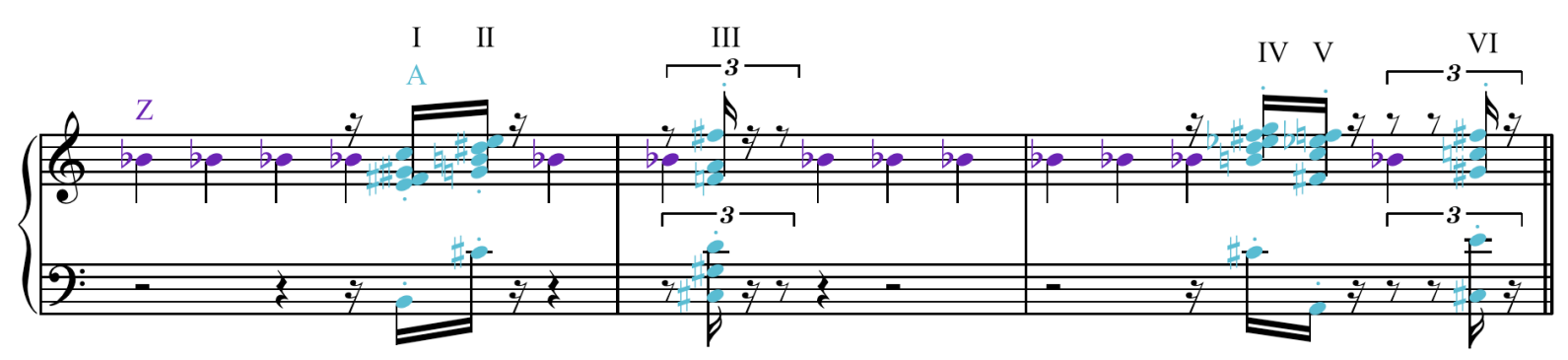

Fig. 36 - Gesto A, c.3 a c.5.

A figura a seguir mostra de maneira esquemática as alturas que compõe cada um desses acordes. Através dessa representação é possível perceber que um acorde sempre complementa o acorde anterior, expandindo gradualmente a quantidade de notas utilizadas do total cromático. Esses seis acordes são divididos em duas "frases" de três acordes cada. Em cada uma dessas frases, são apresentadas onze notas do total cromático. A única nota não incluída no conjunto dos acordes é o B , que aparece articulado simultaneamente pelo gesto $\mathrm{Z}$. Esse procedimento de complementaridade cromática é similar àquele comentado na Sequenza VIII. Porém, na Sonata, a passagem de um acorde a outro agrega um segundo princípio, o da manutenção de notas comuns entre diferentes acordes. Esse recurso contrabalança com a complementaridade cromática na medida em que garante a permanência de um conjunto de notas comuns enquanto novas alturas são introduzidas. A combinação desses dois princípios complementaridade cromática e manutenção de notas comuns - está presente nas passagens de um acorde a outro ao longo de toda a peça. 


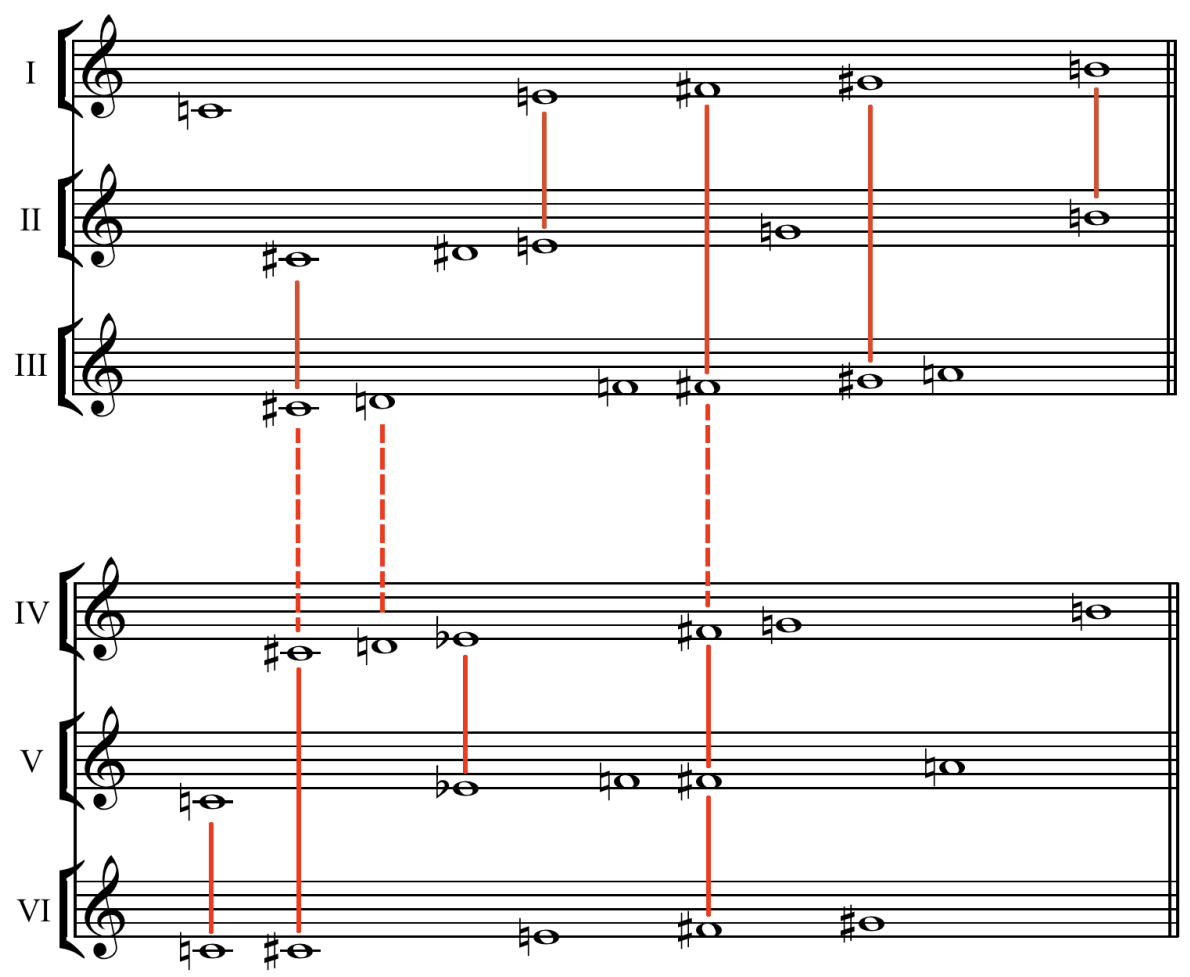

Fig. 37 - Complementaridade cromática e manutenção de notas comuns nos seis primeiros acordes da Sonata, c. 3 a c.5.

Esse segundo princípio da complementaridade cromática também pode ser observado no âmbito da história energética de um único gesto. É possível verificar essa tendência à utilização dos doze sons através da observação das aparições iniciais do gesto $\mathrm{E}$, por exemplo. Em sua primeira aparição, em c.15, o gesto E apresenta um figura composta por oito notas diferentes. Em suas seis aparições subseqüentes (c.16, c.31, c.39, c,40, c.45 e c.54), o gesto E oscilará sempre entre sete e oito sons. Em c.55, a figura já é composta por nove notas diferentes por conta da incorporação da nota $\mathrm{B}$, dentro de sua estrutura rítmica. Em c.72, a figura incorpora onze notas diferentes e, finalmente, em c.76-77, a figura passa pelas doze notas do total cromático. 


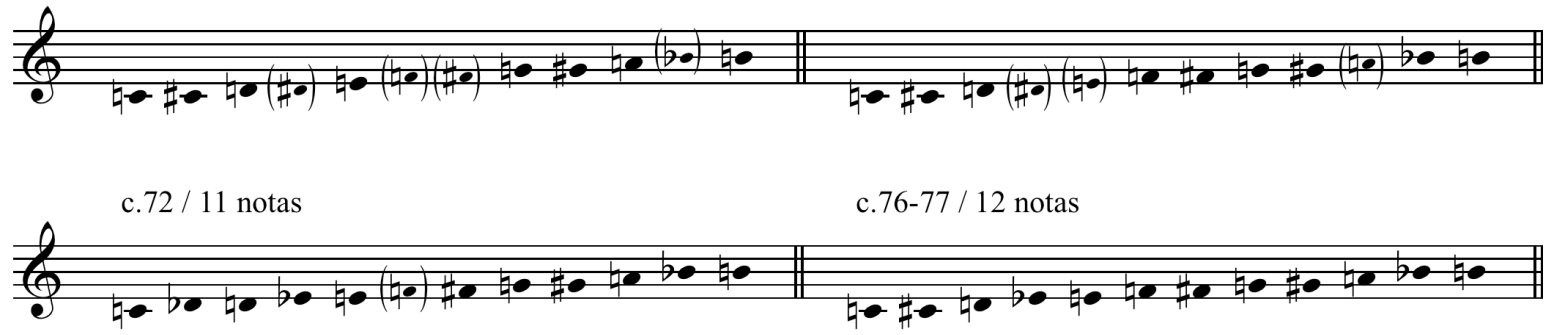

Fig. 38 - Conjunto de alturas que compõem o gesto E em c. 15, c.40, c.55 e c.76.

O terceiro e último princípio harmônico identificado por Flo Menezes se refere à ampla utilização do intervalo de terça nas peças de Berio. Em seu livro, Flo Menezes comenta a onipresença do intervalo de terça (em especial de terça menor) em peças de grande extensão, como Laborintus II (1965), Sinfonia (1968/69), "Points on a curve to find... (1974)" e Coro (1974/75), demonstrando que tal princípio é efetivamente um importante fator de organização harmônica na escrita de Berio. É importante evidenciar que os exemplos apontados por Flo Menezes cobrem um período de quase trinta anos, entre 1951 e 1980. Flo Menezes observa que mesmo em Nones (1954), composta ainda dentro de um universo permeado pelo serialismo integral, o intervalo de terça é elemento estruturador da série utilizada na peça ${ }^{68}$. Com a ênfase na utilização dos intervalos de terça já a partir dos anos 50 (ainda que tal característica ganhe maior relevância nos anos 60), Berio constrói um universo harmônico próprio em meio às tendências pós-tonais sem, no entanto, recair num universo tonal. É relevante observar como Berio não prioriza formações acordais que enfatizem a sobreposição de $2 \mathrm{~m}$ ou de $3 \mathrm{~m}$ em seqüência direta, evitando assim o uso excessivo de trítonos, sétimas e nonas menores, e fugindo de uma sonoridade cromática. Ainda que Berio estivesse inserido num contexto de reflexão e produção musical que corria na esteira do serialismo (cursos de Darmstadt, anos 50), sua escrita opera uma revalorização da expressividade do intervalo de terça, tratado de certa forma como um tabu no pensamento serial:

Como qualquer outro compositor de sua geração, ele foi obrigado a encontrar seu próprio caminho através das ironias da harmonia pós-tonal

68. Comentaremos a peça Nones com maior detalhe no Capítulo V. A formação de conjuntos de terça maior e menor na série de Nones pode ser verificada na Fig. 51. 
[...]. A solução de Berio foi em parte uma reação à concepção restrita de harmonias baseadas em sétimas e nonas a partir da qual os experimentos do pensamento musical dos anos 50 haviam sido realizados. Ele começou a explorar cada vez mais esse setor extraordinariamente rico do novo espectro harmônico no qual encadeamentos de terça (e algumas vezes de quartas) oferecem ao ouvido um caminho dentro de uma formação harmônica complexa (OSMOND-SMITH, 1991, p.36) ${ }^{69}$.

$\mathrm{Na}$ Sonata, a presença do intervalo de terça pode ser notada especialmente na formação das estruturas acordais. A figura a seguir mostra alguns exemplos de acordes construídos a partir da sobreposição de terças, em geral levemente desfocados pela incorporação de intervalos de $2 \mathrm{~m}$, criando algumas tensões dentro de acordes de acentuada consonância. Os dois primeiros aglomerados exemplificados integram uma mesma família de acordes. A estrutura harmônica formada pela sobreposição de dois intervalos de terça e pela incorporação de um intervalo de $2 \mathrm{~m}$, criando um pequeno atrito com algumas das outras três notas, é amplamente utilizada na Sonata. O terceiro acorde já apresenta uma estrutura harmônica mais complexa, com um aglomerado composto por nove notas diferentes, porém ainda evidenciando a sobreposição de terças:

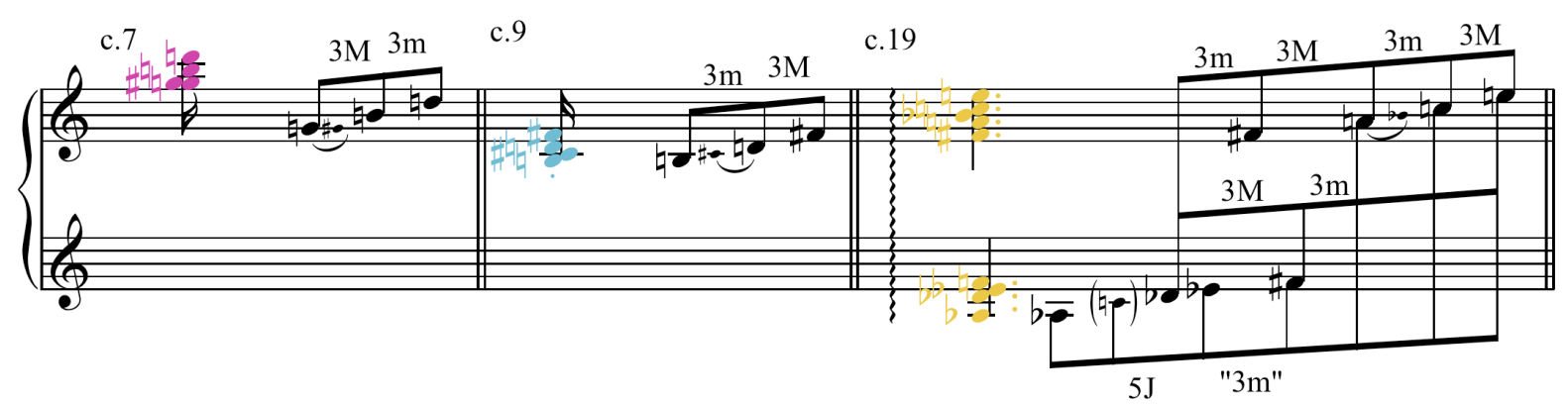

Fig. 39 - Modelo I: acordes com estrutura em 3m e 3M nos gestos C, A e B, respectivamente.

Também é possível verificar uma ampla proliferação do intervalo de terça no que se refere à disposição de eixos harmônicos dentro da peça. O gesto $\mathrm{F}$, por exemplo, que assume o papel de eixo harmônico após a diluição do gesto Z, realiza um percurso que coloca em evidência as seqüências de terças. Ao contrário do gesto $Z$, que se concentrava sobre uma

69. "Like any other composer of his generation, he was compelled to find his own path through the ironies of post-tonal harmony [...]. Berio's solution was in part a reaction to the rather narrow range of seventh-and ninthbased harmonies within which the experiments in musical thought of the fifties had been carried out. He increasingly began to explore that extraordinary rich sector of the new harmonic spectrum in which chains of thirds (and sometimes fourths) provide do ear with stepping-stones into a complex harmonic formation”. 
única nota $(\mathrm{B}, 4)$, o gesto $\mathrm{F}$ é bastante móvel e se desloca por diferentes eixos harmônicos. Esse movimento, em geral, tende a priorizar saltos de $3 \mathrm{~m}$ e $3 \mathrm{M}$. A figura a seguir mostra o percurso global do gesto F, que pode ser dividido em três grandes momentos: de c.79 a c.146; de c.188 a c.194; e de c.266 a c.335. Nesse exemplo, é possível perceber a preferência por movimentações através de saltos de terças:



c. 188 a c. 194

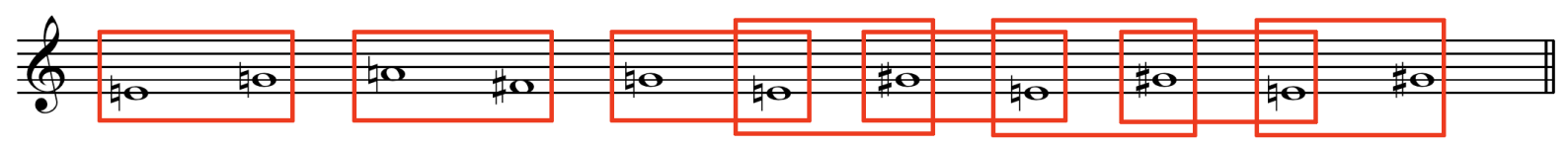

c. 286 a c. 335



Fig. 40 - Proliferação de terças através do gesto F.

Além do modelo de construção de acordes por sobreposição de terças, a Sonata apresenta também outros dois modelos, a partir da sobreposição de diferentes intervalos. Algo dessa expansão harmônica já havia sido comentada no Capítulo II, quando tratávamos de comparar os trechos originais de Interlinea com seus respectivos trechos reescritos dentro da Sonata. Naquele contexto vimos, por exemplo, como a Sonata operava uma expansão harmônica do material inicial de Interlinea agregando às formações compostas especialmente por intervalos de terça menor (característicos de Interlinea) os intervalos de 2M (Fig. 4). Sob essa perspectiva, é possível dizer que Interlinea é exemplar no que diz respeito ao terceiro princípio harmônico identificado por Flo Menezes e que a Sonata opera uma expansão harmônica dessa peça, promovendo um adensamento através da incorporação de outros intervalos característicos. Na Sonata são combinados ao modelo de acorde por sobreposição de $3 \mathrm{~m}$ e $3 \mathrm{M}$ - cuja sonoridade é mais diatônica - os acordes formados por sobreposição de $2 \mathrm{M}$ e $3 \mathrm{M}$ - que resultam numa sonoridade hexafônica - e os acordes formados por 
sobreposição de quartas, que conferem uma sonoridade harmônica própria a essa peça. As duas figuras a seguir apresentam alguns exemplos desses dois outros modelos de formação acordal presentes na Sonata:
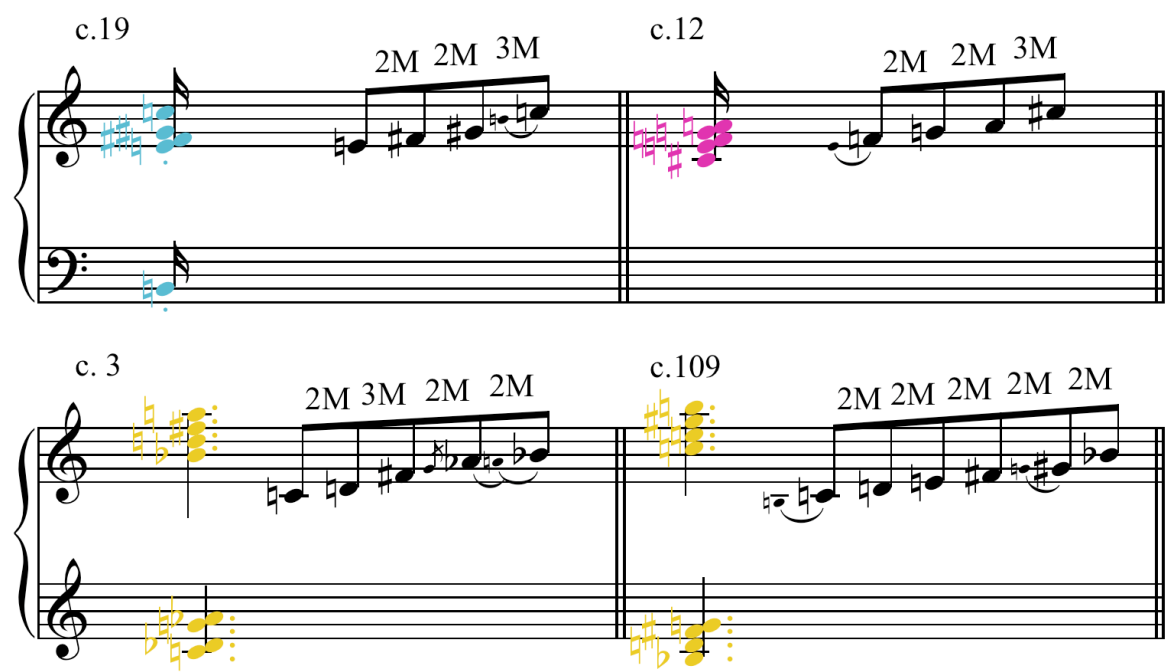

Fig. 41 - Modelo II: acordes com estrutura em 2M e 3M (tons inteiros) nos gestos $\mathrm{A}, \mathrm{C}$ e $\mathrm{B}$, respectivamente.

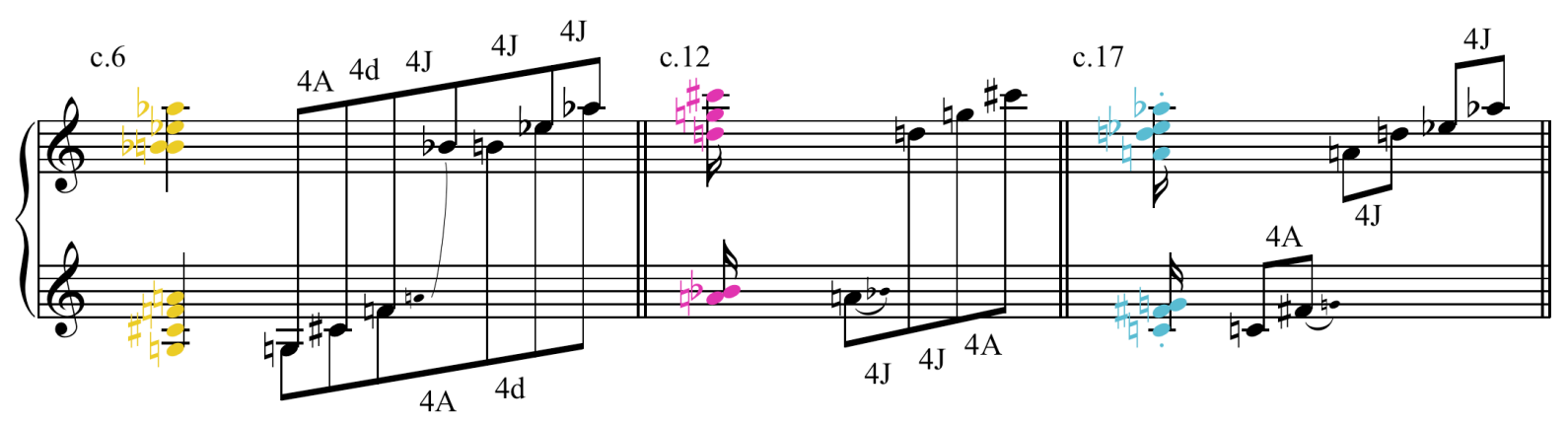

Fig. 42 - Modelo III: acordes com estrutura em quartas nos gestos B, C e A, respectivamente.

Nas três figuras dedicadas aos modelos de acordes presentes na Sonata (Fig. 39, Fig. 41 e Fig. 42), foram selecionados, propositadamente, exemplos que incluíssem os gestos A, B e C, ou seja, os três gestos que são caracterizados justamente por blocos harmônicos verticais. A intenção é demonstrar que os três gestos apresentam os três modelos de acorde. Assim, o gesto A aparece tanto com acordes por sobreposição de $3 \mathrm{~m}$ e $3 \mathrm{M}$, quanto por 
sobreposição de $2 \mathrm{M}$ e $3 \mathrm{M}$ e por sobreposição de quartas. $\mathrm{O}$ mesmo ocorre com os gestos $\mathrm{B}$ e C. Isso significa dizer que na Sonata o discurso harmônico se estrutura de maneira independente do discurso gestual, e vice-versa. Ao contrário do que observamos no tópico sobre o ritmo, os gestos não possuem uma identidade harmônica fixa. O plano harmônico parece ser justamente o responsável por um alto grau de intercâmbio entre os diferentes gestos. A critério de exemplo, a Fig. 43 apresenta a primeira aparição do gesto C, em c.12, num fluxo de cinco acordes consecutivos. Observando o gesto com maior detalhe, é possível perceber que ele reúne num só evento os três modelos de acordes anteriormente verificados:

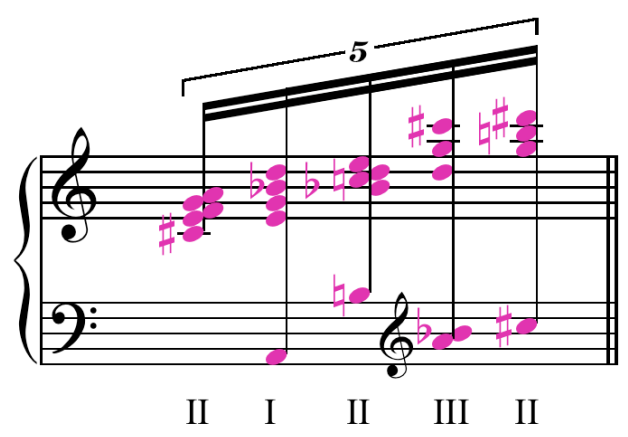

Fig. 43 - Modelos I, II e III agrupados no gesto C, em c.12.

Há ainda um último procedimento harmônico utilizado na Sonata e também característico da escrita de Berio a ser comentado: a criação de centros harmônicos provisórios através do congelamento de notas ou acordes num determinado registro. No início da peça, por exemplo, um acorde de oito notas $[\mathrm{G} \sharp, \mathrm{C} \sharp, \mathrm{F} \sharp, \mathrm{A} \sharp, \mathrm{B}, \mathrm{B}, \mathrm{B}, \mathrm{E} b, \mathrm{~A} b]$ é apresentado no quarto tempo de c.6. Esse mesmo acorde é repetido sem alterações no primeiro tempo de c.8 e, novamente, no primeiro tempo de c.13. Simultaneamente, um segundo acorde formado por quatro notas $[G \sharp, G \sharp, B \sharp, D \sharp]$ também aparece como uma estrutura reincidente. Sendo apresentado pela primeira vez no quarto tempo de c.7, ele volta a aparecer outras três vezes em c.8 e, novamente, em c.10. Um terceiro acorde formado por quatro notas $[\mathrm{C} \sharp, \mathrm{F} \sharp, \mathrm{F} \sharp, \mathrm{B} \sharp]$ é apresentado no primeiro tempo de c.10. Ele aparece novamente sem modificações no segundo tempo de c.15 e no primeiro tempo de c.18. Esse procedimento de criação de centros harmônicos provisórios através do congelamento de uma nota ou de um aglomerado harmônico é repetido durante toda a peça. Um determinado acorde é apresentado e ecoa pelos compassos seguintes. Enquanto ele ecoa, um novo acorde será apresentado e desempenhará o mesmo papel. Há, portanto, uma espécie de "entelhamento" entre eixos harmônicos 
subseqüentes.

É muito comum identificarmos algumas estruturas harmônicas reincidentes em diferentes pontos da Sonata, às vezes até bastante afastados. O acorde apresentado em c.35 $[\mathrm{B} \sharp, \mathrm{C} \sharp, \mathrm{E} b, \mathrm{~F} \sharp, \mathrm{G} \sharp]$, por exemplo, é articulado uma segunda vez em c.38. Mantendo-se um longo tempo oculto, ele volta a se estruturar gradativamente a partir de c.66, aparecendo novamente completo em c.70 e em c.75. Esse mesmo acorde é reutilizado na Sonata em momento posterior, a partir de c.109, sendo articulado ainda outras três vezes, em c.110, c.111 e c.113. Apenas a critério de exemplo, podemos observar o mesmo procedimento sendo utilizado com uma nota e não com um acorde. O gesto $G$, apresentado entre c.26 e c.28, termina com uma nota $\mathrm{G} \sharp 6$. Essa nota, congelada no registro superagudo, é novamente articulada em c.31, c.32 e c.34, operando também como uma espécie de centro harmônico. Seja através do congelamento de notas isoladas ou de acordes, esse procedimento será encontrado no decorrer de toda a Sonata, possibilitando a escuta de uma condução harmônica própria à peça. Porém, é importante enfatizar que tais eixos harmônicos não são atingidos através de polarizações ou tendências globais de tensão e relaxamento, mas sim através da priorização de uma ou mais alturas através de sua reiteração sistemática. 
capítulo $\mathrm{V}$ - processo 
Va. sobre a noção de processo em Berio

Em entrevista a Rossana Dalmonte, ao comentar sua experiência com o serialismo durante a década de 50, no contexto dos cursos de Darmstadt, Berio diz:

Minha primeira reação a Darmstadt e à influência benéfica de Bruno, meu primeiro exorcismo, enfim, foi Nones para orquestra, que não tem nada de darmstadtiano nem de maderniano, mas desenvolve o que era para mim o ponto central da pesquisa e da paixão musical daqueles anos: a possibilidade de pensar musicalmente em termos de processo e não de forma ou de procedimento (BERIO, 1988, p. 53).

Para compreender o que seria a noção de processo em Berio é preciso, portanto, retornar à composição de Nones, e ao início dos anos 50. Nones foi escrita em 1954 e é antecedida por Chamber Music (1953) e Cinque Variazioni (1953-54), para piano, ambas permeadas ainda pela influência de Dallapiccola. Entre 1953 e 1959 Berio participou regularmente dos cursos de Darmstadt e, nesse contexto, conheceu diversos compositores de sua geração, entre eles Pierre Boulez, Karlheinz Stockhausen, Henri Pousseur e Bruno 
Maderna $^{70}$. O contato com esses compositores colocou Berio diante das discussões e experimentações com o serialismo integral, resultando em peças com maior elaboração serial como Nones (1954), para orquestra, onde todos os parâmetros - alturas, durações, dinâmica e articulação - são submetidos à organização de diferentes séries que são articuladas entre si em torno do número nove. Na época, Nones teve grande repercussão, principalmente após uma discussão analítica apresentada por Maderna durante os cursos de Darmstadt em 1956. Em Nones a série de alturas é construída utilizando treze notas. Além da série de alturas, Nones também apresenta uma série de durações (composta por sete figuras diferentes), uma série de intensidades (composta por cinco níveis de dinâmica) e uma série de articulações (composta por três grupos de articulações variadas). Cada uma dessas séries tem suas unidades numeradas de acordo com a quantidade de elementos que as compõem, conforme demostram as figuras a seguir ${ }^{71}$ :

a) Alturas

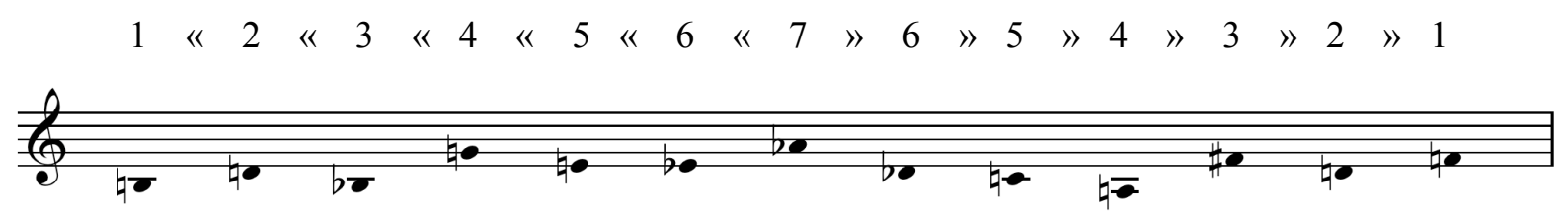

Fig. 44 - Série de alturas e seus respectivos valores, em Nones.

b) Durações

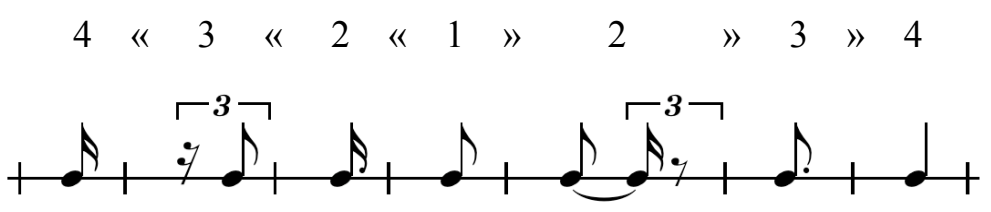

Fig. 45 - Série de durações e seus respectivos valores, em Nones.

70. Em entrevista a Rossana Dalmonte, ao comentar o ambiente de debate e produção dos cursos de Darmstadt no início dos anos 50, que teriam exercido forte influência sobre Berio, ele próprio diz: "Em 1953 Stockhausen era o eixo teórico dos Ferienkursen, Pousseur era a engrenagem especulativa, Boulez o espírito analítico e Maderna era o bom pai" (BERIO, 1988, p. 51).

71. O mapa de estruturação da peça aqui apresentado foi baseado nas próprias anotações de Berio registradas em páginas de rascunho de Nones. Ver BERIO, 1985, pp. 98-99. 
c) Intensidades

\begin{tabular}{c|c|c|c|c}
1 & 2 & 3 & 4 & 5 \\
\hline$p$ (ou $p p)$ & $m f($ ou $p p p)$ & $f$ & $f f$ & $s f f z$
\end{tabular}

Fig. 46 - Série de intensidades e seus respectivos valores, em Nones.

d) Articulações

\begin{tabular}{c|c|c}
1 & 2 & 3 \\
\hline sciolto & legato & trillo \\
tenuto & staccato & frullato \\
& & tremolo
\end{tabular}

Fig. 47- Série de articulações e seus respectivos valores, em Nones.

A partir da estruturação dessas quatro séries e da atribuição de valores numéricos às unidades que compõem cada uma delas, Berio organiza o material musical de Nones inserindo ainda um último parâmetro que dá conta de colocar essas quatro séries em operação simultânea: a soma dos valores implicados em cada som, isto é, a soma do valor de uma certa altura, com uma certa duração, em uma certa dinâmica e com uma certa articulação, deverá resultar sempre o número nove. Nones configura-se, portanto, como uma peça onde a organização serial do material composicional - expandida a alturas, durações, intensidades e articulações - é flagrante.

Tomando por referência a análise inicial do material de Nones, seria possível afirmar que a peça é exemplar no que se refere ao uso de procedimentos do serialismo integral e que, portanto, se encaixa numa suposta linha teórica de pensamento darmstadtiano do início dos anos 50. Porém, como vimos nas palavras do próprio Berio, Nones seria justamente seu primeiro "exorcismo" com relação à Darmstadt. A idéia de "exorcismo"72 aqui presente é a de

72. A idéia de "exorcismo" aparece muitas vezes em textos e entrevistas realizadas com Berio. Em diversas passagens ao longo do seu livro Berio (1991), David Osmond-Smith brinca com essa idéia corriqueiramente utilizada por Berio para apontar diversos "exorcismos" ao longo da trajetória do compositor, principalmente durante seus anos de formação. 
um mergulho aprofundado em um determinado universo para, de dentro dele, propor alguma linha de fuga. Há uma idéia de "incorporar" para "transgredir". A transgressão em Nones ocorre justamente quando se passa à aplicação concreta de toda a organização do material exposta anteriormente. $\mathrm{O}$ confronto entre o material pré-composicional e o desenrolar da peça mostra que tal organização, apesar de possuir sólidas estruturas elaboradas para os diferentes parâmetros musicais, acaba sendo diluída, paulatinamente, no interior da peça. Segundo Michel Hicks, "o exorcismo de Nones se consumou quando Berio chegou a um acordo com o serialismo de Darmstadt subjugando-o à sua poética" (HICKS, 1989, p. 265) 73. $^{73}$

Essa maneira mais livre de utilização do material serial tem origem num trabalho anterior de Berio. Assim como em Nones, nas Cinque Variazioni ${ }^{74}$ também ocorre um jogo entre momentos mais presos à estruturação serial e outros onde o aspecto melódico e temático da série acaba por conduzir a obra a terrenos distantes dessa estruturação previamente estabelecida. Segundo Osmond-Smith, Berio teria aprendido com Dallapiccola a conjugar o pensamento serial a uma atmosfera lírica:

Para Berio, assim como para vários outros jovens italianos da sua geração, a mais conveniente rota de acesso [para a música serial] foi através da música de Luigi Dallapiccola. A disciplina e o foco que Dallapiccola trouxe para a tradição lírica italiana através das técnicas seriais foi um corretivo salutar para as vaguezas da melodia neoclássica (OSMOND-SMITH, 1991, p. 6) ${ }^{75}$.

O jogo entre procedimentos seriais e tendências melódicas processuais nas Cinque Variazioni pode ser compreendido na própria constituição da série utilizada na peça. A figura abaixo mostra uma transcrição do trecho inicial da primeira variação:

73. "The 'exorcism' of Nones consisted of Berio's coming to terms with Darmstadt serialism and subjugating it to his poetics".

74. As Cinque Variazioni, compostas entre 1952 e 1953, são o segundo trabalho para piano solo de Berio. A peça dialoga com o Quaderno Musicale di Annalibera (1952) e com a ópera Il Prigioniero (1944-48), ambas de Luigi Dallapiccola, a quem as Cinque Variazioni são dedicadas. Segundo Berio (1988, p. 45), as Cinque Variazioni integrariam um conjunto de peças referidas como um mergulho no "mundo melódico" de Dallapiccola que inclui ainda trabalhos como Chamber Music (1953) e Variazioni (1955), para orquestra de câmara. Segundo OsmondSmith (1991, p. 16), as Cinque Variazioni podem ser consideradas peças pré-seriais pois apresentam certos procedimentos de permutação serial, porém de maneira muito diluída.

75. "For Berio, as for several other young Italians of his generation, the most congenial route of access was through the music of Luigi Dallapiccola. The discipline and focus that Dallapiccola brought to the Italian lyrical tradition through serial techniques was a salutary corrective to the vagaries of neoclassical melody". 


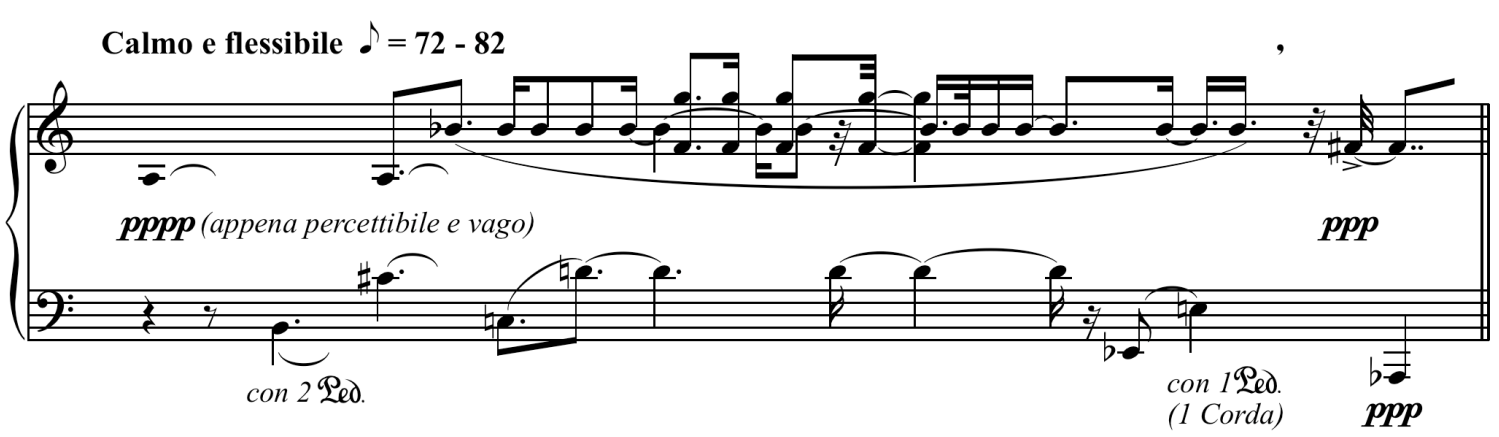

Fig. 48 - Trecho inicial de Variazione I, em Cinque Variazioni.

No trecho acima, são apresentadas as doze notas do total cromático, compondo a seguinte série: $A \sharp, B \sharp, C \sharp, B, C \sharp, D \sharp, F \sharp, G \sharp, E b, E \sharp, F \sharp e ~ A b$. A própria constituição da série evidencia a importância do intervalo de $2 \mathrm{M}$, possibilitando sua subdivisão em quatro conjunto

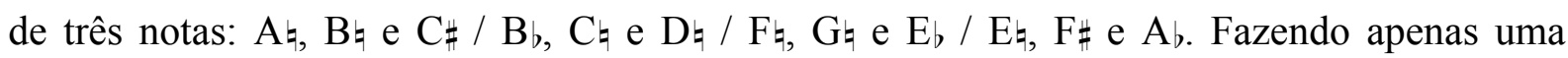
inversão na ordem das notas do terceiro grupo e enarmonizando a nota $\mathrm{A}$, do quarto grupo para $\mathrm{G} \sharp$, chega-se à seguinte estrutura:

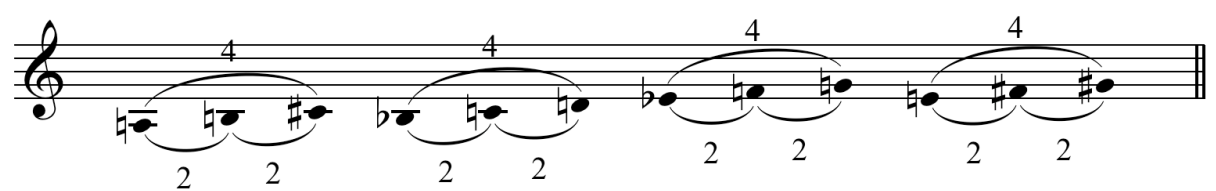

Fig. 49 - Série de doze notas apresentada no início de Variazione I, em Cinque Variazioni.

A construção da série evidencia seu potencial melódico e motívico configurandose como um agrupamento de três transposições de um pequeno fragmento intervalar representado pelo conjunto (024). Essa tendência se confirmará ao longo da análise onde a tentativa de localizar a série (ou suas derivações) de maneira sistematizada passa a ser um trabalho inócuo. Por outro lado, é possível verificar como os contornos melódicos derivados do conjunto (024) serão característicos em muitos trechos da obra. Assim, apresar de o início das Cinque Variazioni sugerir a existência de uma série de doze notas, a ordenação do material dá lugar a tendências mais melódicas e ao completo embaralhamento do que poderia ser uma série. 
Como comentamos anteriormente, o mesmo procedimento pode ser verificado em Nones, porém dentro de um contexto de utilização do serialismo integral. Em Nones, o jogo entre a estruturação serial e tendências melódicas processuais também é favorecido pela maneira como a própria série é construída. A série de treze notas utilizada em Nones é estruturada como um palíndromo, isto é, o retrógrafo da série coincide com a série original, poém transposta ao trítono. Esse efeito é gerado porque sobre o sétimo som da série, no caso a nota $\mathrm{A}$, , é estabelecido um eixo de simetria intervalar a partir do qual se observa um espelhamento dos intervalos da série. Tal estratégia propicia ainda a duplicação da nota $\mathrm{D}$ ‡ que aparece como $2^{\circ}$ e $12^{\circ}$ som da série, reforçando o trítono formado com relação à nota $\mathrm{A}$, ou seja, com o eixo da série.

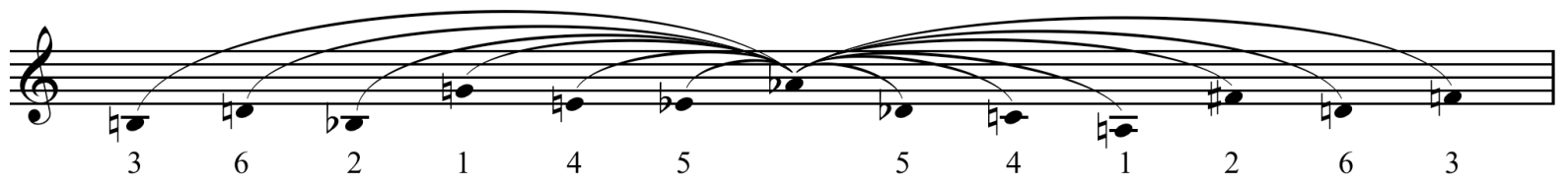

Fig. 50 - Série de treze notas em forma de palíndromo $(\mathrm{R} 0=\mathrm{P} 6)$, em Nones.

Além das polarizações sobre as notas $\mathrm{D} \sharp \mathrm{e} A$ b, outro aspecto relevante da série é a

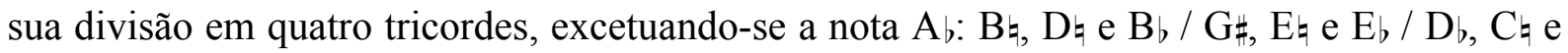
$\mathrm{A} \sharp / \mathrm{F} \#, \mathrm{D}$ q $\mathrm{F} \sharp$. Cada um dos tricordes contém o mesmo conjunto intervalar (014). Assim, Berio acaba enfatizando a formação de subconjuntos melódicos dentro da série que, no decorrer da composição, acabarão por se fixar muitas vezes como elementos temáticos, fazendo com que a peça oscile entre diferentes universos.



Fig. 51 - Tricordes gerados pela série de treze notas compondo o conjunto (014), em Nones.

Essa breve análise do material composicional das Cinque Varizaioni e de Nones nos permite compreender com maior detalhe a relação de Berio com o pensamento serial. $\mathrm{O}$ 
serialismo seria utilizado, portanto, como ferramenta para elaboração de estruturas précomposicionais quase sempre contestadas durante o percurso composicional. Em entrevista a Rossana Dalmonte, Berio afirma:

A experiência serial nunca representou para mim a utopia de uma linguagem e portanto nunca se reduziu, no meu caso, a uma norma ou a uma combinação restrita de dados. A experiência serial significa para mim, acima de tudo, uma ampliação objetiva dos recurso musicais e a possibilidade de controlar um terreno musical mais vasto, respeitando, aliás, apreciando suas premissas (BERIO, 1988, p. 55).

Desse embate entre ordem e transgressão, isto é, entre a necessidade de uma rigorosa organização prévia do material e as necessidades locais da composição, surgiria um elemento-chave para a poética de Berio: "a possibilidade de pensar musicalmente em termos de processo e não de forma ou de procedimento" (BERIO, 1988, p. 53). A diferença entre "processo" e "procedimento" é sintetizada por Hicks (1989, p. 256) da seguinte maneira:

A distinção entre os dois, que está longe de ser evidente, pode ser sintetizada da seguinte forma: para Berio "procedimento" denota uma série de passos discretos a serem tomados enquanto "processo" denota um desenvolvimento contínuo e orgânico ${ }^{76}$.

Dessa forma, do trabalho com a música serial, o que permaneceria como aprendizado para Berio seria, por um lado, a necessidade de algum sistema de organização prévia do material pré-composicional e, por outro, a importância de pensar a composição em termos de processo, colocando esse sistema em xeque a todo momento, ou seja, tendo que readequá-lo diante das necessidades locais da obra. Isso explica o comentário de David Osmond-Smith (1991, p. 7) em uma de suas análises de algumas peças seriais de Berio:

Quando Berio estabelece um reservatório de recursos pré-composicionais, ele almeja não uma abnegação forçada, mas estímulos para a imaginação que pode muito bem funcionar tanto por transgressão quanto por observância. Uma conseqüência disto é que o analista vai sempre encontrar nas partituras de Berio somente pistas e restos de um "sistema" que foi, de fato, consumido no processo de composição ${ }^{77}$.

76. "The distinction between the two, which is far from self-evident, amounts to this: for Berio 'procedure' denotes a series of discrete steps to be taken while 'process' denotes a continuous organic development".

77. "When Berio establishes a reservoir of pre-compositional resources, he aims not at a self-denying ordinance, but stimulus to the imagination that may well function as much by transgression as by observance. One consequence of this is that the analyst will often find in Berio's scores only hints or remnants of a "system" which has in effect been consumed in the process of composition". 
De uma maneira bastante simples Berio comenta essa relação entre processo e projeto pré-composicional numa passagem da entrevista concedida a Rossana Dalmonte:

Para mim, como para todos eu suponho, a primeira idéia de um trabalho é sempre global e muito geral e, aos poucos, enquanto o trabalho avança vou definindo os detalhes. [...] Seja como for, no decorrer da realização, da composição e da definição dos detalhes, pode acontecer a descoberta de novas possibilidades e novas relações nas quais possa até me deter sem alterar por causa disso a natureza e a substância do projeto. [...] No decorrer da realização do projeto global, voltando ao que eu dizia antes, ou seja, no decorrer da definição dos detalhes, pode acontecer que a descoberta e a proliferação do imprevisto se torne tão importante que acabe alterando realmente o projeto; neste caso, faço o caminho inverso: parto dos detalhes, que estava definindo e recolhendo, para chegar a um projeto diferente (BERIO, 1988, p. 75).

Para Berio, processo é, portanto, a relação entre aspectos de construção mais gerais e necessidades locais, ou seja, a maneira como se transita entre a micro e a macroestrutura de uma peça, ou ainda a maneira como se concilia o projeto précomposicional aos dinamismos concretos no ato da composição.

Esse debate sobre os conflitos entre a noção de processo e as demandas do material pré-composicional tende a soar, aos ouvidos atuais, um tanto ultrapassado. Há tempos que a noção de processo não se consolida mais como um divisor de águas dentro do campo composicional. Atualmente, pensar em termos de processo é praticamente uma atitude inquestionável para compositores de diferentes estéticas. Porém, é preciso compreender esse debate a partir de uma perspectiva histórica. Se hoje ele se tornou uma questão superada, nos anos 50 era tema para um grande volume de textos e artigos. É por isso que nos escritos de Berio - e de outros compositores durante os anos 50 e 60 - a noção de processo sempre foi muito enfatizada. A critério de exemplo, basta lembrarmos da conferência Rhythm, form and content apresentada por Varèse na Princeton University, em 1959. Nesse conferência, ao explicar as semelhanças entre a forma musical de suas composições e o fenômeno de cristalização, Varèse afirmava:

"Forma é um resultado - o resultado de um processo. Cada um dos meus trabalhos descobre a sua própria forma. Eu nunca poderia tê-los feito caber em qualquer um dos containers históricos. Se você deseja preencher uma caixa rígida, com um formato definido, você deve ter algo para colocar dentro dela que seja da mesma forma e tamanho, ou que seja elástico ou flexível o suficiente para caber dentro dela. Mas se você tentar forçar para 
dentro dela algo de um formato diferente e mais substancioso, mesmo que o seu volume e tamanho seja o mesmo, ele quebrará a caixa. Minha música não pode ser feita para caber em qualquer uma das caixas da música tradicional" (VARÈSE, 1966, p. 16) ${ }^{78}$.

Nesse ponto, podemos finalmente aproximar a idéia de processo à noção de figura, já comentada anteriormente. No Capítulo III, vimos como a idéia de processo é inerente à própria noção de gesto. É importante lembrar que, em Berio, a noção de gesto aparece como um elemento capaz de se remodelar segundo cada contexto através do estabelecimento de um processo de construção e desconstrução permanente. De maneira complementar, o pensamento de Brian Ferneyhough aponta como esse jogo de construção e desconstrução é efetivado através de transformações geradas no interior dos próprios gestos, isto é, no plano das figuras.

Em Nones, ou mesmo nas Cinque Variazioni, vimos que o material précomposicional - organização das alturas nas Cinque Variazioni e organização das alturas, durações, intensidades e articulações em Nones - é estruturado a partir de um pensamento serial que se dilui paulatinamente no decorrer das peças através de decisões processuais (nesses dois casos, norteadas pelo parâmetro melódico). Na Sonata, escrita 50 anos depois, podemos perceber um jogo dramático similar, ainda que em novo contexto. Na Sonata, o material pré-composicional não é mais delimitado a partir da elaboração serial; ele se estrutura a partir de um pensamento mais concreto (sonoro) e menos abstrato (relações de proporção). Na Sonata, o material pré-composicional é a própria coleção de gestos construída nos primeiros instantes da peça ${ }^{79}$. Assim como em Nones e em Cinque Variazioni, o que se vê ao longo da Sonata também é uma história de deformação desse material inicial; história esta que também é conduzida por decisões processuais, porém não mais ligadas somente a tendências melódicas mas, de maneira geral, a transformações de diferentes espécies geradas no interior dos próprios gestos, isto é, no plano das figuras.

78. "Form is a result - the result of a process. Each of my works discovers its own form. I could never have fitted them into any of the historical containers. If you want to fill a rigid box of a definite shape, you must have something to put into it that is the same shape and size or that is elastic or soft enough to be made to fit in. But if you try to force into it something of a different shape and harder substance, even if its volume and size are the same, it will break the box. My music cannot be made to fit into any of the traditional music boxes".

79. Aqui reside uma importante diferença entre o material pré-composicional da Sonata e o de Nones e das Cinque Variazioni. Na Sonata os gestos não são estruturados num plano separado da composição; eles são construídos no próprio tempo da composição. As três categorias de Xenakis (1994, pp. 94-105) a respeito da estruturação do tempo na composição - hours-temps, en-temps e temporelle - nos ajuda a compreender essa distinção. O material pré-composicional de Nones e de Cinque Variazioni, ou seja, a série, é uma estrutura entemps - isto é, que depende de uma diacronicidade mas que se dá fora do tempo concreto da composição - ao passo que na Sonata, os gestos se constituem como estruturas essencialmente temporelles - isto é, que se formam dentro do tempo concreto da composição. 
Nos Capítulos III e VI observamos com detalhe a construção de cada um desses gestos iniciais. No presente capítulo interessa-nos verificar como esses gestos iniciais se desenrolam ao longo da peça, isto é, de que maneira eles são transformados dentro de um pensamento processual que é conduzido pelo trabalho figural. Falar de processo na Sonata é, portanto, falar dos gestos em operação, dos seus dinamismos, daquilo que dentro dele se movimenta e se transforma, isto é, de suas figuras. 


\section{Vb. processo na Sonata}

Nesse tópico observaremos o caráter processual dos gestos dentro da Sonata verificando o que chamamos de uma história energética de cada um deles. Essa história energética indicará certas deformações sofridas (ou provocadas) por cada gesto ao longo da peça. É observando esse caráter processual (figural) dentro da Sonata que poderemos compreender como um conjunto limitado a apenas oito gestos pôde organizar uma peça de grande extensão.

\section{$\underline{\text { história energética do gesto Z }}$}

$\mathrm{O}$ gesto $\mathrm{Z}$, caracterizado pela repetição lenta e regular de uma mesma nota, mais especificamente de um $B, 4$ e que tem sua ressonância garantida pelo uso do pedal tonal, sofre diversas alterações no decorrer da Sonata. No início da peça são configuradas duas camadas: a camada I é estável e tem um material fixo, o próprio gesto Z; a camada II é mais dinâmica, sendo composta pelos demais gestos que são apresentados paulatinamente. A percepção de duas camadas bem delimitadas no início da peça é reforçada pelo desencontro rítmico que há entre ambas: enquanto o gesto $Z$ é pulsado em semínimas regulares, os demais gesto são 
introduzidos em contratempos (em relação à pulsação de Z). Chamaremos esse tipo de configuração de sobreposição gestual (que será representada pelo uso de uma barra diagonal: / ). A figura a seguir mostra os cinco primeiros compassos da peça, onde tem início a formação dessas duas camadas descritas:

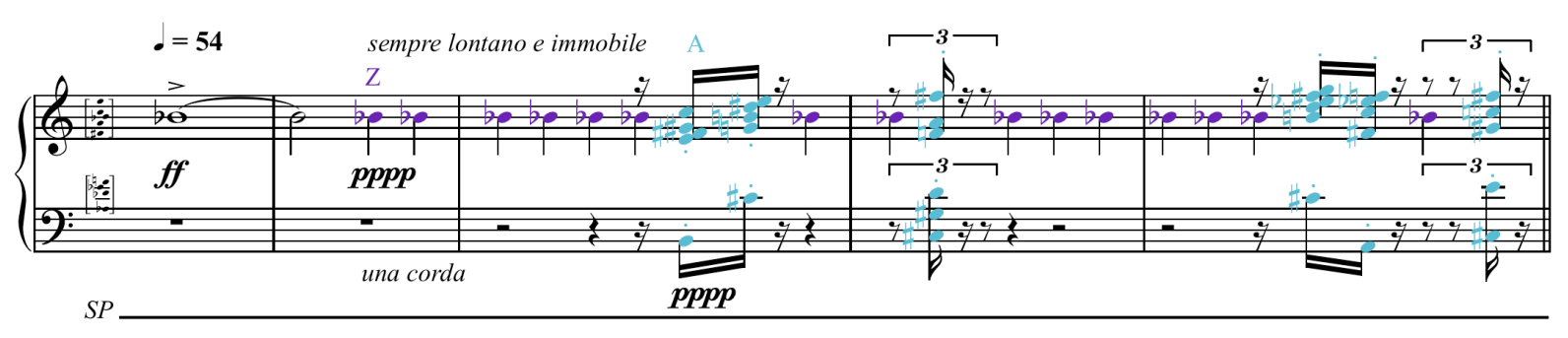

Fig. 52 - (A/Z): sobreposição dos gestos A e Z , c.1 a c.5.

Em alguns momentos surgem breves pontos nodais entre as duas camadas, atingidos pela convergência rítmica entre o gesto $\mathrm{Z}$ e os demais gestos, fazendo com que as camadas entrem, provisoriamente, "em fase". Um primeiro exemplo dessa situação pode ser observado no quarto tempo de c.6 (Fig. 53), quando o gesto B converge com a pulsação do gesto $\mathrm{Z}$ gerando, pela primeira vez, um ponto nodal entre as camadas I e II. A sobreposição "em fase" dos gestos B e Z pode ser observada também no início de c.8, com uma pequena variação gerada pela figura do arpeggio no gesto B. Em c.7 um novo ponto nodal é estabelecido através do encontro rítmico nas sobreposição dos gestos A e Z. O mesmo efeito pode ser observado em c.9, onde o gesto A passa para um registro mais grave que o do gesto Z. Todos esses pontos de convergência permitem uma aproximação entre as duas camadas porém não provocam modificações estruturais em cada um dos gestos. Através dessas sobreposições os gestos se aproximam e se afastam sem que um interfira na estrutura do outro.

Um choque um pouco mais acentuado ocorre no primeiro tempo de c.12 onde, pela primeira vez, o gesto $Z$ tem sua pulsação interrompida pela introdução inesperada do gesto $\mathrm{C}$ que, com dinâmica $f f$, rompe com a sonoridade em pianíssimo característica do início da Sonata. Porém, observando com maior detalhe, nota-se a presença marcante da nota $\mathrm{B}, 4$ como parte de três dos cinco blocos harmônicos que compõem essa figura. De certa maneira, o gesto $\mathrm{Z}$ se dilui no interior do gesto $\mathrm{C}$. Aqui não se trata apenas de uma sobreposição "em 
fase" entre diferentes gestos. A esse tipo de configuração, onde um determinado gesto adquiri características figurais de um segundo gesto, chamaremos de modulação gestual (que será representada pelo uso de um sinal de multiplicação: x ). A figura abaixo exemplifica cada um dos pontos nodais acima descritos:
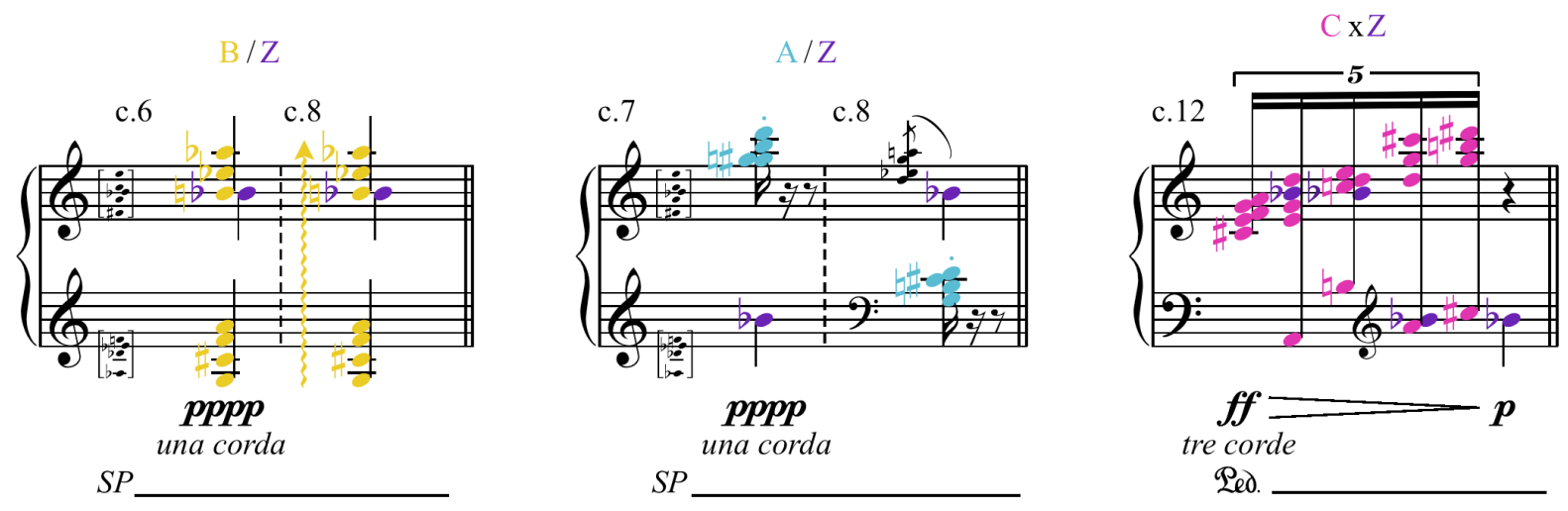

Fig. 53 - (A/Z), (B/Z) e (ZxC): sobreposição entre os gestos Z e A, Z e B, e modulação entre os gestos $\mathrm{Z}$ e $\mathrm{C}$.

Após esses breves "curtos-circuitos" com os gestos A, B e C, o gesto Z sofre uma modificação estrutural significativa em c.14 onde, pela primeira vez, a figura caracterizada pelo pulso regular em semínimas é alterada pela introdução de uma semínima pontuada. Como vimos no Capítulo IV, no tópico sobre ritmo (Fig. 33), o gesto Z sofrerá deslocamentos do pulso similares a esse no decorrer de toda a Sonata. Em c.21, por exemplo, o pulso é novamente desacelerado com a introdução de um figura composta pela nota $\mathrm{B}, 4 \mathrm{em}$ mínima. Já em c.19 é possível observar a situação contrária quando a nota $\mathrm{B}, 4$ é apresentada como uma colcheia. Essas modificações figurais são relevantes pois quebram a regularidade rítmica característica do gesto $\mathrm{Z}$ no início da peça. A partir desse ponto, o gesto $\mathrm{Z}$ incorporará o jogo de permanência e impermanência de um mesmo pulso, criando zonas mais ou menos regulares.

A divisão da textura em duas camadas distintas através das sobreposições será modificada paulatinamente. Até c.28, são apresentados os gestos de A, B, C, D, E e G, de maneira bastante clara e espaçada. A partir de c.29, a camada II tende a se complexificar, aproximando temporalmente os diferentes gestos. Pouco a pouco, a camada I torna-se menos nítida e as duas camadas passam a se misturar com maior freqüência. Pontos nodais como aqueles observados no início da Sonata começam a ocorrer em maior volume e o gesto Z 
passa a ser diluído gradativamente. Esse processo culminará na completa dissolução da camada I a partir de c.76 onde o gesto $\mathrm{Z}$, que persistia de maneira ininterrupta durante todo o trecho inicial da Sonata, sucumbe definitivamente à interferência do gesto E. A partir de c.77, é relevante observar ainda que, pela primeira vez em toda a peça, a nota $\mathrm{B}, 4$ não é mais sustentada pelo pedal tonal. Dessa maneira, é possível identificar o trecho em questão como o momento de diluição total do gesto $\mathrm{Z}$.

Porém, uma nova configuração do gesto $Z$ passa a se estruturar mais adiante, a partir de c.89, quando o gesto $\mathrm{F}$, caracterizado pela repetição de uma mesma nota em ritmo constante e em alta velocidade, repousa sobre uma nota $\mathrm{B}, 4$, remetendo-se imediatamente ao gesto $\mathrm{Z}$. Os gestos $\mathrm{F}$ e $\mathrm{Z}$ possuem características figurais muito similares: ambos tratam da repetição de uma mesma nota e são marcados pela regularidade de durações. Porém, enquanto o gesto $\mathrm{Z}$ trabalha com figuras de longa duração, o gesto $\mathrm{F}$ é concentrado em grupos de figuras curtas (fusas). Em c.89 ocorre então uma modulação entre as tendências figurais dos gestos F e Z.

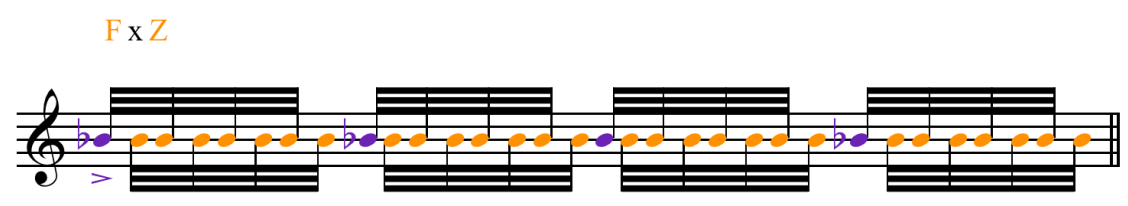



Esse processo será repetido diversas vezes na parte central da Sonata, criando algumas ilhas em torno da nota $\mathrm{B}, 4$ repetida (figura característica do gesto $\mathrm{Z}$ ) que passa a ser conduzida não mais por semínimas mas sim por grupos de fusas (figura característica do gesto F). Uma situação peculiar de modulação entre os gestos $\mathrm{F}$ e Z pode ser observada em c.146 e c.147. Esses dois compassos constituem o ponto conclusivo de uma transição entre diferentes gestos iniciada em c.137 e que será comentada posteriormente. Entre c.137 e c.145, a nota B,4 é articulada repetidas vezes, ainda que distanciadas temporalmente, em sobreposição a outros gestos. Em c.146 todo o movimento gestual converge para a nota $\mathrm{B}, 4$ que se estabiliza sobre grupos de fusas. Em seguida, há uma retenção global do movimento: através de uma indicação de rallentando a nota $\mathrm{B}, 4$ é conduzida ao gesto $\mathrm{Z}$ que se desenrola ainda sobre um 
desacelerando escrito até repousar, finalmente, sobre uma figura longa de mínima. Dessa maneira, o grupo de fusas sobre a nota $\mathrm{B}, 4$ desempenha um papel importante de transição entre o acelerado movimento gestual que o antecede (concentrado sobre grupos de fusas em quiálteras) e o retorno do gesto Z, que o sucede. É relevante observar que, entre c.137 e c.147, a nota $\mathrm{B}, 4$ (grafada como $\mathrm{A} \sharp 4$ ) volta a compor o conjunto de notas sustentadas pelo pedal tonal, recuperando uma maior ressonância a partir do trecho em questão.



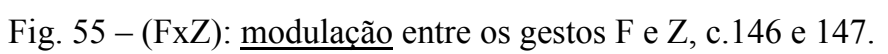

É importante notar que situações como essa - onde o gesto $Z$ recupera sua característica figural inicial de pulsação lenta - serão exceção após sua modulação com o gesto F, ocorrida em c.89. O choque entre os dois gestos provocará uma guinada irreversível na história energética do gesto $\mathrm{Z}$ que, até o fim da Sonata, passará a acontecer essencialmente sobre figuras de alta velocidade (fusas).

A figura abaixo mostra, a título de exemplo, uma das poucas exceções onde uma certa memória da figura rítmica inicial do gesto $\mathrm{Z}$ é recuperada. Trata-se do compasso 162, onde um bloco vertical - que inclui a nota $\mathrm{B}, 4$ - é repetido em pulsação regular de semínimas. Nesse momento, o gesto $\mathrm{Z}$ não aparece mais modulado pelo gesto $\mathrm{F}$, mas sim pelo gesto $\mathrm{B}$. $\mathrm{O}$ compasso em questão condensa, portanto, uma característica figural própria ao gesto B (bloco vertical com durações longas) e outra própria ao gesto $\mathrm{Z}$ (nota repetida e pulsação regular). Aqui não se trata nem do gesto $\mathrm{B}$ e nem do gesto $\mathrm{Z}$ mas novamente de uma modulação entre características figurais de dois gestos distintos: 


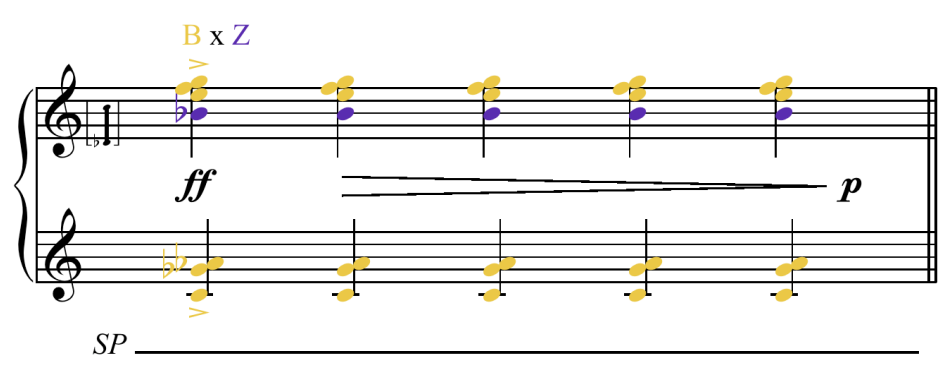



Após o compasso 162, o gesto Z passará um longo período sem ser claramente articulado dentro da Sonata. A partir de c.286 a nota B,4 passa a integrar novamente o conjunto de notas sustentadas pelo pedal tonal, permanecendo até o fím da peça como uma nota de grande ressonância. Em c.294 o gesto Z volta a ganhar importância, porém sempre modulado pelo gesto F. A insistência sobre a nota $\mathrm{B}, 4$ terá seu ponto culminante em c.306, com a ampliação da dinâmica para um fortissimo. Uma última aparição do gesto $Z$, ainda com a deformação gerada pela figura característica do gesto $\mathrm{F}$, acontecerá nos compassos finais da peça, em c.334 e c.335, recuperando certa memória do início da Sonata com a reiteração da nota $\mathrm{B}, 4$, que é articulada ainda uma última vez no compasso final.

\section{história energética do gesto A}

O gesto A, com grande participação entre c.1 e c.17, será recorrente durante toda a Sonata, porém de maneira menos concentrada do que quando apresentada no início. O gesto A, caracterizado inicialmente pela sonoridade em pppp sofrerá alterações de intensidade ao longo da peça, porém ele se manterá, na maior parte das vezes, dentro de uma dinâmica que vai do pianíssimo ao mezzo-forte. O gesto A também está presente em Interlinea, porém na Sonata, ele desempenha um caminho energético diferente. Em Interlinea, o gesto A aparece somente em c.19, após já terem sido apresentados os gestos B, D, E e F, ou seja, ele não compõe a atmosfera inicial da peça como acontece na Sonata. Outra característica importante em Interlinea é que o gesto A é apresentado pela primeira vez em forma de cluster para, somente a partir de c.45, aparecer como acorde. Na Sonata, a história do gesto A segue a direção contrária: o gesto A é apresentado inicialmente com uma figura de estrutura mais 
harmônica para, num segundo momento, a partir de c.88 (correspondente de c.19 em Interlinea), aparecer com uma estrutura mais inarmônica, ruidosa, gerada pelo uso do cluster. Num momento posterior, quando verificarmos a história energética do gesto $\mathrm{C}$, observaremos que essa variação harmônica introduzida no gesto A com a introdução dos clusters, contaminará também o gesto $\mathrm{C}$.

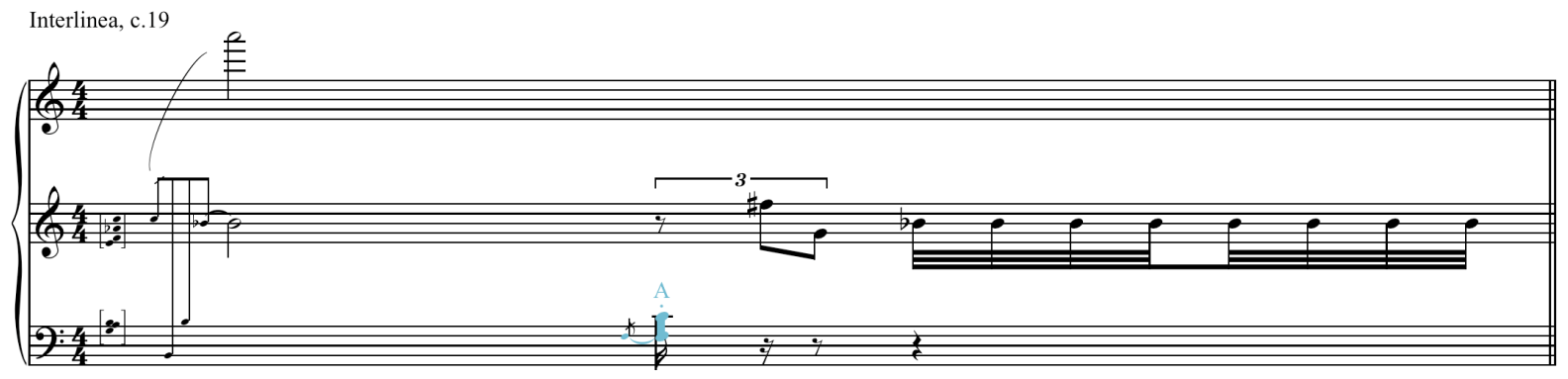

SP

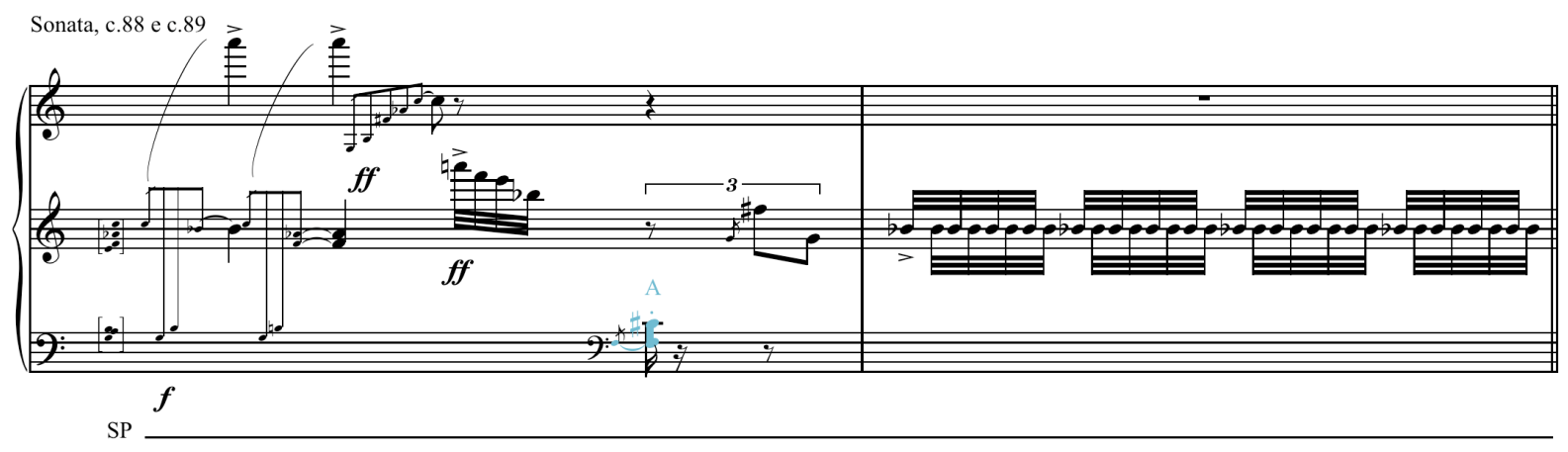

Fig. 57 - Gesto A em forma de cluster em c.19 de Interlinea e em c.88 da Sonata.

A partir de c.111 o gesto A passará a aparecer sempre combinado ao gesto B, compondo juntos uma nova figura. A esse tipo de configuração, onde dois gestos são combinados por justaposição para comporem uma nova figura, chamaremos de agrupamento gestual (que será representado pelo uso de um sinal de soma: + ). Essa tendência de combinação entre características dos gestos A e B pode ser verificada em vários pontos da Sonata e irá culminar na estabilização de uma nova figura a partir de c.216, conforme veremos adiante (Fig. 61). O exemplo abaixo apresenta alguns pontos intermediários da Sonata onde é possível verificar breves agrupamentos formados pelos gestos A e B: 

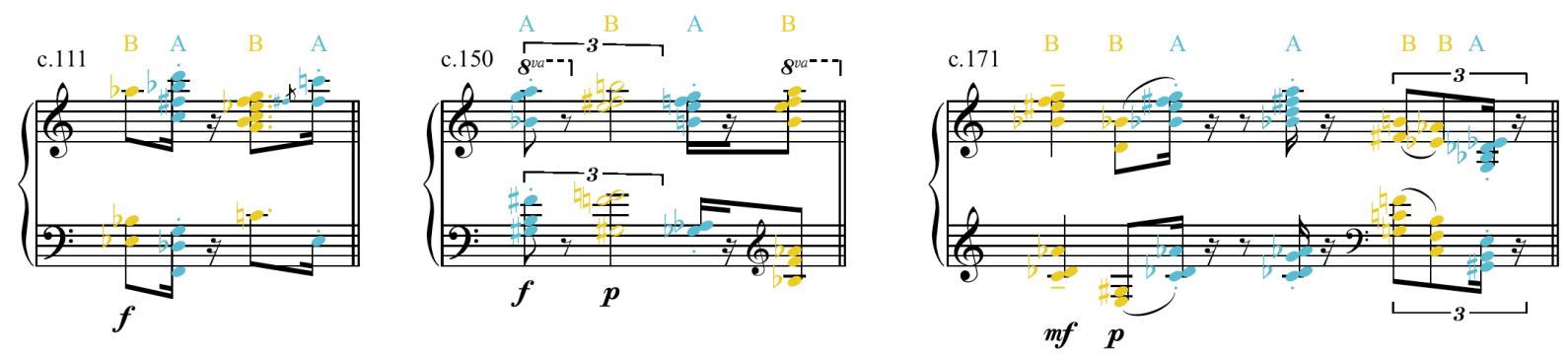

Fig. $58-(\mathrm{A}+\mathrm{B})$ : agrupamentos entre os gestos A e B.

O gesto A, em sua configuração inicial, voltará a ganhar força nos minutos finais da peça. É ele, por exemplo, que marca o fím de Interlinea dentro da Sonata, em c.315. Em c.337, último compasso da Sonata, temos ainda a presença do gesto A como o último elemento articulado na peça, reforçando uma memória do início da Sonata.

\section{história energética do gesto B}

O gesto $\mathrm{B}$, incorporando especialmente a articulação em arpeggio, também estará presente durante toda a peça, em geral desempenhando o papel de reter (ou contrabalançar) a aceleração do movimento de outros gestos. Este é um gesto oriundo de Interlinea, sendo o responsável pela primeira citação mais direta dessa peça dentro da Sonata, em c.72. Como vimos, na parte central da Sonata, mais especificamente em c.162, o gesto B passará por uma modulação com o gesto Z (Fig. 56). Um situação similar pode ser observada em c.186 (Fig. 59) onde novamente uma dupla interpretação é possível: o gesto $Z$ passa a ocorrer sobre formações verticais - figura característica do gesto B - ou o gesto B passa a ocorrer sobre acordes repetidos - figura característica do gesto $\mathrm{Z}$ (notar presença do $\mathrm{B}, 4$ ). A partir desse ponto, o gesto B passa a incorporar as características de repetição e de pulsação regular próprias ao gesto $\mathrm{Z}$, sem necessariamente se utilizar da nota $\mathrm{B}, 4$. 






Como vimos anteriormente, o gesto $\mathrm{B}$ tende a se agrupar com o gesto A, resultando em novas figuras. O trecho compreendido entre c.197 e c.229 é exemplar nesse sentido. De acordo com a análise realizada no Capítulo II (ver Quadro Comparativo A, Fig. 2), tal trecho não possuía, a princípio, uma correlação direta com Interlinea, configurando-se como uma seção própria à Sonata. Porém, a partir da percepção de um agrupamento recorrente entre os gestos A e B durante toda a peça, pode-se notas que a figura utilizada no trecho em questão tem sua origem nesses dois gestos, presentes tanto em Interlinea quanto na Sonata. Esse trecho, compreendido entre c.197 e c.229, pode ser dividido em duas partes: uma primeira de c.197 até c.215 e uma segunda de c.216 a c.229. Na primeira parte, um acorde é gradativamente construído na mão direita, na região médio-grave do piano. A reiteração de um perfil harmônico global (ainda que com pequenas variações) não deixa de ser reflexo da contaminação sofrida pelo gesto B após sua modulação com o gesto Z. A figura abaixo mostra alguns pontos relevantes nesse processo que culmina, em c.216, no acorde formado pelas notas $\mathrm{D}, \mathrm{E}, \mathrm{B}, \mathrm{E} b^{80}$ :



Fig. 60 - Construção harmônica conduzida pelo gesto B entre c.197 e c.215.

80. Esse processo de construção gradativa de um aglomerado harmônico que depois de completo é congelado num determinado registro, perpetuandopelos compassos seguintes, foi abordado anteriormente no Capítulo IV, no tópico reservado ao comentário de alguns recursos harmônicos utilizados na peça. 
A segunda parte do trecho em questão, que se estende de c.216 a c.229, está centrada sobre esse último acorde apresentado na Fig. 60. Nessa segunda parte, vemos o agrupamento formado pelos gestos A e B (ver c.111 na Fig. 58) ganhar força. Assim, o trecho é inteiramente construído por agrupamentos de acordes longos (gesto B) e curtos (gesto A), sobre uma harmonia que se repete como uma espécie de ostinato (gesto Z). Esse é um exemplo bastante rico no que se refere à possibilidade de gerar novas figuras a partir de transformações provocadas no interior de gestos que já estejam em circulação dentro da peça. Dessa maneira, o trecho indicado na partitura como quasi jazz, aparentemente estranho ao material inicial da Sonata, pode ser compreendido como uma derivação figural dos gestos A, B e C. Esse trecho se consolida como um momento de estabilização, ainda que provisória, de uma nova figura gerada por choques e deformações resultantes do encontro de diferentes gestos.

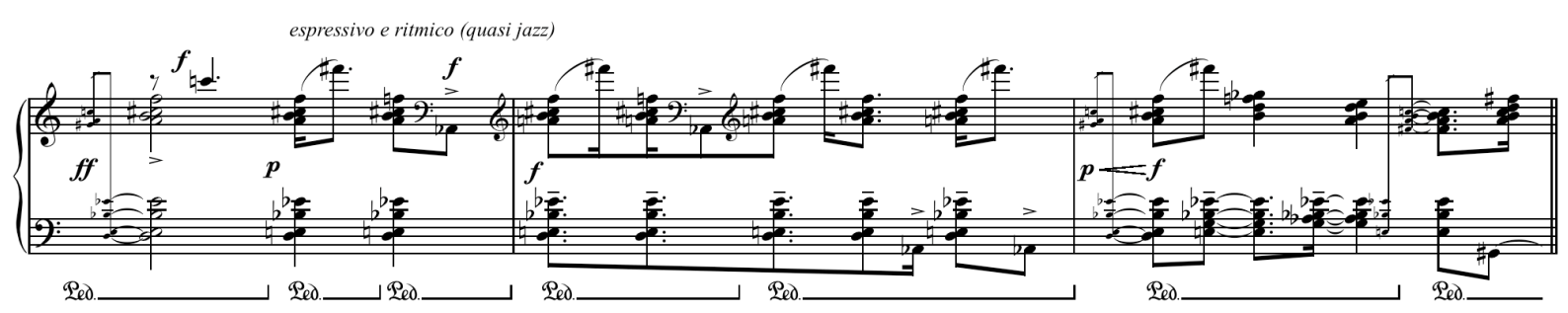

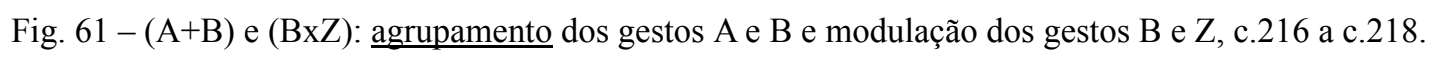

A figura estruturada entre c.216 e c.218 terá ainda um desdobramento próprio, gerando o material que é apresentado entre c.219 e c.223. Nesses compassos, a linha apresentada pela mão direita é reduzida em sua carga harmônica e torna-se mais melódica. Esse desdobramento é relevante pois ele dará origem ao material que será apresentado mais adiante, entre c.249 e c.261, e que a princípio também integrava um dos trechos sem correlações com Interlinea (ver Quadro Comparativo A, Fig. 2). Sob essa nova perspectiva, esse material pode ser compreendido como um desdobramento da combinação entre as figuras dos gestos A, B e Z. 


\section{história energética do gesto $\mathrm{C}$}

$\mathrm{O}$ gesto $\mathrm{C}$, com presença marcante no início da peça, permanecerá um longo período sem ser utilizado, voltando a ganhar força no trecho compreendido entre c.137 e c.145, onde se desenrola sobre uma grande seqüência de acordes em movimento rápido, com perfil em ziguezague, porém com uma significativa modificação harmônica gerada pelo uso sistemático de clusters. O uso do cluster indica uma característica harmônica em comum com o gesto A que já havia passado a se constituir sobre figuras de clusters desde c.88 (Fig. 57).

O trecho compreendido entre c.137 e c.145 também mostra a relação entre o gesto $\mathrm{C}$ e o gesto $\mathrm{E}$ (caracterizado por uma linha horizontal em alta velocidade, com perfil em ziguezague). $\mathrm{O}$ que diferencia os gestos $\mathrm{C}$ e $\mathrm{E}$, essencialmente, é o fato de que o gesto $\mathrm{C}$ apresenta uma figura que se consolida sobre blocos e o gesto E, sobre linhas. No trecho em questão, Berio promove uma transição gestual entre eles (que será representada pelo uso de um traço: - ). Assim, em c.137, num movimento melódico rápido, em ziguezague, percebe-se com nitidez a figura característica do gesto E. Já a partir de c.138, essa figura é gradualmente desfocada através do acréscimo de alguns intervalos harmônicos até que, no fim de c.138, ela culmina em blocos de clusters transferindo o foco ao gesto C. O gesto C se estende até c.142, quando tem início um processo de retorno ao gesto $\mathrm{E}$ através da diluição dos clusters e da retomada de uma figura mais melódica do que acordal.
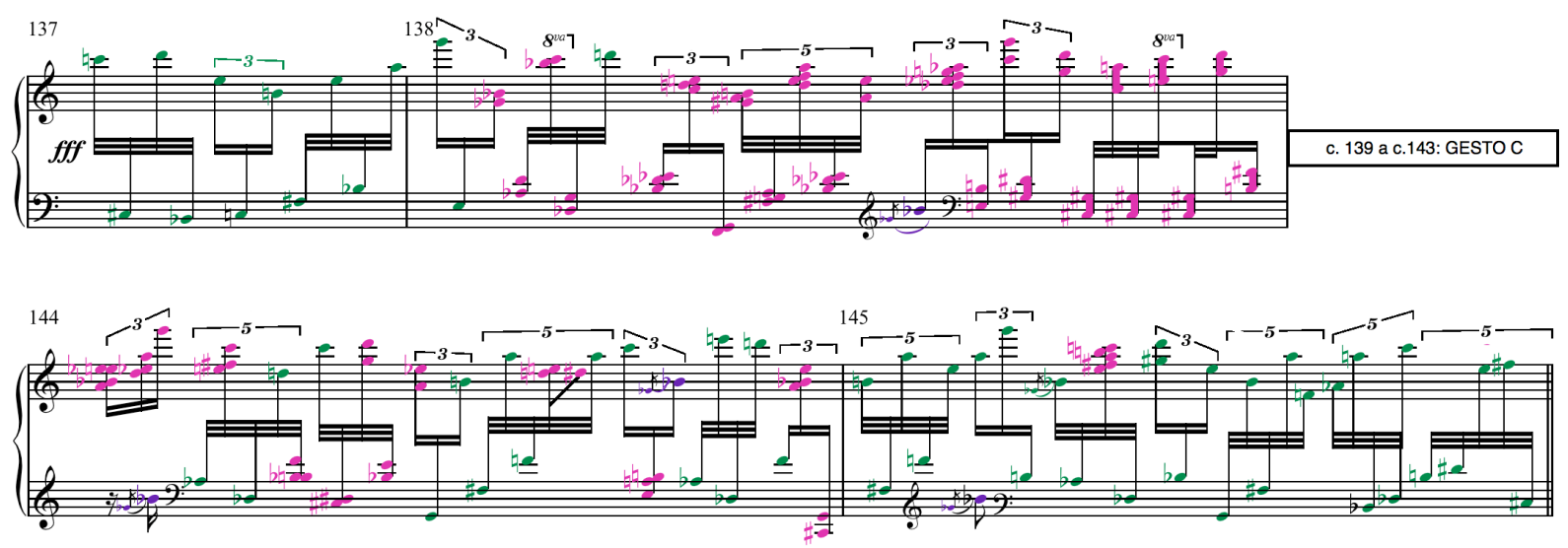

Fig. 62 - (E - C - E): transição entre o gestos E e C, c.137 a c.145 
Assim, através de um processo de acúmulo e diluição de notas, isto é, através de transformações conduzidas no interior da estrutura harmônica desses gestos, o trecho em questão apresenta uma transição “em vaivém" entre os gestos C e E que resulta no adensamento e na rarefação da textura ${ }^{81}$. No trecho em questão o gesto $\mathrm{C}$ ganha maior mobilidade rítmica, utilizando-se de uma maior variedade de figuras rítmicas (tercina de semicolcheias, quartina e quintina de fusas). $\mathrm{O}$ gesto $\mathrm{C}$ terá um comportamento similar a esse em c. 161 , c. 163 a c. 165 , c.172, e c.223 a c.224, retornando às suas características iniciais a partir de c.296 e retomando inclusive a indicação de expressão “violento”.

\section{história energética dos gestos D, E e F}

O gesto D - caracterizado por uma linha horizontal em movimento direcional, com ritmo constante e em alta velocidade (figuras de fusas) ${ }^{82}$ - sofrerá algumas transformações ao longo da peça, aparecendo em figuras que combinam os movimentos ascendente e descendente, possibilitando assim seu crescimento temporal. Em sua primeira aparição, em c.14, o gesto D era executado por uma figura em movimento ascendente, somando oito fusas. Em c.56, o gesto D já aparece com uma figura que justapõe uma linha direcional descendente $(\mathrm{G}-\mathrm{A}, \mathrm{b})$ a outras duas linha ascendentes $(\mathrm{A},-\mathrm{F}$ e $\mathrm{G}-\mathrm{D})$, possibilitando uma ampliação de oito para dezesseis fusas. Dessa maneira, através de combinações de figuras com direções ascendentes e descendentes, o gesto D passa a crescer em tamanho dentro da peça. Além da justaposição de movimentos ascendente e descendente, o gesto D também aparecerá em figuras que se utilizam da sobreposição dos dois movimentos, como se pode observar a partir de c.128. A justaposição e a sobreposição do gesto D terá grande

81. Esse trecho integra uma seção de transição dentro da Sonata que tem início em c.137 e se estende até c.147, passando por cinco gestos diferentes, entre eles os gestos C e E. Essa transição tem início em c.137 com o gesto $\mathrm{D}$, que antecede a entrada do gesto E. A partir de c.138 o gesto E passa a ser adensado, resultando no gesto C. Um pouco mais adiante, a partir de c.140, o gesto C passa a ser perturbado por insistentes reiterações da nota $B, 4$ que acaba operando como um eixo de atração harmônica, como uma força centrípeta, dentro dessa transição. Em c.144 tem início um caminho contrário àquele descrito a partir de c.138. Através de um processo de rarefação, o gesto C retorna gradativamente ao gesto E, se consolidado em c.145. Entre c.145 e c.146 há um processo de compressão da tessitura do gesto $\mathrm{E}$, isto é, uma espécie de afunilamento que converge no gesto $\mathrm{F}$ no fim de c.146 e, finalmente, no gesto Z, em c.147. De maneira resumida, essa transição coloca cinco (dos oito gestos) em relação e opera uma transição gestual na seguinte ordem: $\mathrm{D}-\mathrm{E}-\mathrm{C}-\mathrm{E}-\mathrm{F}-\mathrm{Z}$.

82. É importante notar que os gestos D e E aparecem grafados no início da peça como grupos de fusas dentro de uma semínima de tercina. Porém, a partir de c.71, eles passam a aparecer como grupos de fusas dentro de uma semínima simples. Tal alteração de grafia ocorre para compensar a alteração do andamento que, no primeiro caso, é de semínima $=54$ e, no segundo caso, de semínima $=81$. Portanto, apesar das diferentes grafias, os gestos não sofrem desaceleração rítmica. 
relevância na parte final da peça, entre os c.309 e c.315, conduzindo para o fim de Interlinea dentro da Sonata.

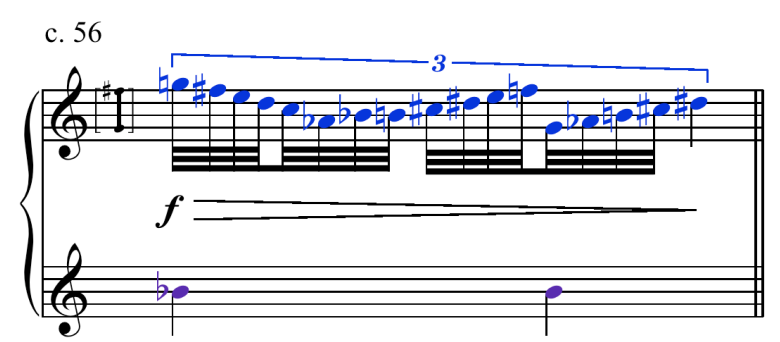

(SP)

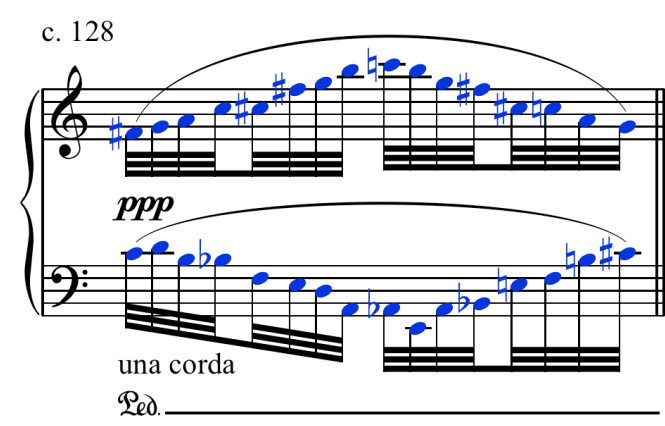

Ted.

Fig. 63 - Transformações do gesto D: justaposição em c.56 e sobreposição em c.128.

Ao longo da peça, o gesto D sofrerá uma maior aceleração do movimento e passará a ser grafado também como um grupo de apojaturas. Na parte final da Sonata, o gesto D é apresentado ora em figuras que se utilizam do grupo de fusas, ora em figuras que se utilizam de apojaturas, muitas vezes com notas iguais. Isso pode ser verificado entre c.312 e 314, por exemplo, onde seqüências de notas idênticas (ou com pequenas variações) são apresentadas ora como fusas, ora como apojaturas ${ }^{83}$.

O gesto E, caracterizado por uma linha horizontal com perfil em ziguezague, com ritmo constante e em alta velocidade, estará presentes durante toda a Sonata e, assim como o gesto $\mathrm{D}$, sofrerá um processo gradativo de crescimento, ampliando-se a cada vez em número de notas. Em sua primeira aparição, em c.15, o gesto E se desenrola sobre uma figura com oito ataques. No compasso seguinte, essa figura é ampliada para doze ataques. Entre os compassos 39 e 40, o gesto E já aparece com vinte ataques e, em c.55, com vinte e quatro ataques. Entre c.90 e c.91 é possível verificar mais uma expansão do gesto E, que aparece com vinte e oito ataques. Entre c. 95 e c.96, o gesto E é ampliado para trinta e dois ataques e, finalmente, entre c.145 e 146, ele aparece em sua versão mais dilatada, somando um total de quarenta e cinco ataques. Após esse trecho, o gesto E será gradualmente reduzido em tamanho (porém de maneira não-linear). Como vimos no Capítulo IV, o gesto E apresenta um crescimento não somente em quantidade de sons por figura, mas também em variedade de notas (Fig. 36).

83. Assim como o gesto D, os gesto E e F também aparecerão - ainda que em menor quantidade - grafados como um grupos de apojaturas. Isso pode ser verificado entre c. 80 e c. 82 no gesto F, e em c. 188 no gesto E. 
Outra transformação importante na figura do gesto E acontece a partir de c.71. Até então, as figuras se restringiam a um âmbito compacto que priorizava movimentos de segundas e terças com eventuais saltos, porém compreendidos ainda dentro de uma oitava. Em c.71 o gesto E apresenta um novo comportamento, espalhando-se sobre diferentes registros. Dessa maneira, o gesto E passará a operar sobre duas figuras diferentes: uma de âmbito compacto e outra de âmbito expandido.


Fig. 64 - Diferentes figuras do gesto E: âmbito compacto em c.55 e âmbito expandido em c.71-72.

Uma última transformação figural relevante dentro do gesto E ocorre em c.148. Nesse compasso, o gesto E passa a se estruturar sobre uma seqüência de tercinas de semicolcheias e não mais sobre figuras de fusas. Porém, tal alteração é introduzida apenas para compensar uma modificação no andamento que passa nesse trecho para semínima $=104$. A grande transformação figural sofrida pelo gesto $\mathrm{E}$ a partir desse ponto é que ele passa a reunir duas linhas melódicas horizontais, em geral em movimentos contrários, resultando num adensamento de sua textura. Essa nova figura do gesto E será novamente apresentada entre c.153 e c. 155 , e c.157 e c. 160 . O gesto E voltará à sua textura inicial a partir de c.187.



Fig. 65 - Gesto E com adensamento da textura, em c.148 e c.149. 
$\mathrm{O}$ gesto $\mathrm{F}$, caracterizado pela repetição constante e em alta velocidade de uma mesma altura, é apresentado na Sonata somente a partir de c.79. Em sua primeira aparição, o gesto $\mathrm{F}$ se estabiliza sobre a nota $\mathrm{F} \sharp 4$ e conta com vinte e nove ataques repetidos. Porém, ao longo da peça, a figura do gesto $\mathrm{F}$ passará por duas importante transformações: variação da nota repetida e variação da quantidade de ataques (compressão ou dilatação temporal). $\mathrm{O}$ gesto F não atinge o total cromático. Considerando todas as suas aparições, ele se concentra apenas sobre sete notas: $\mathrm{E} \sharp 4, \mathrm{~F} \sharp 4, \mathrm{~F} \sharp 4, \mathrm{G} \sharp 4, \mathrm{G} \sharp 4, \mathrm{~A} \sharp 4$ e $\mathrm{B}, 4$. O quadro abaixo apresenta de maneira sucinta todas as variações do gesto F dentro da Sonata, indicando passo-a-passo por quais notas ele passa e com quantos ataques ele aparece a cada vez.

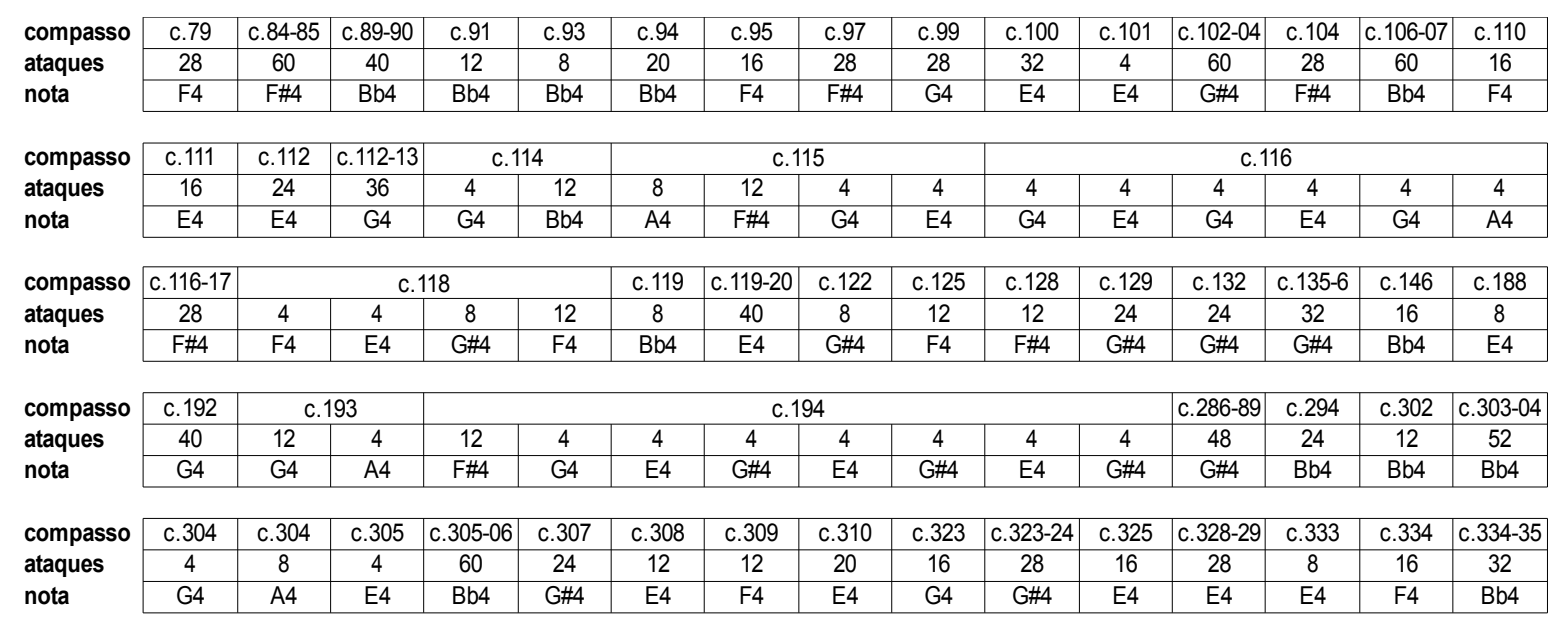

Fig. 66 - Todas as aparições do gesto F: notas e quantidade de ataques.

A leitura desse quadro (Fig. 66) nos permite verificar momentos de maior estabilidade harmônica - gerada pela longa permanência sobre uma determinada nota, como é o caso dos trechos compreendidos entre c.84 e c.85, c.102 e c.104, c.106 e c.107, c.303 e c.304, c.305 e c.306, entre outros - e momentos onde há uma grande instabilidade harmônica - gerada pelo deslocamento constante do gesto F por diferentes alturas, como em c.116, c.118 e c.194, por exemplo, nos quais o gesto F transita por diferentes alturas num curto espaço de tempo. Nos trechos de maior instabilidade, a oscilação do gesto F sobre diversas notas confere à peça um maior adensamento harmônico. 
Os gesto D, E e F apresentam diversas semelhanças. Como vimos, eles têm origem num único gesto presente em Interlinea (Fig. 24). Esses três gestos se caracterizam por uma figura melódica em ritmo rápido (fusas) e constante, diferenciando-se somente através de variações de contorno, isto é: perfil direcional, perfil em ziguezague ou perfil de notas repetidas. Por conta dessa familiaridade, os gestos D, E, e F tendem a se agrupar entre si de diferentes maneiras ao longo da Sonata. Esses agrupamentos caracterizam longos trechos dentro da peça, como por exemplo aquele compreendido entre c.79 e o primeiro tempo de c.137. Agrupamentos dos gestos D, E e F voltarão a aparecer em maior volume a partir de c. 279 até o fim da Sonata.

Observando os diversos agrupamentos dos gestos D, E e F, é possível mapear certas recorrências no que diz respeito à função estrutural que cada um deles desempenha dentro do conjunto. $\mathrm{O}$ gesto $\mathrm{D}$, com seu perfil direcional, tende a assumir a função de impulso do movimento global do agrupamento e, por isso, costuma ser mais curto (em número de notas) e anteceder os demais gestos. $\mathrm{O}$ gesto $\mathrm{E}$ é apresentado geralmente após do gesto $\mathrm{D}$ e, por conta do seu perfil ziguezagueante, tende a expandir e adensar o movimento geral do agrupamento. O gesto $\mathrm{F}$, apresentado em geral no fim do agrupamento, desempenha um papel de "ponto de chegada", tanto por se fixar sobre uma única nota quanto por ser o gesto mais longo (em número de notas). $\mathrm{O}$ gesto $\mathrm{F}$ pode ser compreendido como uma retenção ou diluição do movimento global de cada agrupamento. A figura a seguir mostra um exemplo desse tipo de agrupamento:

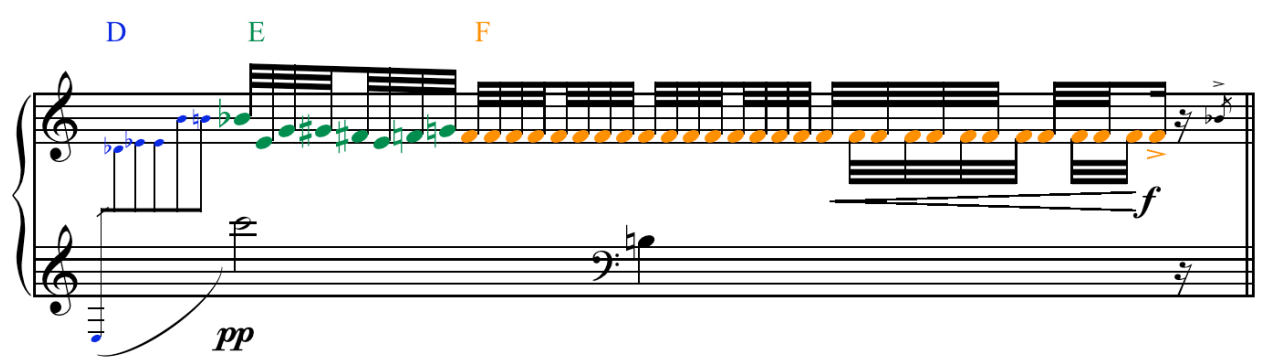

Fig. $67-(\mathrm{D}+\mathrm{E}+\mathrm{F})$ : agrupamento dos gesto D, E e F, c.79.

Porém, os gestos D, E e F também apresentam alguns agrupamentos com configurações diferentes dessa anteriormente comenta. Entre c.84 e c.86, por exemplo, o 
agrupamento é iniciado com o gesto $\mathrm{D}$, tem continuidade com o gesto $\mathrm{E}$ e, finalmente, segue para o gesto F. Porém, após o gesto F, o gesto E é novamente inserido provocando uma mudança de sentido musical do agrupamento que acaba permanecendo com sua conclusão em suspenso. Dessa maneira, após estabelecer certas funções musicais a cada um dos três gestos, Berio pode jogar com a memória do ouvinte subvertendo essa ordenação inicial. A partir de c.88 passa a se configurar um novo agrupamento entre os gestos D, E e F. Esse novo agrupamento pode ser bem exemplificado pelo trecho compreendido entre c.118 e c.120 (Fig. 68). Esse novo agrupamento se consolida principalmente nos momentos onde o gesto $\mathrm{F}$ passa a ser mais instável, isto é, quando ele começa a transitar mais rapidamente de uma nota a outra (Fig. 66). No exemplo a seguir é possível verificar que, nesse novo tipo de agrupamento, o gesto D mantém sua função de impulso (ainda que com perfil descendente) enquanto o gesto E passa a assumir o papel de "elemento modulatório", conduzindo o gesto $\mathrm{F}$ a diferentes notas. É justamente o gesto E que possibilitará a transição entre as diferentes transposições do gesto F. No exemplo a seguir é possível ainda verificar uma breve sobreposição dos gestos $\mathrm{F}$ (m.d.), D e E (m.e.), além de uma sobreposição entre o agrupamento formado pelos gestos D, E e F (m.d) e o gesto G (m.e.).
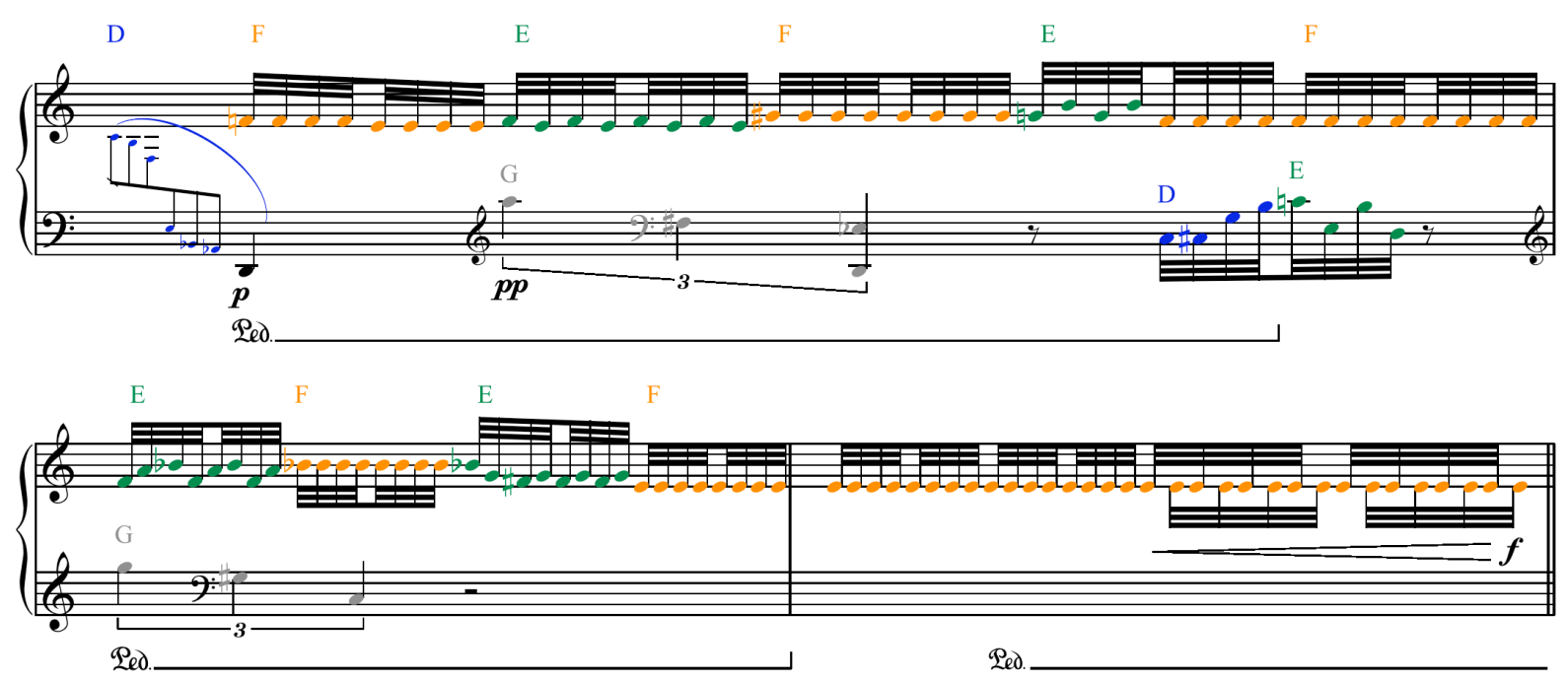

Fig. $68-[(D+E+F) / G]: \underline{\text { agrupamento dos gestos } D, E \text { e F, e sobreposição }}$ desse agrupamento ao gesto G, c.118 a c.120. 
história energética do gesto $\mathrm{G}$

Na parte inicial da Sonata o gesto G apresentava sobreposições apenas ao gesto Z. O contato com diferentes gestos passará a acontecer especialmente a partir de c.79, quando alguns fragmentos do gesto $\mathrm{G}$ começam a ser articulados em sobreposição aos agrupamentos formados pelos gestos D, E e F. Poucos compassos adiante (a partir de c.111), já é possível mapear com bastante clareza o gesto $\mathrm{G}$, em sua totalidade, em sobreposição aos gestos $\mathrm{E}$ e F. O exemplo a seguir ilustra essa sobreposição:


Fig. $69-[(\mathrm{E}+\mathrm{F}) / \mathrm{G}]$ : agrupamento dos gestos E e F e sobreposição desse grupo ao gesto $\mathrm{G}, \mathrm{c} .111$ a c.116.

Essa configuração dos gestos D, E, F e G se estende por um grande trecho, até o início de c.137. Em seguida, segue um longo período de ausência do gesto G (com uma breve 
reaparição entre c.192 e c.195). Já entre c.242 e c.249, podemos observar o retorno do gesto $\mathrm{G}$, porém com uma significativa transformação em sua figura. Como vimos no Capítulo II, no Quadro Comparativo A (ver Fig. 2), os compassos 242 a 249 integram um trecho que não possui correlação com Interlinea. Porém, o que temos nesses compassos é justamente o gesto G, com uma figura diferente. Nesse trecho, o gesto $G$ não aparece mais sobre figuras que compõem uma espécie de linha melódica, mas sim sobre figuras que compõem uma linha verticalizada, isto é, um conjunto de blocos harmônicos que desenham um perfil melódico. Com essa nova figura, o gesto G se aproxima de certa maneira do gesto B, que apresenta blocos verticais com longas durações. Assim, aqui também podemos considerar o surgimento de uma nova figura a partir de uma modulação entre diferentes gestos. É interessante ainda notar que, em c.241, é justamente o gesto que introduz essa nova figura do gesto G. A nova figura do gesto $\mathrm{G}$ guarda duas importantes semelhanças com àquela figura inicial apresentada entre c.26 e c.28: o ritmo regular em semínimas de tercina; e o perfil fragmentado pela distribuição em diferentes registros. $\mathrm{O}$ exemplo abaixo mostra a figura gerada pela modulação entre os gestos B e G:

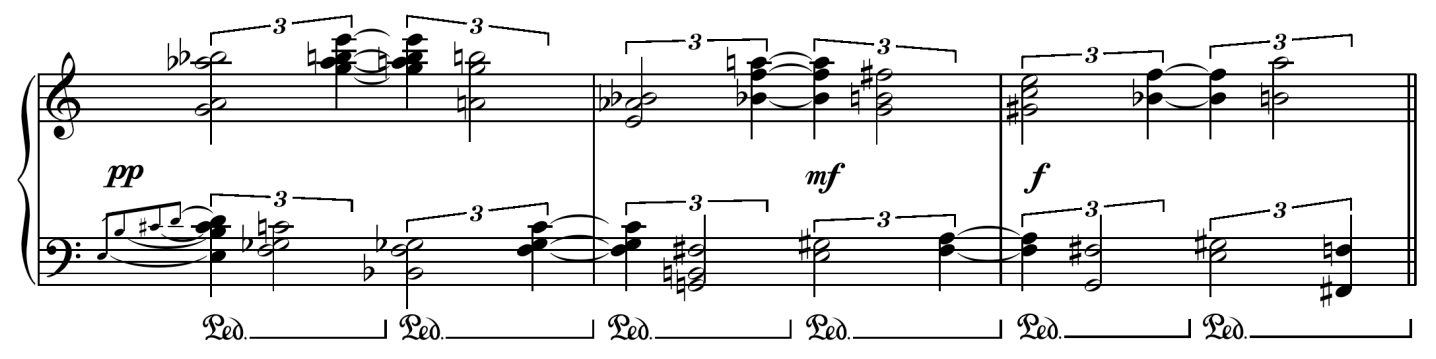

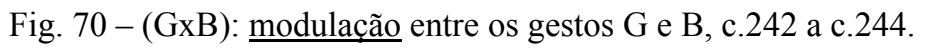

Essa transformação de um perfil de linha melódica para um perfil de blocos harmônicos ocorre de maneira gradual dentro da peça. Em diversos momentos anteriores o gesto $G$ já havia abarcado certas verticalizações da linha melódica, ainda que de forma sutil e inconstante. Esse processo pode ser verificado de maneira mais diluída em c.114, c.117 e entre c.126 e c.127, por exemplo. O gesto G voltará à sua figura inicial a partir de c.286 e estará presente até o fim da Sonata. 
No decorrer da leitura das histórias energéticas de cada gesto, observamos algumas estratégias composicionais utilizadas para relacionar os diferentes gestos entre si, provocando breves "curtos-circuitos". Nesse contexto, comentamos alguns exemplos de

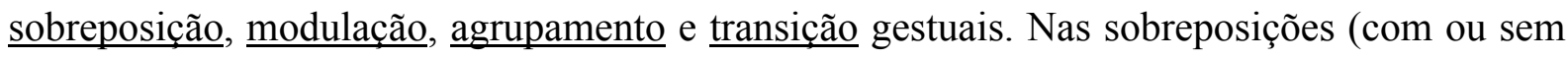
convergência rítmica), há uma confluência entre gestos distintos sem que suas características figurais próprias sejam alteradas. Vimos, a critério de exemplo, as sobreposições apresentadas logo no início da peça entre o gesto Z e os gestos A e B (Fig. 52 e Fig. 53). Vimos também um exemplo de sobreposição um pouco mais complexa, onde o gesto G aparece sobreposto a um agrupamento composto pelos gestos D, E e F (Fig. 68 e Fig. 69). Nas modulações, uma ou mais características figurais de um gesto são incorporadas por outro gesto e vice-versa, como no caso da modulação entre os gestos Z e C (Fig. 53), Z e F (Fig. 54 e Fig. 55), Z e B (Fig. 56 e Fig. 59), ou G e B (Fig. 70). Para realizar transições entre diferentes gestos Berio se aproveita de alguma característica figural em comum para que, através dela, possa realizar um deslocamento gradual de um gesto a outro. Essa característica figural em comum funciona como uma espécie de eixo entre os diferentes gestos. Vimos um exemplo bastante claro de transição entre os gestos C e E (Fig. 62). Os agrupamentos tendem a reunir gestos distintos porém que apresentem alguma característica figural em comum, como no caso do agrupamento resultante do encontro dos gestos D, E e F (Fig. 67, Fig. 68 e Fig. 69), ou dos gestos A e B (Fig. 58 e Fig. 61).

Porém é importante ainda ressaltar que nem todos os gestos passam por todos esses quatro processos mapeados. Os gestos $\mathrm{Z}$ e $\mathrm{G}$, por exemplo, tendem a se sobrepor a outros gestos, ou mesmo a modulá-los, porém não costumam operar por agrupamentos. E mesmo considerando que eles tenham uma tendência a sobreposições, não significa que eles se sobreponham a qualquer gesto, indiscriminadamente. $\mathrm{O}$ gesto $\mathrm{Z}$, por exemplo, se sobrepõe a todos os gesto com exceção do gesto $\mathrm{F}$ com o qual estabelece uma relação de modulação e não de sobreposição. Por sua vez, o gesto $G$ tende a se sobrepor na maior parte das vezes ao agrupamento formado pelos gestos D, E e F. Os gestos D, E e F apresentam um comportamento bastante distinto dos gestos $\mathrm{Z}$ e G. Eles são muito interdependentes e, no geral, costumam se agrupar compondo figuras mais longas. Porém, raros são os momentos onde esses gestos aparecem sobrepostos entre si. Há poucas ocorrências de sobreposição do gesto D aos gestos E e F (c.323), e nenhuma ocorrência de sobreposição do gesto E aos gestos D e F, por exemplo. Os gestos A e B, ainda que apareçam sobrepostos a outros gestos, 
também apresentam uma tendência a se agruparem, gerando novas figuras. Há, portanto, conexões muito exploradas na peça e outras nunca realizadas. Não se vê, por exemplo, nenhum tipo de processo que reúna os gestos $\mathrm{C}$ e G, ou os os gestos $\mathrm{D}$ e B. Isso mostra que os gestos apresentam maior ou menor permeabilidade, isto é, maior ou menor disposição a realizar conexões com outros gestos. Os gestos menos permeáveis são, portanto, mais pregnantes e mais fechados a combinações e deformações. É interessante aqui observar como se comportam os gestos $\mathrm{Z}$ e $\mathrm{C}$, que são próprios à Sonata, isto é, que não são oriundos de Interlinea. $\mathrm{O}$ gesto $\mathrm{Z}$ é o gesto mais maleável dentro da Sonata, apresentando conexões com todos os demais gestos e participando de processos de sobreposição e modulação. Por outro lado, o gesto C é o gesto menos maleável dentro da Sonata, apresentando conexões com poucos gestos e em momentos muito específicos da peça. O diagrama abaixo sintetiza as conexões que consideramos mais relevantes de serem exemplificadas e que comentamos no decorrer desse capítulo:



Fig. 71 - Diagrama de tendências e conexões mais comuns entre os oito gestos mapeados.

Seja através de sobreposições, modulações, agrupamentos ou transições, Berio coloca em operação dentro da Sonata a idéia de morfogênese, como parte integrante da noção de processo. É através da morfogênese que dois comportamentos distintos e bem delimitados podem gerar um terceiro comportamento que não estava previsto a princípio: 
Lidamos sempre com modelos, mesmo os que nós mesmos elaboramos, e o nosso trabalho consiste em ampliar o campo e o percurso das transformações até conseguir transformar, como nos contos de fadas, uma coisa em outra. Quer que eu lhe diga qual é o meu ideal de teatro? Pois bem, é pegar dois comportamentos simples e banais, como "andar debaixo da chuva" e "escrever a máquina", e encená-los de forma que eles se transformem e produzam por morfogêneses um terceiro comportamento, que não sabemos direito o que será porque nunca o vimos antes e porque é a combinação elementar de dois comportamentos banais. A fim de que isso aconteça, no teatro ou na música, os comportamentos devem ser reconhecíveis (BERIO, 1988, p.89-90).

É importante ainda notar que a Sonata não apresenta polifonias gestuais intrincadas. A riqueza do trabalho gestual na Sonata não está num jogo de simples aglomeração de diferentes gestos mas sim na idéia de que um gesto interfere em outro e que essas interferências são irreversíveis. E é dessa rede de interferências que a Sonata se faz. Assim, apesar de ser uma peça para um instrumento capaz de executar diversos acontecimentos simultâneos, Berio opta por manter sempre a percepção imediata de cada um dos gestos. De maneira geral, a peça se desenrola quase integralmente sobre uma ou duas camadas de acontecimentos simultâneos, resultando assim numa textura muito transparente que favorece a escuta das deformações geradas e sofridas por cada um deles.

Um último fator a ser demarcado e que será importante para o comentário a respeito da forma no Capítulo $\mathbf{V}$, é que os procedimentos mais complexos de agenciamento entre os gestos (transição, agrupamento e modulação) acontecem em maior volume na parte central da peça. Na parte inicial e na parte final os gestos têm sua estrutura original preservada já que os agenciamentos entre eles se concentram em jogos mais simples de sobreposição que, apesar de possibilitarem uma conexão entre diferentes gestos, não interferem em suas estruturas de maneira acentuada. As modulações realizadas na parte inicial da peça, como por exemplo aquela comentadas entre o gesto $Z$ e C (Fig. 53), são menos complexas do que aquelas realizadas na parte central, como a modulação entre os gestos Z e F (Fig. 54 e Fig. 55) que marcará a história energética do gesto $\mathrm{Z}$ de maneira irreversível, ou ainda a modulação entre os gestos G e B (Fig. 70), onde uma relação a princípio improvável - entre um gesto essencialmente melódico e outro, essencialmente harmônico - é estabelecida. Mesmo os agrupamentos realizados na parte inicial da Sonata - como aquele observado entre os gestos D, E e F (Fig. 68 e Fig. 69) - tendem a ser menos complexos do que aqueles apresentados na parte central da peça - como é o caso do agrupamento dos gestos A e B (Fig. 58 e Fig. 61) que acaba se consolidando como uma nova figura com desdobramentos próprios. 
VI. forma 
forma

A noção de processo comentada no capítulo anterior permaneceria como um componente essencial à poética de Berio até suas últimas peças. Em entrevista a Theo Muller, concedida em 1995 - cerca de quarenta anos após a composição de Nones e a esses debates que envolveram a movimentada década de 50 - Berio evidencia a relação entre processo e forma musical: "Alguns compositores estão interessados somente na música como forma. Eu estou muito mais interessado no aspecto formativo, na música como um processo" (BERIO, 1997, p. 17) ${ }^{84}$. Assim, o movimento gestual dentro da Sonata - incluindo sua estruturação inicial e o desenrolar de sua história energética - que acaba por constituir a forma musical na peça.

O Mapa Formal (Fig. 72a e Fig. 72b) a seguir apresenta uma leitura de um possível seccionamento da Sonata, conduzido pelas análises realizadas no decorrer do trabalho. Para a construção desse Mapa, levamos em conta as três estratégias composicionais abordadas nos capítulos anteriores: a relação entre os conteúdos de Interlinea e da Sonata, mostrando de que maneira o processo de reescritura em Berio também está relacionado à

84. "Some composers are just interested in music as form. I am much more interested in the formational aspect, in music as a process". 
composição da forma musical; a distribuição dos gestos na Sonata, que permite compreender as diferenças de sonoridade a cada momento, enfatizando onde a sonoridade é contínua e onde ela é interrompida por oscilações mais acentuadas de material; a compreensão de uma trajetória processual dentro da Sonata, exposta pela história energética de cada gesto, através da qual é possível verificar a estruturação de um fluxo contínuo de deformação que acaba por colocar a forma musical em movimento.

O Mapa Formal foi construído a partir do Quadro Comparativo A (Fig. 2) e, assim como ele, segue a ordenação dos compassos da Sonata, mostrando sua correlação com Interlinea. Porém, enquanto o Quadro Comparativo A (Fig. 2) mostrava de maneira pontual, compasso-a-compasso, as correlações entre os trechos da Sonata e de Interlinea, o Mapa Formal toma maior distância do objeto e apresenta uma espécie de síntese das relações entre as duas peças, agrupando os trechos em estruturas maiores.

O Mapa Formal é composto por três eixos, construídos a partir do seguinte processo: o eixo III do Mapa Formal é dedicado à correspondência entre os materiais da Sonata e de Interlinea. Os trechos da Sonata estão marcados em azul e os de Interlinea estão marcados em amarelo. Nos momentos onde ocorre a correspondência entre os materiais da Sonata e de Interlinea, os trechos aparecem marcados na cor verde. Assim, todos os trechos marcados em verde são os materiais reescritos de Interlinea dentro da Sonata.

Num segundo momento, no eixo II (em cinza), há um mapeamento sintético dos materiais (gestos) apresentados a cada momento dentro da Sonata, o que permite a realização de um primeiro seccionamento (subseções). A leitura desses materiais levou em conta não somente a análise gestual realizada no terceiro capítulo mas também a verificação do movimento processual durante o quarto capítulo, que nos permitiu relacionar cada material com um gesto de origem. Após esse primeiro seccionamento pudemos realizar agrupamentos maiores, levando em conta sonoridades mais ou menos homogêneas. Assim, o primeiro seccionamento realizado a partir da leitura dos materiais foi compreendido como subseções que se agruparam em seções mais extensas, apresentadas ainda no eixo II.

Finalmente, no eixo I (em rosa), pudemos comparar as seções encontradas anteriormente e, novamente, a partir de uma avaliação das sonoridades de cada uma delas, pudemos agrupá-las em três grandes partes mais homogêneas, encerrando assim o mapeamento formal da peça que inclui, portanto: partes - seções - subseções.

Uma característica importante incorporada ao Mapa Formal é a diagramação 
proporcional dos três eixos com relação às dimensões da Sonata. Os Quadros Comparativos A e B (Fig. 2 e Fig. 3) haviam sido construídos de maneira mais esquemática e não levavam em conta a dimensão temporal das peças. Nos Quadros Comparativos A e B (Fig. 2 e Fig. 3), um trecho de vinte compassos tinha uma representação gráfica idêntica a um trecho de dois compassos. Essa nova diagramação proposta para os eixos da Sonata no Mapa Formal permite uma visualização mais precisa da proporção entre os diferentes momentos da peça. Assim, trechos mais longos são representados por retângulos mais longos e trechos mais curtos, por retângulos mais curtos. ${ }^{85}$

85. A representação proporcional utilizada no Mapa Formal leva em conta a quantidade de compassos e não a minutagem absoluta de cada trecho. Sabendo que na Sonata as fórmulas de compasso são cambiantes, tal gráfico não pretende oferecer uma proporção precisa entre os trechos, mas sim aproximada. 


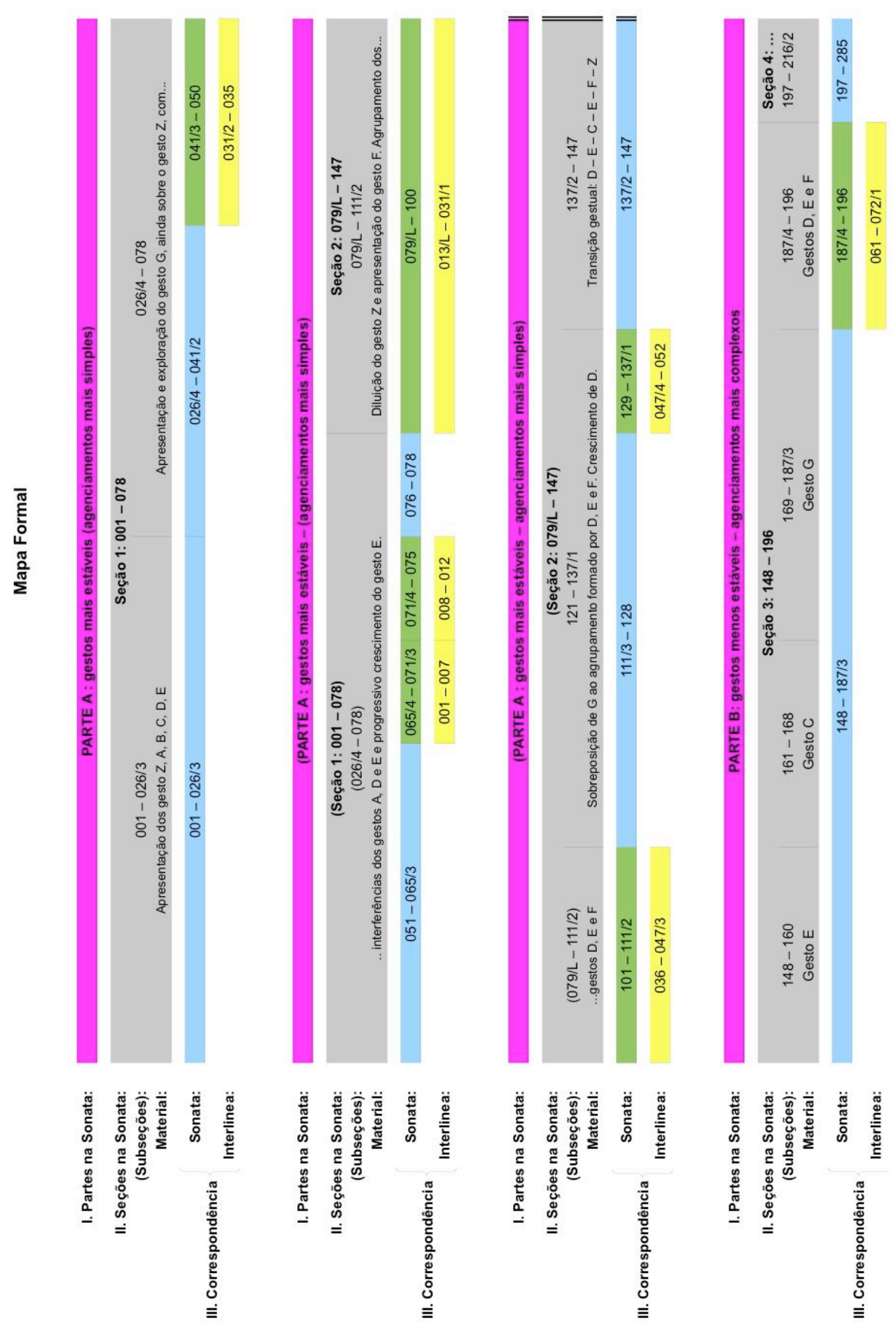

Fig. 72a - Mapa Formal (parte 1/2). 


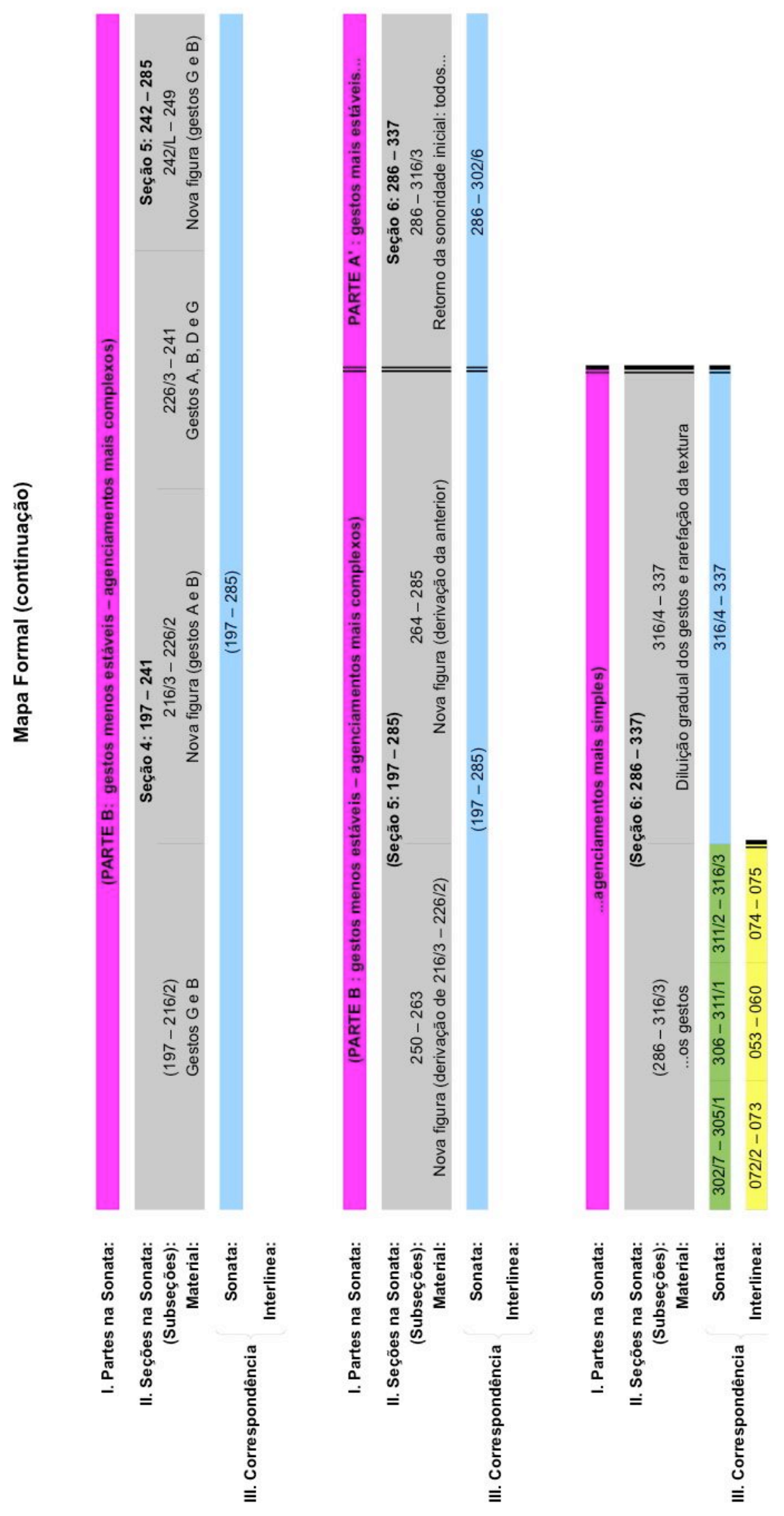

Fig. 72b - Mapa Formal (parte 2/2). 
O Mapa Formal apresenta um particionamento da Sonata em seis seções, cada uma delas divididas em subseções menores, de acordo com os materiais apresentados. Uma primeira seção pode ser delimitada entre os compassos 001 - 078. Essa seção, caracterizada por uma sonoridade bastante transparente, apresenta sete dos oito gestos que irão compor a Sonata, podendo ser subdividida em duas subseções: uma primeira entre os compassos 001 026/3, onde são apresentados os gestos Z, A, B, C, D e E, e uma segunda, entre os compasos 026/4 - 078, marcada pela ampla utilização do gesto G que, com sua textura esparsa, mantém ainda uma sonoridade similar àquela apresentada nos primeiros 26 compassos. Durante essa segunda subseção (iniciada em 026/4) da primeira seção da Sonata, o gesto G sofre interferências de diversos outros gestos, especialmente do gesto E que passa a crescer em tamanho gradativamente até que nos compassos 076/5 a 078 é ampliado em larga medida, funcionando como um impulso para uma nova seção. No compasso 079/L tem início uma

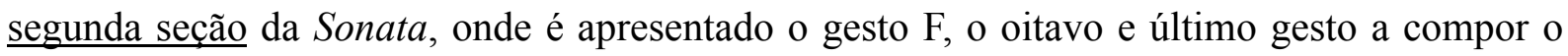
quadro de gestos iniciais da Sonata. Essa seção cria um contraste com a seção anterior na medida em que explora os gestos D, E e F quase ininterruptamente, gerando um movimento frenético e, consequentemente, uma textura mais densa, com maior índice de atividade. Também é um grande contraste nessa segunda seção a diluição do gesto $Z$ que caracterizava a sonoridade da seção anterior. Na segunda seção, o gesto F passa a assumir o papel que era cumprido inicialmente pelo gesto $\mathrm{Z}$ porém com maior mobilidade harmônica, espalhando-se por diferentes notas e não exclusivamente pela nota $\mathrm{B}, 4$. Essa segunda seção pode ser subdivida em três subseções, ainda que com sonoridades muito similares: uma primeira, entre 079/L - 121/1, marcada pela ampla utilização do agrupamento formado pelos gestos D, E e F e da sobreposição do gesto G a esse agrupamento; uma segunda, entre 121/2 - 137/1, caracterizada pelo amplo crescimento do gesto D; e uma terceira subseção, entre 137/2 - 147, marcada por um processo de transição gestual que conduzirá à seção seguinte. Essa transição funciona como uma espécie de "freio" (ainda que num primeiro momento acumule tensão para só num segundo momento dissipá-la rapidamente) para o movimento contínuo instaurado desde 079/L e é construída através de um encadeamento de gestos na seguinte ordem: D-EC-E-F-Z.

Uma terceira seção tem início no compasso 148 e se estende até o compasso 196. Essa seção pode ser subdividida em quatro subseções que se diferenciam principalmente por conta do trabalho gestual em cada uma delas. Nessas subseções é possível perceber dois tipos 
antagônicos de tratamento dos gestos: o surgimento de algumas "ilhas" em torno de um determinado gesto através de um processo de reiteração (sempre comportando deformações) e a rápida passagem de um gesto a outro, impedindo a estabilização de algum deles. A primeira subseção, 148 - 160, concentra-se na exploração do gesto E que é repetido três vezes, cada uma delas com uma deformação diferente; a subseção 161 - 168 cria uma "ilha" em torno do gesto C; já a subseção 169 - 187/3 apresenta um processo de justaposição contínua de diversos gestos (A, B, C, D e G), não se fixando sobre nenhum deles; a última subseção, 187/4 - 196 concentra-se sobre os gestos D, E e F, retomando uma correlação com Interlinea que havia estado ausente da Sonata há cerca de 50 compassos. De maneira global, essa terceira seção da Sonata (dividida em quatro subseções) preserva ainda o perfil inicial dos gestos. Apesar de todas as deformações, é possível identificar com clareza cada um dos oito gestos mapeados inicialmente. No compasso 197 tem início uma quarta seção, que apresenta deformações gestuais mais acentuadas do que as seções anteriores. Essa seção também pode ser subdividida em três subseções. A primeira delas, 197 - 216/2, composta por deformações dos gestos $\mathrm{B}$ e $\mathrm{G}$, apresenta uma textura mais esparsa, remetendo a escuta à sonoridade inicial da peça que havia sido substituída pelo movimento textural mais frenético desde 079/L. A segunda subseção, 216/3 - 226/2, concentra-se sobre uma figura nova (quasi jazz), construída gradativamente durante a peça a partir do agrupamento dos gestos A e B. A última subseção, $226 / 3$ - 241, volta a ser mais instável, não se fixando sobre nenhum gesto em especial: ela apresenta uma seqüência de fragmentos constituídos pelos gestos A, B, D e G. Uma quinta seção tem início no compasso 242 e se estende até o compasso 285. Assim como a seção anterior, esta também pode ser subdividida em três subseções. Uma primeira, 242/L - 249, é caracterizada por uma figura que, como vimos no capítulo anterior, resulta da modulação entre os gestos G e B. Uma segunda subseção, 250 - 269/2 81 retoma, de certa maneira, a sonoridade da segunda subseção da seção anterior (216/3 - 226/2, quazi jazz), porém com uma textura mais melódica do que acordal (incorporação do gesto G) e com um contraponto rítmico que lhe é peculiar. A terceira subseção, 264 - 285 é uma derivação da subseção anterior e não se estabiliza sobre qualquer gesto. Ela opera mais como um movimento de retransição para a seção seguinte, onde acontecerá o retorno dos gestos inicias da Sonata.

Uma sexta e última seção tem início em 286 e se estende até o fim da peça. Essa seção final reúne todos os gestos mapeados na Sonata e retoma a sonoridade inicial da peça (principalmente aquela apresentada entre 079/L - 147). Essa última seção pode ser 
subdividida em duas grande subseções: uma primeira entre os compassos 286 e 316/3, onde são explorados especialmente os gestos C, D, E, F e G; e uma segunda, entre os compassos $316 / 4$ e 337, onde se somam a eles os gestos A e B e onde passa a ocorrer uma diluição gradual de todos os gestos com uma conseqüente rarefação da textura nos compassos finais.

O Mapa Formal apresenta em dois momentos a inserção de uma barra dupla: primeiro entre a terceira e quarta seção e, depois, entre a sexta e a sétima. A barra dupla indica um seccionamento mais geral da Sonata, em três grandes partes: A, B e A'.

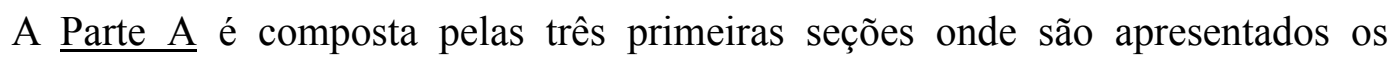
materiais básicos da Sonata, ou seja, os gestos Z, A, B, C, D, E, F e G. Especialmente nas duas primeiras seções, esses materiais sofrem deformações mais sutis, através de agenciamentos (sobreposições, modulações, principalmente) mais simples. A terceira seção já apresenta uma mobilidade e um adensamento maior, tanto pela diluição do gesto $\mathrm{Z}$ e menor presença do conjunto de gestos formado por A, B e C (que são mais pontuais), quanto pela inserção do gesto F e pela ênfase dada ao conjunto formado pelos gesto D, E, F e G (que são mais extensivos). Nessa terceira seção também podemos observar processos de transição e agrupamento, porém ainda através de agenciamentos mais simples.

$\mathrm{Na} \underline{\text { Parte B }}$, que tem início em 148, os gestos passam a sofrer deformações mais acentuadas, através de processo mais complexos de sobreposição, modulação, transição e agenciamento. A Parte B, ao contrário da Parte A, é caracterizada por sonoridades bastante heterogêneas. Como vimos, na Parte A, mesmo no particionamento das duas seções em subseções menores, a sonoridade ainda era bastante homogênea dentro de cada uma das seções, sempre caracterizada por um conjunto restrito de gestos. Assim, na Parte A, há uma sonoridade homogênea entre 001 - 079/L, e outra entre 079/L - 147, ainda que possamos verificar nuanças sutis entre cada uma das subseções. Já na Parte B, ocorrem duas situações diferentes: ou uma rápida alternância entre diferentes gestos dentro de cada uma das seções, o que gera um adensamento e uma instabilidade maior; ou um congelamento sobre um determinado gesto, criando algumas "ilhas" caracterizadas por uma determinada sonoridade, porém, por um curto período de tempo. É por isso que cada uma das três seções que compõem a parte B é particionada em subseções menores que são muito distintas. Dessa maneira, a Parte B é marcada por um constante processo de estabilização e desestabilização dos gestos.

Por fim, na Parte $\mathrm{A}^{\prime}$, iniciada em 286, há uma espécie de retorno à sonoridade inicial da peça. Os gestos tornam a aparecer de maneira similar àquela do início da Sonata, 
isto é, sem procedimentos complexos de agenciamento. É relevante ainda verificar que os diferentes procedimentos de reescritura - citação, expansão, derivação e proliferação ocorrem essencialmente nas partes A e A' da Sonata. Tudo opera como se o momento central da peça, isto é, a Parte B, fosse uma grande digressão a respeito de Interlinea que aparece preservada - ainda que reescrita - na parte inicial (principalmente a partir de 079/L) e final da Sonata. Sob essa perspectiva, os compassos iniciais da Sonata, isto é, o trecho compreendido entre 001 - 079/L, seria uma grande introdução ao material de Interlinea agregando a ela dois novos gestos, C e Z, que são próprios à Sonata.

Dessa maneira, a Sonata delineia uma espécie de estrutura tripartite e aqui nos deparamos com uma tensão no âmbito formal. Ao lado de uma estrutura ternária, convive um movimento processual contínuo que confere à Sonata um caráter quase improvisatório. Como vimos, não há contrastes acentuados do material. Os gestos apresentados desde o início impregnam a peça em sua totalidade: através da manutenção e da modificações de certos parâmetros, os gestos na Sonata são atualizados a cada vez que se apresentam. Vimos que na Sonata os gestos não são desenvolvidos através de um processo teleológico ou direcional, mas sim deformados e transformados através de curtos-circuitos constantes com outros gestos. Durante a Sonata, o tempo todo se escutam os mesmos gestos que, porém, são sempre outros. Portanto, na Sonata, Berio mostra que o gesto não é algo em si mas sim a reunião de suas diferentes manifestações ao longo da peça (morfogênese), isto é, eles só sobrevivem se vinculados à noção de processo. Por outro lado, por carregarem uma personalidade própria, os gestos também trazem em si a noção de unidade. Dessa tensão entre gesto e processo, surge um jogo entre permanência e impermanência inerente à constituição da forma musical da peça que, ao se valer de um movimento cambiante e constante de alternância entre gestos bem definidos, se configura como uma espécie de móbile. A noção de processo é fundamental para que esse móbile não se torne estático, amorfo, isto é, para que não se resuma ao simples embaralhamento de certas "peças". Assim, poderíamos pensar a forma musical na Sonata como uma espécie de móbile processual que comporta choques e deformações em cada uma de suas estruturas. E esse móbile processual é tensionado ainda pelo delineamento de uma estrutura tripartite, com seções e subseções que se definem através do movimento gestual dentro da peça.

Ainda uma última consideração a respeito da forma musical na Sonata seria comentar afinal o próprio título da peça. A alusão direta exposta pelo título somada a esse 
delineamento de uma estrutura tripartite $(\mathrm{A}-\mathrm{B}-\mathrm{A})$ nos remete a um esquema mais geral de forma sonata. Temos assim um primeiro momento de apresentação das idéias, um segundo momento onde essas idéias são trabalhadas com maior liberdade e, finalmente, um terceiro momento onde as idéias inicias retornam, ainda que deformadas. Porém, a estrutura tripartite não parece ser o principal motivo para o título da peça. O nome "Sonata" parece ter sido escolhido muito mais por uma potência expressiva da peça do que por conta de sua estrutura formal. Na nota de programa de estréia da Sonata, Berio diz:

Todas as Sonatas, independente de que época e de qual lugar, iniciam e desenvolvem, sempre e em todos os casos, um diálogo entre continuidade e descontinuidade, entre o simples e o complexo, entre presença e ausência. Na minha Sonata - escrita em 2001 e dedicada a Reinhold Brinkmann - esse diálogo está certamente presente, mas sua distribuição no tempo, isto é, sua sintaxe, é indiferente à natureza dos seus próprios caracteres expressivos. (BERIO, 2001 apud BRINKMANN in LUCCHESINI, 2007) ${ }^{86}$.

Essa leitura de Berio a respeito da forma sonata possibilita, após nossas análises, arriscarmos alguns paralelos. As idéias de continuidade e descontinuidade, por exemplo, são bastante claras na oposição entre os gestos mais ligados à noção de permanência (gestos $\mathrm{Z}$ e F) e os gestos mais voláteis (todos os demais); a distinção entre simplicidade e complexidade também pode ser relacionada aos diferentes recursos de agenciamento gestual que, como vimos, tendem a se tornar mais complexos na parte central da peça; a idéia de presença e ausência também pode ser relacionada com o movimento gestual global da peça, como por exemplo com relação aos gestos $Z$ e F cuja permanência caracteriza as partes A e A' e cuja diluição (ou instabilidade) é notável na parte B. Quando Berio diz que a distribuição desse diálogo no tempo é indiferente à natureza dos seus próprios caracteres expressivos, ele aponta que tal estratégia permeia a peça em todos os seus níveis, desde a micro à macro-estrutura. $\mathrm{A}$ Sonata mantém, em todos os níveis, um diálogo constante entre estruturas complementares: gestos curtos/longos, blocos verticais/linhas horizontais, estaticidade/direcionalidade harmônica, ritmos regulares/irregulares, seção homogênea/heterogênea etc.

86. "All Sonatas, no matter of which time and from which place, initiate and develop, always and in every case, a dialogue between continuity and discontinuance, between the simple and the complex, between presence and absence. In my Sonata - written in 2001 and dedicated to Reinhold Brinkmann - that dialogue is certainly present, but its distribution over time, i.e., its syntax, is indifferent to the nature of its own expressive characters". 
considerações finais 


\section{considerações finais}

O primeiro capítulo do nosso trabalho foi dedicado ao comentário da noção de obra aberta e de alguns de seus desdobramentos dentro do pensamento composicional de Luciano Berio. Imersos nessa poética de abertura, selecionamos três estratégias composicionais características desse compositor - reescritura, gesto e processo - que foram trabalhadas nos capítulos seguintes.

No segundo capítulo abordamos a noção de reescritura em Berio e realizamos uma análise comparativa entre a Sonata e Interlinea. Vimos que Interlinea está contida em sua totalidade na Sonata, se espalhando dentro dela de diferentes maneiras. Nesse contexto, comentamos quatro recursos utilizados por Berio durante o processo de reescritura: citação, ampliação, derivação e proliferação.

No terceiro capítulo comentamos a noção de gesto em Berio. Vimos como a idéia de gesto aparece para Berio como elemento central da expressão musical, sendo inerente a ela a tensão existente entre fechamento e abertura. A necessidade de estabelecer um jogo permanente de construção e desconstrução dos gestos no interior das peças confere a eles um caráter processual. Nas análises realizadas nesse capítulo, vimos como a Sonata é construída a partir de um número limitado de oito gestos. Durante o comentário de cada um desses gestos 
buscamos mapear semelhanças e diferenças entre eles, observando com maior detalhe a constituição do material pré-composicional da Sonata. Por conta da especificidade do assunto, optamos por comentar o tratamento rítmico e harmônico desses gestos num capítulo separado, onde pudemos observar com maior detalhe alguns aspectos figurais mais relevantes de cada um deles.

No quinto capítulo abordamos a noção de processo em Berio. Em nossas análises, vimos como os oito gestos mapeados no terceiro capítulo se deformam e são deformados através de diversos curtos-circuitos. Para verificar o caráter processual desses gestos, nos dedicamos a observar o que chamamos de história energética de cada um deles. No decorrer da leitura dessas histórias energéticas observamos algumas estratégias composicionais utilizadas para relacionar os diferentes gestos: sobreposição, modulação, agrupamento e transição gestuais.

No sexto e último capítulo, realizamos uma leitura de possíveis seccionamentos dentro da Sonata a partir das análises realizadas nos capítulos anteriores. O intuito não foi o de conduzir a análise a uma estrutura formal congelada, mas sim demonstrar de que maneira a forma musical na Sonata acaba sendo construída e exposta a partir do movimento de seus próprios materiais.

Apesar de inteiramente dedicado à análise musical, esse trabalho foi conduzido por um olhar de compositora sobre a obra de Berio. Minha motivação durante todo o trabalho foi tentar compreender algumas estratégias composicionais de Berio que revelassem de certa maneira questões a respeito da poética desse compositor cuja música me afeta. Nesse momento de conclusão da pesquisa, percebo que todo o trabalho for norteado pela idéia de que a poética de Berio lida com um jogo de tensões (dramaticidade) em diferentes níveis da composição musical. Por isso, no primeiro tópico abordado, isto é, no capítulo referente à noção de obra aberta, comentei como a poética da abertura sobrevive somente em tensão com a idéia de uma estrutura bem delimitada. Percebi, assim, a tensão entre abertura e fechamento movimentando o conceito de obra aberta. Num segundo momento, trabalhei com a idéia de reescritura que lida com a tensão entre o material de origem e o material reescrito. O material anterior é relido em novo contexto e nesse jogo de tensões entre o antigo e o novo as duas 
peças são transformadas. As peças não deixam de ter sua autonomia porém se abrem a um diálogo expressivo. Em seguida passei a pesquisar a tensão própria à noção de gesto musical. Primeiramente, no terceiro capítulo, tratei de observar seu aspecto mais fechado, isto é, sua personalidade sendo definida a partir de certas recorrências. No quarto capítulo, vi de que maneira esse gestos eram tensionados pela noção de processo, se abrindo e se deformando gradualmente. Finalmente, no último capítulo, comentei ainda a tensão entre o aspecto processual da Sonata e o delineamento de uma estrutura formal mais fechada, resultante do próprio movimento gestual dentro da peça. A imagem de um móbile - cujas peças são os gestos - modulado pela noção de processo e tensionado pelo delineamento de uma estrutura formal bem delimitada, me remeteu de volta ao ponto de partida desse trabalho: a noção de obra aberta. Assim, percebi que é do jogo de tensões entre Interlinea e a Sonata, entre gesto e processo e entre processo e forma que surgem os motores expressivos da Sonata.

O estudo de algumas estratégicas composicionais de Luciano Berio coincidiu com a composição de três peças: Círculos (2009), para 8 instrumentistas, Do livro dos seres imaginários (2010), para piano solo, e Lan (2011, em desenvolvimento), para 4 instrumentistas. Nessas três peças, ainda que eu não tenha me reportado intencionalmente à música de Berio, posso hoje perceber algumas interferências desse estudo. Ao término desse trabalho, ao concluir - e finalmente entender um pouco melhor - o meu tema de pesquisa, percebo que há uma forte ressonância da poética de Berio nas minhas peças; ou, o contrário: uma forte ressonância da minha escrita na leitura que faço da música de Berio. Em Círculos, arrisquei-me a trabalhar com um ostinato durante grande parte da peça. É curioso saber que quando comecei a compor essa peça, no início de 2009, ainda não conhecia a Sonata per pianoforte de Berio, que descobri somente alguns meses depois e que imediatamente identifiquei como a peça adequada para conduzir esse trabalho. A história de Círculos é um jogo de tensão constante entre esse ostinato e os elementos que o cercam até que ele sucumbe definitivamente a um movimento textural que acaba por diluir a peça. Em Do livro dos seres imaginários, escrita no ano passado, trabalhei muito sobre a idéia de gesto. Essa peça é na verdade a reunião de quatro peças curtas para piano, inspiradas em textos homônimos de Jorge Luis Borges: Kami, Odradek, Shang Yang e Haokah. Cada uma delas se concentra num universo sonoro bem delimitado e apresenta uma coleção de gestos bastante restrita. Aqui percebo que a tensão entre gesto e processo foi trabalhada de maneira mais refinada do que em Círculos. As peças, de fato muito gestuais, são como um mergulho num determinado som, 
ou num determinado comportamento, que não se dilui, apenas se deforma. É um estar no mesmo lugar o tempo todo, porém sempre se movimentando. Em Lan, que devo terminar dentro de um mês, há uma amplificação dessa idéia trabalhada em Do livro dos seres imaginários. A peça é mais textural do que gestual mas se concentra sobre a mesma tensão entre permanência e impermanência, buscando a escuta concentrada sobre uma mesma sonoridade que é sempre outra.

No âmbito acadêmico, para o projeto de doutorado, pretendo travar um diálogo entre a música de Luciano Berio e a música contemporânea brasileira, a partir do estudo da obra de alguns compositores nos quais percebo fortes ressonâncias de Berio. Nesse contexto, talvez possa também incorporar um comentário mais detalhado acerca de algumas das minhas peças, aproximando de certa maneira o trabalho de análise ao trabalho de composição. 
bibliografia 


\section{bibliografia de referência (obras citadas)}

BERIO, Luciano. Berio: Two Interviews with Rosanna Dalmonte and Bálint András Varga. Tradução e edição de David Osmond-Smith. New York, Marion Boyars, 1985.

. Du geste et de Piazza Carità. In: Contrechamps, n 1 (1983a), pp. 41-45.

. Entrevista sobre a música contemporânea. Entrevista realizada por Rossana

Dalmonte. Rio de Janeiro, Civilização Brasileira, 1988.

. Music is not a solitary act: conversation with Luciano Berio. Entrevista realizda por Theo Muller. In: Tempo - A Quarterly Review of Modern Music, nº 199 (1997), pp. 16-20.

. Remembering the Future. Cambridge, MA, Harvard University Press, 2006.

BRINKMANN, Reinhold. A note from the Sonata's dedicatee. Texto publicado em encarte de CD. In: LUCCHESINI, Andrea. Luciano BERIO - Piano Music. Gravado entre OutNov/2004 - Firenze (Itália). Avie Records, 2007 - AV2104.

Luciano Berio's Sonata per pianoforte solo or The disclosures of a sketch page. In: Essays in honor of László Somfai on his $70^{\text {th }}$ Birthday: studies in the sources and the interpretation of music. Edited by Lásló Vikárius and Vera Lampert. Oxford, Scarecrow Press, 2005 .

CAMPOS, Augusto de; CAMPOS, Haroldo de. Panaroma do Finnegans Wake. São Paulo, Perspectiva, 1971.

CASTELLANI, Felipe Merker. Uma abordagem sobre a noção de gesto musical nas poéticas de Luciano Berio e Brian Ferneyhough. Dissertação de Mestrado. Campinas, Unicamp, 2010.

COURTOT, Francis. Brian Ferneyhough: Figures et dialogues. Paris, Harmattan, 2009.

ECO, Umberto. Obra aberta: Forma e Indeterminação nas Poéticas Contemporâneas. São Paulo, Ed. Perspectiva, 1976.

FERNEYHOUGH, Brian. Form-Figure-Style: An intermediate assessment. In: Perspectives of New Music, vol. 31, nº 1 (1993a), pp.33-40.

. Il tempo della figura. In: Perspectives of New Music vol. 31, $\mathrm{n}^{\circ} 1$ (1993b), pp.10-19.

FERRAZ, Silvio. A fórmula da reescritura. In: Anais do III Seminário Música Ciência e Tecnologia - Sonologia (2008), pp. 41-51.

$\overline{\text { Anppom (2007). }}$

De Tinnitus a Itinerários do Curvelo. In: Anais do XVII Congresso da 
EDUC, 1998.

. Música e repetição: a diferença na composição contemporânea. São Paulo,

FOLIO, Cynthia; BRINKMAN, Alexander R. Rhythm and timing in the two versions of Berio's Sequenza I for flute solo: psychological and musical differences in performance. In: HALFYARD, Janet (Ed.). Berio's Sequenzas: essays on performance, composition and analysis. Burlington, Ashgate, 2007.

HICKS, Michael. Exorcism and Epiphany: Luciano Berio's Nones. Perspectives of New Music, vol. 27, $\mathrm{n}^{\circ} 2$, pp. 252-268, 1989.

JOYCE, James. Finnegans wake. São Paulo, Atelie Editorial, 2004.

KOZU, Fernando Hiroki. A complexidade, a figura e o ritmo no pensamento composicional de Brian Ferneyhough. In: Anais do V Fórum CLM, São Paulo, ECA/USP, 2002, pp. 45-57.

A complexidade em Brian Ferneyhough: aspectos de comunicação e inteligibilidade musical. Dissertação de mestrado. São Paulo, PUC, 2003.

LLOYD, Llewelyn S; RASTALL, Richard. Pitch nomenclature (verbete). In: SADIE, Stanley (Ed.). The New Grove Dictionary of Music and Musicians. New York, Oxford University Press, 2001, 2 ed. Vol. 19, pp. $804-807$.

LUCCHESINI, Andrea. Luciano Berio: Piano Music. Texto em encarte de CD. Avie Records, 2007 - 1 CD: AV2104.

MENEZES, Florivaldo. Luciano Berio et la phonologie. Frankfurt, Peter Lang, 1993.

OSMOND-SMITH, David. Berio. New York, Oxford University Press, 1991.

178.

. Here comes nobody. In: Cambridge Opera Journal, vol. 12, nº 2 (2000), 163. Joyce, Berio e l'art de l'explosition. In: Contrechamps, $\mathrm{n}^{\circ} 1$ (1983), pp. 83-

89.

. Playing on Words: a Guide to Luciano Berio's Sinfonia. Royal Musical Association Monographs Series, vol. 1. London, Royal Musical Association, 1985a.

PENHA, Gustavo. Reescrituras nas música dos séculos XX e XXI. Dissertação de Mestrado. Campinas, Unicamp, 2010.

ROBERTS, PAUL. The Chemins Series. In: HALFYARD, Janet (Ed.). Berio's Sequenzas: essays on performance, composition and analysis. Burlington, Ashgate, 2007.

SCHNAPPER, Laure. Ostinato (verbete). In: SADIE, Stanley (Ed.). The New Grove Dictionary of Music and Musicians. New York, Oxford University Press, 2001, 2 ed. Vol. 18, pp. 782-785. 
STOIANOVA, Ivanka. Luciano Berio: chemins en musique. Paris, La Revue Musicale ${ }^{\circ}$ 375-376-377, 1985.

VARÈSE, Edgard. The Liberation of Sound. Tradução e edição de Chou Wen Chung. In: Perspectives of New Music, vol. 5, $\mathrm{n}^{\circ} 1$ (1966), pp. 11-19.

VENN, Edward. Proliferations and limitations: Berio's reworking of the Sequenzas. In: HALFYARD, Janet (Ed.). Berio's Sequenzas: essays on performance, composition and analysis. Burlington, Ashgate, 2007.

XENAKIS, Iannis. Kéleütha (écrits). Paris, L'Arche, 1994.

\section{partituras de referência \\ (obras comentadas)}

BERIO, Luciano. Cinque Variazioni per pianoforte. Edizioni Suvini Zerboni (1969) S5119Z.

. Chemins II su sequenza VI. Universal Edition (1972) - UE13740.

. Epifanie. Universal Edition (1969) - UE13217.

. Interlinea per pianoforte solo. Universal Edition (2000) - UE31519.

. Nones, per orchestra. Edizioni Suvini Zerboni (1955) - S5203Z.

Edition (1974) - UE15908f.

. "Poins on a cruve to find...", for piano and 23 instruments. Universal . Sequenza per flauto solo. Edizioni Suvini Zerboni (1958) - S5531Z.

. Sequenza I per flauto solo. Universal Edition (1992) - UE19957.

. Sequenza IV, for piano. Universal Edition (1967) - UE 13724mi.

. Sequenza VI per viola sola. Universal Edition (1970) - UE13726.

. Sequenza VIII per violino solo. Universal Edition (1977) - UE15990.

. Six Encores pour piano. Universal Edition (1990) - UE33013.

. Sonata per pianoforte solo. Universal Edition (2001) - UE 31873.

RAVEL, Maurice. Le Gibet, Gaspard de la nuit. Durand \& Fils (1909). 


\section{gravações de referência} (obras comentadas)

ARDEN, David. Luciano Berio: The complete work for solo piano. Gravado em Ago/1996 Tanglewood, Massachusetts (EUA). New Albion Record, 1997 - 1 CD: NA089.

BERIO, Luciano; BERBERIAN, Cathy et al. Luciano Berio: Epifanie, Folksongs et al. RCA Records, 1972 - 2 LP's: RK11530.

BERIO, Luciano; BOULEZ, Pierre; London Symphony Orchestra et al. World-Premiere Recordings: Luciano Berio: Nones et al. RCA Records, 1976 - 1 LP: ARL1-1674.

BOULEZ, Pierre; Ensemble Intercontemporain. Luciano Berio: Corale, Chemins II \& IV et al. Gravado em Abr/1989 - Paris (França). Sony, 1990 - 1 CD: SK45862.

HIND, Rolf. Notes for Pierre. Edição promocional. Gravação em CD não comercial realizada pela BBC Radio 3, do concerto em homenagem ao $75^{\circ}$ aniversário de Pierre Boulez realizado em Mar/2000 - Royal Festival Hall/Queen Elizabeth Hall, London (Inglaterra).

INTERCONTEMPORAIN, Ensemble et al. Luciano Berio: Sequenzas. Gravado entre Out/1994 e Jul/1997 - Paris (França). Deutsche Grammophon, 1998 - 3 CD's: 457 038-2.

LUCCHESINI, Andrea. Luciano Berio: Piano Music. Gravado entre Out-Nov/2004 - Firenze (Itália). Avie Records, 2007 - 1 CD: AV2104.

SCHLIMÉ, Francesco Tristano. Luciano Berio: Complete piano works. Gravado em Fev/2005 - Orleans (França). Sisyphe, 2005 - 1 CD: Sisyphe005.

\section{bibliografia auxiliar}

ALBÈRA, Philippe. Introduction aux neuf Sequenzas. In: Contrechamps, n 1 (1983b), pp. 90-122.

ALDROVANDI, Leonardo. Gesto na criação musical atual: corpo e escuta. Dissertação de mestrado. São Paulo, PUC, 2000.

BERIO, Luciano. Aspect d'um artisanat formel. In: Contrechamps, nº 1 (1983b), pp. 10-23.

Entreiten avec Luciano Berio. Entrevista realizada por Michel Philippot. In: La Revue Musicale, $\mathrm{n}^{\circ}$ 265-266 (1968).

Forme. In: Contrechamps, nº 1 (1983c), pp. 36-40.

pp. 46-48.

. Meditiation sur un cheval de douze sons. In: Contrechamps, $\mathrm{n}^{\circ} 1$ (1983b), 
BITENSKY, Laurence. Multiplicity and the music of Luciano Berio: an introduction to critical and analytical issues. Tese de doutorado. New York, Cornell University, 1995.

BORGES. Jorge Luis. Ficções. São Paulo, Companhia das Letras, 2007.

BOULEZ, Pierre. A música hoje. São Paulo, Perspectiva, 2002.

CALVINO, Ítalo. Seis propostas para o próximo milênio. São Paulo, Companhia das Letras, 1990.

CARDASSI, L. Sequenza IV de Luciano Berio: estratégias de aprendizagem e performance. In: Per Musi, no 14 (2006), pp. 44 - 56.

CAVALCANTI, Maria Di e PITOMBEIRA, Liduino. A revisão notacional da Sequenza I para flauta solo de Berio e suas implicações interpretativas. In: Revista Opus, vol. 13, $\mathrm{n}^{\mathrm{o}} 2$ (2007), pp. 129-140.

COOK, Nicholas. A guide to musical analysis. New York, W. W. Norton \& Company, 1987.

COSTA, Rogério Luiz Moraes. O músico enquanto meio e os territórios da livre improvisação. Tese de doutorado. São Paulo, PUC, 2003.

ECO, Umberto. Eco in ascolto. In: Contemporary Music Review, nº 5 (1989), pp. 1-8.

FERNEYHOUGH, Brian. Brian Ferneyhough: Collected Writings. Amsterdan: Harwood, 1998.

pp.20-30.

. The tactility of time. In: Perspectives of New Music, vol. 31, $\mathrm{n}^{\circ} 1$ (1993c),

FERRAZ, Silvio. Diferença e repetição: a polifonia simulada na Sequenza VII para oboé de Luciano Berio. In: Cadernos de Estudo: Análise Musical, nº1. São Paulo, Atravéz, 1989.

. Livro das Sonoridades. Rio de Janeiro, 7 Letras, 2005.

. Semiótica Peirceana e música: mais uma aproximação. In: Opus, Rio de Janeiro, vol. 4, no 4 (1997), pp. 62-79.

GOUVEIA, Horácio de Oliveira Caldas. Os Jogos (Játékok) de György Kurtág para piano: corpo e gesto numa perspectiva lúdica. Tese de doutorado. São Paulo, USP, 2010.

HALFYARD, Janet (Ed.). Berio's Sequenzas: essays on performance, composition and analysis. Burlington, Ashgate, 2007.

$1 \mathrm{q}$

HATTEN, Robert. Interpretating musical gestures, topics and tropes: Mozart, Beethoven, Schubert. Bloomington, Indiana University Press, 2004.

IAZZETTA, Fernando. Meaning in Musical Gesture. In: BATTIER, Marc; WANDERLEY, 
Marcelo (Eds.). Trends in gestural Control of Music. Paris, IRCAM, 1999 (CD-ROM).

Paulo, PUC, 1996.

Sons de silício: corpos e máquinas fazendo música. Tese de doutorado. São

LEVI-STRAUSS, Claude. O Cru e o Cozido. São Paulo: Cosac \& Naify, 2004.

LIGETI, György. States, Events, Transformations. In: Perspectives of New Music, vol. 31, n 1 (1993), pp. 164-170.

MESSIAEN, Olivier. Technique de mon langage musical. Paris, Alphonse Leduc, 1966.

MURPHY, Timothy. Music After Joyce: The Post-Serial Avant-Garde. Hypermedia Joyce studies, 2/1 (1999). In: http://hjs.ff.cuni.cz/archives/v2/murphy/index.html. Acessado em $10 / 2010$.

MUSSGNUG, Florian. Writing Like Music: Luciano Berio, Umberto Eco and the New AvantGarde. In: Comparative Critical Studies (2008), vol. 5, n 1, pp. 81-97.

OSMOND-SMITH, David. Luciano Berio (verbete). In: SADIE, Stanley (Ed.). The New Grove Dictionary of Music and Musicians. New York, Oxford University Press, 2001, 2 ed. Vol. 3, pp. 350-358.

SADIE, Stanley (Ed.). The New Grove: Dictionary of music and musicians. New York, Oxford University Press, 2001, 2 ed.

SCHAEFFER, Pierre. Tratado dos objetos musicais: ensaio interdisciplinar. Brasília: Editora Universidade de Brasília, 1993.

SOUZA, André Ricardo. Ação e significação: em busca de uma definição do gesto musical. Dissertação de mestrado. São Paulo, UNESP, 2004.

STOIANOVA, Ivanka. Geste-texte-musique. Paris, Union Générale, 1978.

ZAGONEL, Bernardete. O que é gesto musical. São Paulo, Brasiliense, 1992.

ZUBEN, Paulo. Ouvir o som: aspectos de organização na música do século XX. São Paulo, Ateliê editorial, 2005.

Planos sonoros: a experiência da simultaneidade na música do século XX. Tese de doutorado. São Paulo, USP, 2009. 
catálogos

Suvini Zerboni. Disponível para consulta no website da editora: www.esz.it

Universal Edition. Disponível para consulta no website da editora: www.universaledition.com

\section{website}

CENTRO STUDI Luciano Berio. Site oficial da associação cultural Centro Studi Luciano Berio, presidida por Talia Pecker Berio. Disponível em: http://www.lucianoberio.org. Acesso contínuo durante toda a pesquisa. Último acesso para conferência das fontes em 27 de julho de 2011. 
anexos 
$\operatorname{anexo} A$

Sonata per pianoforte (2001) - partitura Universal Edition (2001) - UE 31873. 
$\operatorname{anexo} B$

Interlinea per pianoforte (2000) - partitura Universal Edition (2000) - UE31519. 
Sonata (2001) e Interlinea (2000) - gravações (CD) HIND, 2000; LUCCHESINI, 2007; SCHLIMÉ, 2005.

\section{Lista de Faixas - CD}

01. Sonata per pianoforte solo (2001)

Andrea Lucchesini, piano

02. Sonata per pianoforte solo (2001)

Francesco Tristano Schlimé, piano

03. Interlinea per pianoforte solo (2000)

Holf Hind, piano 